Prepared in cooperation with the Lower Elkhorn Natural Resources District, Nebraska Department of Environmental Quality, Nebraska Game and Parks Commission, Nebraska Department of Natural Resources, Nebraska Environmental Trust, and University of Nebraska-Lincoln

\title{
Relating Cyanobacteria and Physicochemical Water-Quality Properties in Willow Creek Lake, Nebraska, 2012-14
}

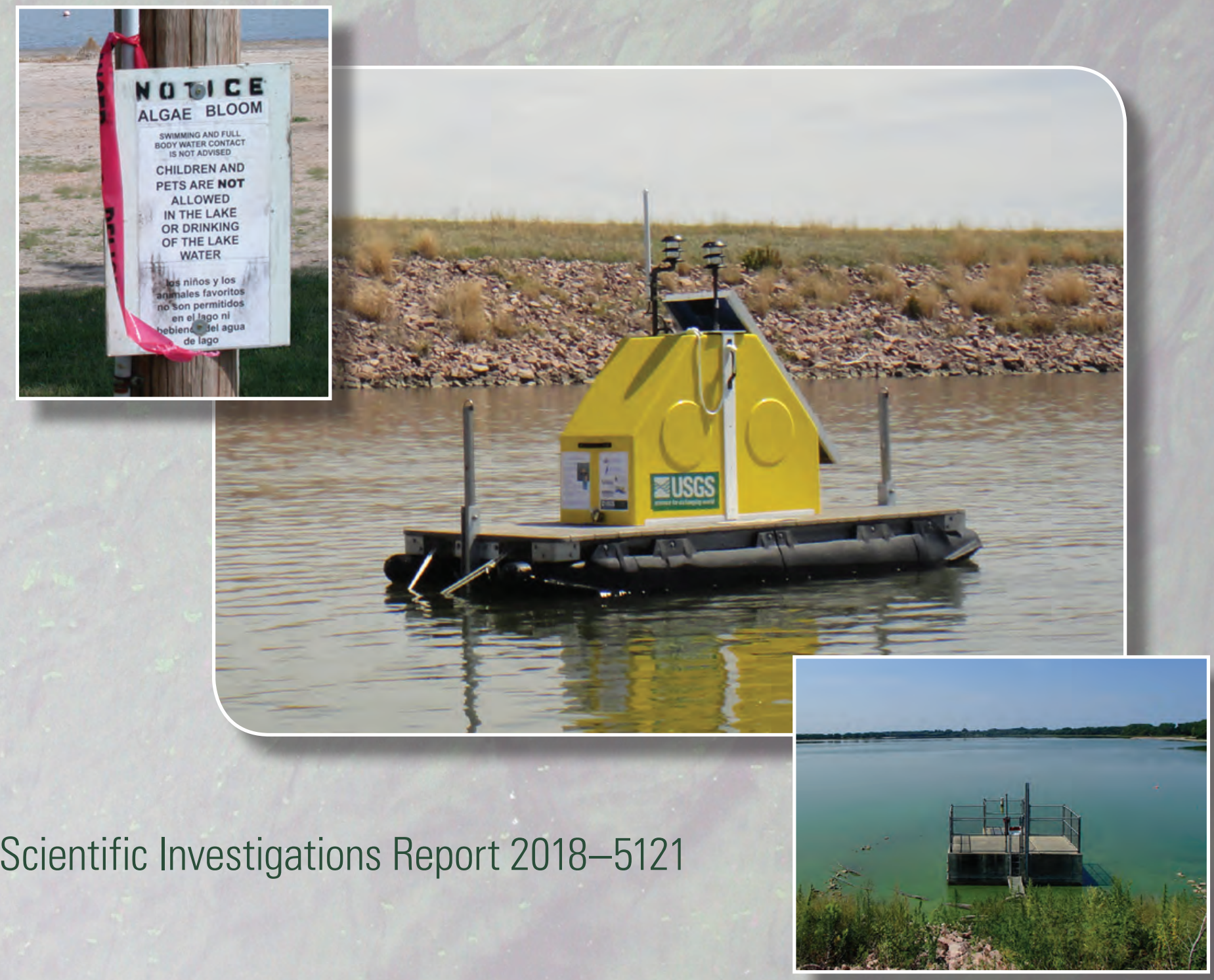

U.S. Department of the Interior U.S. Geological Survey 
Cover: Background image: Willow Creek Lake water on August 13, 2013 (Brent M. Hall, U.S. Geological Survey).

Top photograph: Elevated levels of microcystins led to the closure of the swimming beach at Willow Creek Lake on September 10, 2013 (Brent M. Hall, U.S. Geological Survey).

Middle photograph: A raft-mounted continuous water-quality monitor on Willow Creek Lake in April 2012 (David L. Rus, U.S. Geological Survey).

Lower photograph: Willow Creek Lake from the dam on August 19, 2014 (Brent M. Hall, U.S. Geological Survey).

Back photograph: By September 7, 2012, drought conditions had greatly reduced the amount of water in Willow Creek Lake (Brent M. Hall, U.S. Geological Survey). 


\section{Relating Cyanobacteria and Physico- chemical Water-Quality Properties in Willow Creek Lake, Nebraska, 2012-14}

By David L. Rus, Brent M. Hall, and Steven A. Thomas

Prepared in cooperation with the Lower Elkhorn Natural Resources District, Nebraska Department of Environmental Quality, Nebraska Game and Parks Commission, Nebraska Department of Natural Resources, Nebraska Environmental Trust, and University of Nebraska-Lincoln

Scientific Investigations Report 2018-5121 


\section{U.S. Department of the Interior \\ RYAN K. ZINKE, Secretary}

\section{U.S. Geological Survey James F. Reilly II, Director}

\section{U.S. Geological Survey, Reston, Virginia: 2018}

For more information on the USGS - the Federal source for science about the Earth, its natural and living resources, natural hazards, and the environment-visit https://www.usgs.gov or call 1-888-ASK-USGS.

For an overview of USGS information products, including maps, imagery, and publications, visit https://store.usgs.gov.

Any use of trade, firm, or product names is for descriptive purposes only and does not imply endorsement by the U.S. Government.

Although this information product, for the most part, is in the public domain, it also may contain copyrighted materials as noted in the text. Permission to reproduce copyrighted items must be secured from the copyright owner.

Suggested citation:

Rus, D.L., Hall, B.M., and Thomas, S.A., 2018, Relating cyanobacteria and physicochemical water-quality properties in Willow Creek Lake, Nebraska, 2012-14: U.S. Geological Survey Scientific Investigations Report 2018-5121, 43 p, https://doi.org/10.3133/sir20185121.

IISSN 2328-0328 (online) 


\section{Acknowledgments}

The authors thank the employees of the Lower Elkhorn Natural Resources District for assistance with project planning and data collection and Dan Sutherland of the Nebraska Game and Parks Commission for site information and logistical support. Thanks also are expressed to the Nebraska Department of Environmental Quality and the Nebraska Department of Natural Resources for assistance in data collection. 



\section{Contents}

Acknowledgments ……...................................................................................................................

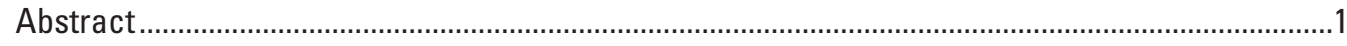







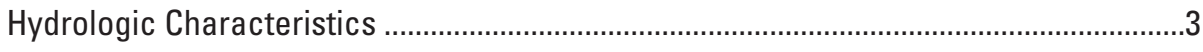

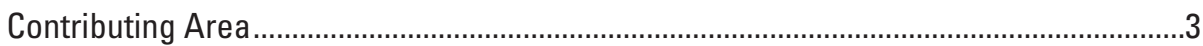



Methods

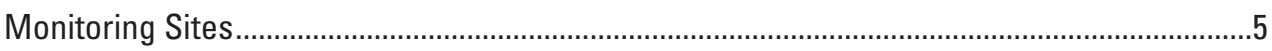

Cyanobacteria in Willow Creek Lake ...............................................................................



Algal Abundance and Community Composition Sampling .................................................

Continuous Algal Monitoring .............................................................................................

Characterization of Physicochemical Water-Quality Properties Within the Willow

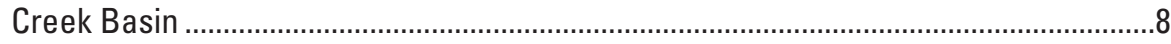

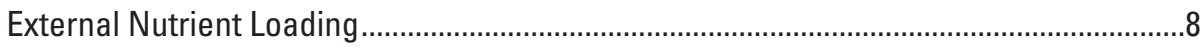

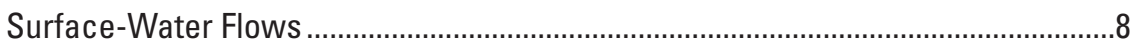

Lake Storage .............................................................................................

Evaporation, Precipitation, Net Radiation, Heat Storage, and Meteorological

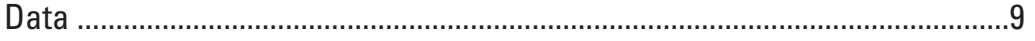

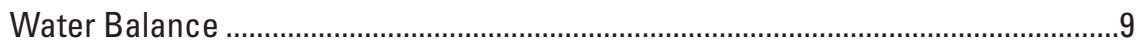



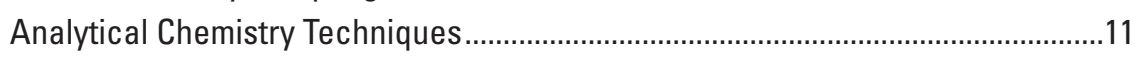



Internal Nutrient Loading ..............................................................................................11

Continuous Monitoring of Nonalgal Lake Factors..........................................................12

Relating Cyanobacteria Concentrations and Physicochemistry ............................................12

Cyanobacterial Characteristics in Willow Creek Lake ...............................................................12

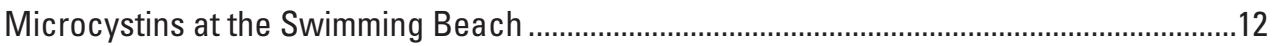

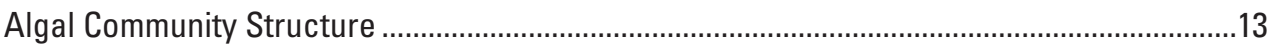

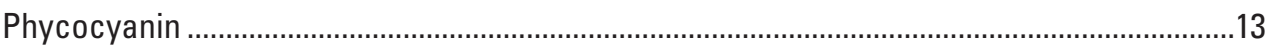

Comparing the Three Measures of Cyanobacteria ............................................................15

Physicochemical Water-Quality Properties of Willow Creek Lake ................................................16

Hydrology and External Nutrient Loading ...........................................................................16

Water Balance Components .....................................................................................16

Differences in Streamflow Characteristics Between the Sites...............................16

Lake-Groundwater Interaction ......................................................................... 19

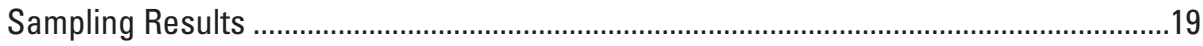

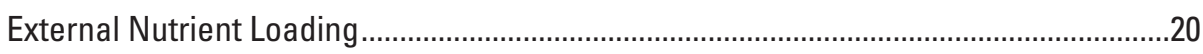

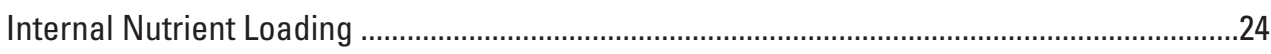

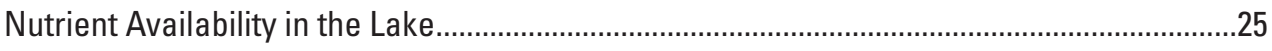

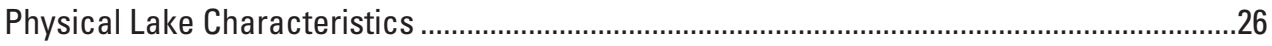

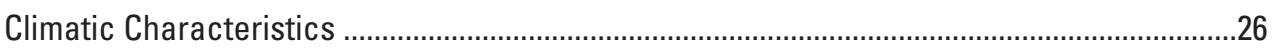




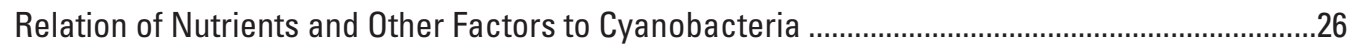

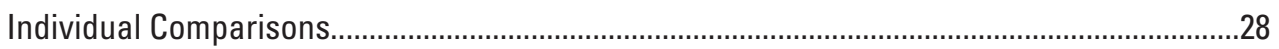

Selection of Phycocyanin Density as Primary Biotic Response......................................28

Relation of Phycocyanin Densities to Cumulative External Nutrient Loads ....................28

Seasonal Phycocyanin Densities.....................................................................................28

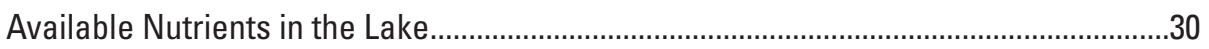

Phycocyanin Relation to Physical Lake Characteristics..................................................30

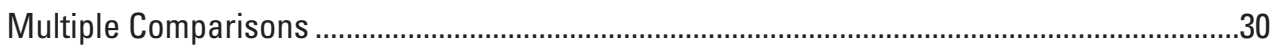

Implications for Cyanobacteria in Willow Creek Lake .............................................................3

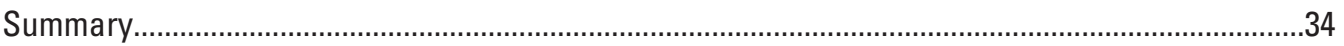

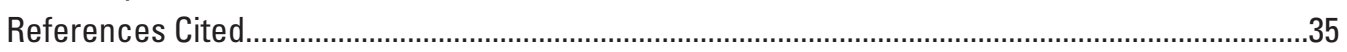

Appendix 1. Development of Stream Nutrient Load Models.....................................................42

\section{Figures}

1. Maps showing the Willow Creek Lake study area, Nebraska...

2. Graph showing weekly microcystin concentrations at the swimming beach of Willow Creek Lake.

3. Graph showing phycocyanin density 1.6 feet beneath the water surface at the profiler site of Willow Creek Lake, Nebraska, 2012-14 ..................................................14

4. Graph showing the vertical profile of phycocyanin density on August 19 and 20, 2013, at the profiler site, Willow Creek Lake, Nebraska.

5. Graphs showing intercomparisons of cyanobacteria metrics collected from the profiler and beach sites of Willow Creek Lake, 2012-14............................................16

6. Graphs showing inflows and outflows of Willow Creek Lake, Nebraska, 2012-14 .........17

7. Graphs showing the distribution of discrete samples in relation to flow-duration curves for three stream sampling sites, Nebraska, June 2012-August 2014...

8. Graphs showing external nutrient loading into Willow Creek Lake, Nebraska, 2012-14

9. Graphs showing cumulative flux of phosphate from anoxic sediment cores collected at three locations in Willow Creek Lake, Nebraska, September 19, 2013, and June 2, 2014

10. Graphs showing cumulative flux of dissolved phosphorus from anoxic sediment cores collected at three locations in Willow Creek Lake, Nebraska, September 19, 2013, and June 2, 2014

11. Graph showing the seasonal pattern of the molar ratio of dissolved inorganic nitrogen to dissolved inorganic phosphorus in Willow Creek Lake, Nebraska, 2012-14

12. Graphs showing time series of daily mean turbidity and water temperature near the water surface of Willow Creek Lake, Nebraska, 2012-14.

13. Graph showing mean monthly wind speed at Willow Creek Lake, Nebraska, 2012-14

14. Graphs showing mean biweekly phycocyanin density and microcystin concentration compared to selected physicochemical factors measured at Willow Creek Lake, Nebraska, 2012-14. 


\section{Tables}

1. Monitoring sites and corresponding data ..........................................................................

2. Analytes, methods, and laboratories for inflow and groundwater samples collected for Willow Creek Lake, 2012-14.................................................................................... 10

3. Algal community biovolumes near the swimming beach of Willow Creek Lake, Nebraska, 2013-14........................................................................................................... 14

4. Summary of phycocyanin density from 1.6 feet beneath the water surface at the profiler site of Willow Creek Lake, Nebraska, 2012-14 .................................................15

5. Water balance summaries for Willow Creek Lake, Nebraska, 2012-14...........................18

6. Chemical sampling summary for stream and groundwater sites in Willow Creek Basin, Nebraska, 2012-14 ...........................................................................................20

7. Total loading and mean annual yield into Willow Creek Lake, Nebraska, 2012-14........24

8. Nutrient release rates measured from Willow Creek Lake sediment cores,



9. Monthly averages of shallow-water values for selected water-quality parameters, Willow Creek Lake, Nebraska, May-September 2012-14 ................................................27

10. Monthly meteorological values near Willow Creek Lake, Nebraska, 2012-14 ...............29

\section{Appendix Table}

1.1 List of LOADEST models, coefficients, and performance statistics, Willow Creek Lake, Nebraska, 2012-14 


\section{Conversion Factors}

U.S. customary units to International System of Units

\begin{tabular}{|c|c|c|}
\hline Multiply & By & To obtain \\
\hline \multicolumn{3}{|c|}{ Length } \\
\hline inch (in.) & $25,400,000$ & nanometer (nm) \\
\hline inch (in.) & 25,400 & micron $(\mu \mathrm{m})$ \\
\hline inch (in.) & 25.4 & millimeter $(\mathrm{mm})$ \\
\hline inch (in.) & 2.54 & centimeter $(\mathrm{cm})$ \\
\hline foot $(\mathrm{ft})$ & 0.3048 & meter $(\mathrm{m})$ \\
\hline mile (mi) & 1.609 & kilometer $(\mathrm{km})$ \\
\hline \multicolumn{3}{|c|}{ Area } \\
\hline acre & 0.4047 & hectare (ha) \\
\hline acre & 0.004047 & square kilometer $\left(\mathrm{km}^{2}\right)$ \\
\hline square foot $\left(\mathrm{ft}^{2}\right)$ & 0.09290 & square meter $\left(\mathrm{m}^{2}\right)$ \\
\hline square mile $\left(\mathrm{mi}^{2}\right)$ & 2.590 & square kilometer $\left(\mathrm{km}^{2}\right)$ \\
\hline \multicolumn{3}{|c|}{ Volume } \\
\hline acre-foot (acre-ft) & 1,233 & cubic meter $\left(\mathrm{m}^{3}\right)$ \\
\hline acre-foot (acre-ft) & 0.001233 & cubic hectometer $\left(\mathrm{hm}^{3}\right)$ \\
\hline \multicolumn{3}{|c|}{ Flow rate } \\
\hline cubic foot per second $\left(\mathrm{ft}^{3} / \mathrm{s}\right)$ & 0.02832 & cubic meter per second $\left(\mathrm{m}^{3} / \mathrm{s}\right)$ \\
\hline mile per hour $(\mathrm{mi} / \mathrm{h})$ & 0.447 & meter per second $(\mathrm{m} / \mathrm{s})$ \\
\hline mile per hour $(\mathrm{mi} / \mathrm{h})$ & 1.609 & kilometer per hour $(\mathrm{km} / \mathrm{h})$ \\
\hline \multicolumn{3}{|c|}{ Mass } \\
\hline pound, avoirdupois (lb) & 28,350 & milligram (mg) \\
\hline pound, avoirdupois (lb) & 0.4536 & kilogram (kg) \\
\hline ton, short $(2,000 \mathrm{lb})$ & 0.9072 & megagram (Mg) \\
\hline \multicolumn{3}{|c|}{ Energy } \\
\hline kilowatthour (kWh) & 3.6 & megajoule (mJ) \\
\hline \multicolumn{3}{|c|}{ Application or release rate } \\
\hline $\begin{array}{l}\text { pounds per acre per year }([\mathrm{lb} / \\
\text { acre }] / \mathrm{yr})\end{array}$ & 1.121 & $\begin{array}{l}\text { kilograms per hectare per year } \\
\qquad([\mathrm{kg} / \mathrm{ha}] / \mathrm{yr})\end{array}$ \\
\hline
\end{tabular}

Temperature in degrees Fahrenheit $\left({ }^{\circ} \mathrm{F}\right)$ may be converted to degrees Celsius $\left({ }^{\circ} \mathrm{C}\right)$ as ${ }^{\circ} \mathrm{C}=\left({ }^{\circ} \mathrm{F}-32\right) / 1.8$.

\section{Datum}

Vertical coordinate information is referenced to the North American Vertical Datum of 1988 (NAVD 88).

Horizontal coordinate information is referenced to the North American Datum of 1983 (NAD 83). 


\section{Supplemental Information}

Specific conductance is given in microsiemens per centimeter at 25 degrees Celsius $(\mu \mathrm{S} / \mathrm{cm}$ at $\left.25^{\circ} \mathrm{C}\right)$.

Concentrations of chemical constituents in water are given either in milligrams per liter (mg/L) or micrograms per liter ( $\mu \mathrm{g} / \mathrm{L})$.

The flux of photosynthetically active radiation is given in moles of photons per square meter per day $\left(\mathrm{mol} / \mathrm{m}^{2} / \mathrm{d}\right)$.

The flux of solar radiation is given in megajoules per square meter per day $\left(\mathrm{MJ} / \mathrm{m}^{2} / \mathrm{d}\right)$.

Cumulative flux is given in milligrams per square meter $\left(\mathrm{mg} / \mathrm{m}^{2}\right)$.

Phycocyanin measurements are presented as cyanobacterial cells per milliliter (cell/mL) using a vendor-specific algorithm; however, the data are considered to be a relative metric that is useful for detecting changes in cyanobacterial biovolume rather than as an absolute metric of cell density.

Light emission is given in nanometers (nm).

Release rates are given in milligrams per square meter per day $\left(\mathrm{mg} / \mathrm{m}^{2} / \mathrm{d}\right)$.

Turbidity is given in Formazin Nephelometric Units (FNU).

Daily load is given in kilograms per day $(\mathrm{kg} / \mathrm{d})$.

Phytoplankton biovolume is given in cubic microns of algae per milliliter of water $\left(\mu \mathrm{m}^{3} / \mathrm{mL}\right)$.

A water year is the 12-month period October 1 through September 30 designated by the calendar year in which it ends. 


\section{Abbreviations}

\begin{tabular}{|c|c|}
\hline \pm & plus or minus \\
\hline${ }^{15} \mathrm{~N}$ & nitrogen-15 isotope \\
\hline${ }^{18} \mathrm{O}$ & oxygen-18 isotope \\
\hline CyanoHAB & cyanobacterial harmful algal blooms \\
\hline DIN & dissolved inorganic nitrogen \\
\hline DIN:DIP & molar ratio of DIN to DIP \\
\hline DIP & dissolved inorganic phosphorus \\
\hline$K f$ & soil erodibility factor \\
\hline $\mathrm{NH}_{4}$ & ammonium as nitrogen \\
\hline $\mathrm{NO}_{3}$ & nitrate plus nitrite as nitrogen \\
\hline NSE & Nash-Sutcliffe efficiency \\
\hline$p$-value & probability coefficient \\
\hline $\mathrm{PO}_{4}$ & phosphate as phosphorus \\
\hline$R^{2}$ & coefficient of determination \\
\hline RSD & relative standard deviation \\
\hline TDP & total dissolved phosphorus \\
\hline TKN & total Kjeldahl nitrogen \\
\hline TP & total phosphorus \\
\hline UNL & University of Nebraska-Lincoln \\
\hline USGS & U.S. Geological Survey \\
\hline
\end{tabular}




\title{
Relating Cyanobacteria and Physicochemical Water- Quality Properties in Willow Creek Lake, Nebraska, 2012-14
}

\author{
By David L. Rus, ${ }^{1}$ Brent M. Hall, ${ }^{1}$ and Steven A. Thomas ${ }^{2}$
}

\section{Abstract}

Cyanobacteria (also referred to as blue-green algae) are naturally present members of phytoplankton assemblages that may detract from beneficial uses of water because some strains produce cyanotoxins that pose health hazards to people and animals. Cyanobacteria populations observed in Willow Creek Lake during 2012 through 2014 were compared to external nutrient loading from the Willow Creek drainage basin and several other physicochemical properties within the lake, including internal nutrient loading. This report is part of a cooperative study between the U.S. Geological Survey, the Lower Elkhorn Natural Resources District, the Nebraska Department of Environmental Quality, the Nebraska Game and Parks Commission, the Nebraska Department of Natural Resources, the Nebraska Environmental Trust, and the University of Nebraska-Lincoln.

Cyanobacteria concentrations were quantified using weekly microcystin sampling, intermittent algal taxonomy, and hourly in-situ phycocyanin measurements. External and internal nutrient loads, lake water physical characteristics, and local meteorological conditions were evaluated as potential causes of cyanobacterial blooms. A water balance approach that estimated Willow Creek Lake inflow and outflow volumes identified Willow Creek as the major inflow and groundwater flux as the major outflow for the lake. Nutrient concentrations from several water sources were quantified and combined with flow volumes to compute nutrient loads during the study period.

Surface flows contributed most external nutrients to the lake, whereas lake nutrients were exported during groundwater losses. The main stem of Willow Creek accounted for most nitrate loads to the lake, whereas total Kjeldahl nitrogen, total phosphorus, and phosphate loads to the lake were more evenly distributed between Willow Creek and the North Tributary, a smaller drainage. Sediment core incubations determined internal phosphorus loading was a negligible component of the overall nutrient load to the lake.

Cyanobacterial responses were compared to nutrient loads and other external factors that could potentially affect algal growth. A series of univariate comparisons were made by plotting those factors against phycocyanin using biweekly summaries of each and a multivariate model that incorporated seasonality and cumulative nitrate loading. Although the multivariate model only incorporated cumulative nitrate, both nitrogen and phosphorus are likely contributing to cyanobacterial population growth, and management efforts may benefit from the recognition of differences in nutrient loading characteristics between the monitored basins.

\section{Introduction}

Cyanobacteria (also referred to as blue-green algae) are a natural part of the phytoplankton assemblage within a lake and often dominate communities under eutrophic (nutrient rich and highly productive) conditions. Cyanobacterial blooms can be detrimental to lakes because some cyanobacteria strains produce cyanotoxins. Cyanotoxins have been responsible for human or animal deaths in at least 27 States (Chorus and Bartram, 1999), including Nebraska (Brakhage, 2009). Cyanotoxins have several variants that can be grouped by their acute effects on human health into neurotoxins (affects the nervous system), hepatotoxins (affects the liver), and dermatoxins (affects skin and mucous membranes), although the effects of chronic exposure to cyanotoxins are less clear (Graham and others, 2008). As of 2018, the most common group of cyanotoxins are microcystins with greater than 80 known variants of the microcystin hepatotoxin. Although cyanotoxin occurrence is well documented, the factors that lead cyanobacteria to produce and release cyanotoxins is not well understood.

\footnotetext{
${ }^{1}$ U.S. Geological Survey.

${ }^{2}$ University of Nebraska-Lincoln.
} 
Lake phytoplankton communities are formed by, and react to, a complex array of ecosystem drivers including hydrological factors, nutrient availability, temperature, and light. A simplified seasonal succession of phytoplankton in a temperate, eutrophic lake can be generalized by (1) a minimal overall algal biomass in the winter, (2) a burst of diatom growth in early spring, (3) a lesser growth of green algae in late spring, (4) an overall drop in algal biomass during the transition from spring to summer, and (5) an increase in cyanobacteria biomass in late summer and early autumn (Wetzel, 2001; Beversdorf and others, 2013). This succession often happens in lakes but is frequently disturbed by influxes of turbid and nutrient-laden water that reduce light availability. In a study of the lake seasonal succession pattern in a Lancaster County, Nebraska, lake, cyanobacteria often became dominant within the phytoplankton community by about late June and sustained that dominance for most or all summer (Thomas, S.A., Singh, C., and Hoagland, K., University of NebraskaLincoln, written commun., 2013). Before this cyanobacteria dominance, the phytoplankton community was dominated by diatoms and smaller counts of other algae.

Cyanobacteria have several traits that allow them to outcompete other algal taxa under certain conditions that are often associated with late summer and early autumn in temperate, eutrophic lakes (Chorus and Bartram, 1999). When surface-water light availability is low (which happens during an influx of sediment-laden runoff or during a dense algal bloom), cyanobacteria can maintain higher growth rates than other phytoplankton. Cyanobacteria thrive in warmer water temperatures (greater than 77 degrees Fahrenheit $\left[{ }^{\circ} \mathrm{F}\right]$ ) compared with many other phytoplankton. Cyanobacteria possess several nutrient uptake adaptations that allow for a competitive advantage in relation to other phytoplankton (Chorus and Bartram, 1999).

Because of these traits, cyanobacteria can potentially flourish in aquatic systems that are warm, turbid, and eutrophic; that is, conditions that typify many lakes of the agricultural Midwest (Graham and others, 2004; Heisler and others, 2008). Cyanobacterial harmful algal blooms (CyanoHABs) can endanger animals and people that inhale or ingest toxins produced by some cyanobacteria. Management of CyanoHABs requires an understanding of nutrient dynamics within a waterbody. As a result, many mitigation strategies designed to reduce CyanoHABs rely on nutrient management to achieve this goal (Edmondson, 1970; Chorus and Bartram, 1999; Smith and Schindler, 2009; Paerl and Otten, 2013). Nutrient management of natural or closed-basin lakes may be a simple practice, such as chemically binding the bioavailable phosphorus in the lake (Cooke and others, 2005). However, many lakes receive nutrients from tributary streams, and nutrient management strategies for eutrophic lakes must happen throughout the lake drainage area to be effective. Basin-scale nutrient management can be difficult to achieve, and an understanding of nutrient transport is critical to reducing external nutrient loading.
Nutrient availability within a lake is highly dynamic and depends on many physical and biological processes (Dodds and Whiles, 2010). The phytoplankton community affects nutrient concentrations because they assimilate nitrogen and phosphorus. As phytoplankton die, the cells (along with the assimilated nutrients) settle to the lakebed. Lakebed sediments can become further enriched by the deposition of sedimentbound nutrients, especially phosphorus. The retention or release of these nutrients back to the water column from the sediment, also known as internal loading, is a complex function of the oxidative state of the lakebed sediments, the microbial community available to biotransform the sedimentbound nutrients, and the hydraulic characteristics of the lake (Boström and others, 1988; Powers and others, 2015). This internal loading of nutrients is another source of nutrients to the lake water column, but its contribution is often less than the external loading of nutrients in agricultural landscapes (Song and others, 2017).

Willow Creek Lake (fig. 1) was studied as part of a statewide assessment of lakes in Nebraska in the early 1990s (Spalding and others, 1992); the study determined nutrient enrichment and the resulting CyanoHABs were substantial problems. Large groundwater nutrient concentrations may have had an important role in lake nutrient enrichment and suggested further study to define groundwater and surfacewater interaction. Whiles and others (2000) computed stream macroinvertebrate biotic indices in the Willow Creek drainage basin and compared them to several potential explanatory factors, including water chemistry, using data collected during 1996 and 1997. Riparian land use had the strongest effect on stream-biotic impairment; they also suggested that lake water quality might be most affected by contributions from a small tributary on the southern side of the lake (hereafter referred to as the "South Tributary") and a separate tributary on the northern side of the lake (hereafter referred to as the "North Tributary") rather than by dominant flow contribution from the main stem of Willow Creek to the lake (Whiles and others, 2000).

The Nebraska Department of Environmental Quality began monitoring the beach at Willow Creek Lake for the microcystin toxin in 2006. Weekly samples during the recreation season of May through September are analyzed for total microcystin and compared to a Nebraska Department of Environmental Quality action level of 20 micrograms per liter $(\mu \mathrm{g} / \mathrm{L})$ (Brakhage, 2009). When the microcystin concentrations exceed that action level, the lake is put on alert status until two consecutive weekly samples produce toxin concentrations below the action level. During 2006 through 2014, Willow Creek Lake was put on "alert status" in 5 of those 9 years. Only full-body contact during recreational use of the lake (such as swimming) is prohibited when in alert status; however, overall recreational use decreases substantially when the lake is on alert status (Dan Sutherland, Nebraska Game and Parks Commission, oral commun., 2011).

To better understand factors affecting cyanobacteria concentrations in Willow Creek Lake, the U.S. Geological 
Survey (USGS), in cooperation with the Lower Elkhorn Natural Resources District, the Nebraska Department of Environmental Quality, the Nebraska Game and Parks Commission, the Nebraska Department of Natural Resources, the Nebraska Environmental Trust, and the University of Nebraska-Lincoln (UNL), completed a collaborative study of Willow Creek drainage basin and Willow Creek Lake (fig. 1) between 2012 and 2014. The objectives of this study were to quantify and characterize cyanobacteria densities in Willow Creek Lake, characterize potential causes of cyanobacteria blooms within the Willow Creek Basin, identify relations between cyanobacteria in Willow Creek Lake and potential causes, and provide information to use as guidance for managing cyanobacteria in Willow Creek.

\section{Purpose and Scope}

This report uses data collected from the Willow Creek drainage basin and Willow Creek Lake, with emphasis on intensive data collected between 2012 and 2014, to relate cyanobacteria and physicochemical water-quality properties, including external nutrient loading. The data supporting this report are provided in a separate data release (Hall and others, 2018).

\section{Description of Study Area}

Willow Creek Lake has a surface area of 700 acres and is in Pierce County in northeastern Nebraska (fig. 1). The lake was constructed in 1984 primarily for flood control to protect the community of Pierce and other towns along the North Fork Elkhorn River, of which Willow Creek is a tributary (fig. 1). The lake functions as a multiuse facility that supports irrigation supply, fishing, swimming, and boating. The surrounding recreation area provides opportunities for camping, hunting, hiking, biking, horseback riding, and snowmobiling.

\section{Hydrologic Characteristics}

Willow Creek Lake is fed primarily by Willow Creek from the west but also receives lesser inflow from tributaries entering the lake on the north and south shores (North Tributary and South Tributary, respectively; fig. 1A). Surface outflow from the lake is controlled by a dam spillway. At the top of the conservation pool, Willow Creek Lake has a surface area of 700 acres, a storage capacity of 6,585 acre-feet (acre$\mathrm{ft}$ ) (Nickel Engineering, 2012), and a mean depth of 9.4 feet (ft). The drainage area for the lake is 210 square miles $\left(\mathrm{mi}^{2}\right)$ (Spalding and others, 1992), and the ratio of drainage area to surface area is 192. Since the lake was constructed, long-term (1984-2014) mean streamflow at the Foster site about 4 miles (mi) upstream from the lake on Willow Creek (fig. 1) is about 21.5 cubic feet per second $\left(\mathrm{ft}^{3} / \mathrm{s}\right)$ (U.S. Geological Survey, 2015; Nebraska Department of Natural Resources, 2018), resulting in an average lake retention time of 0.42 years (or
154 days). Using the equation of Gill (1979) for medium-size sediments, the lake has a 95-percent trapping efficiency.

Soils in the basin are highly permeable, and streams in the basin have a strong hydrologic connection to groundwater. Stanton and others (2010) estimated that base flow contributes 64 percent of Willow Creek streamflow. The hydrologic connection of the lake with the underlying groundwater is limited in the eastern quarter because of the compacted clay liner (fig. 1B).

The High Plains aquifer system is the principal aquifer in Pierce County, Nebr. In the area around Willow Creek Lake, the surficial part of the High Plains aquifer is unconfined and the deeper part can be locally confined (Nickel Engineering, 2012). The eastern edge of the confining layer is near the lake dam, and the confining layer is discontinuous in the area around Willow Creek Lake, allowing interaction between the surficial and deeper parts of the aquifer. An analysis of data since 1986 from monitoring and pressure-relief wells on the dam revealed an upward pressure gradient resulting in seepage from the deeper part of the aquifer into the shallow part (Nickel Engineering, 2012). Groundwater flow in the area generally is from west to east (U.S. Geological Survey, 2015; Stanton and others, 2010). A series of 27 pressure-relief wells (not shown) screened as deep as $99 \mathrm{ft}$ below the land surface (Nickel Engineering, 2012) are along the downstream side of the dam to prevent groundwater levels and seepage from affecting the geotechnical properties of the dam structure. These wells discharge directly into Willow Creek downstream from the dam, and a measurement in 2011 by Nickel Engineering (2012) determined that they contributed $5.12 \mathrm{ft}^{3} / \mathrm{s}$ of flow to the creek.

\section{Contributing Area}

Subbasins within the Willow Creek Lake drainage basin are contiguous, but each have small differences in soil characteristics (Natural Resources Conservation Service, 2011). Area-weighted averages of the textural composition of the soil (sand, silt, and clay) and the erodibility were computed based on the relative areas of the various soil types in proportion to the entire area of a given subbasin. Erodibility was assessed using a quantitative index, the soil erodibility factor $(K f)$, with higher values representing greater erodibility (Schwab and others, 1993). The soils in the subbasin of the main branch of Willow Creek consist of an area-weighted average of 77 percent sand, 15 percent silt, and 8.7 percent clay, and have an average $K f$ of 0.152 . The soils of the subbasin of the North Tributary to the lake consist of an area-weighted average of 68 percent sand, 21 percent silt, and 11 percent clay, and have an average $K f$ of 0.171 , whereas the soils of the subbasin of the South Tributary to the lake consist of an area-weighted average of 77 percent sand, 14 percent silt, and 9.5 percent clay, and have an average $K f$ of 0.135 .

Primary land use within the Willow Creek drainage basin is agriculture. Land use within the basin was 62 percent cropland (primarily corn and soybean row crops) and 30 percent 


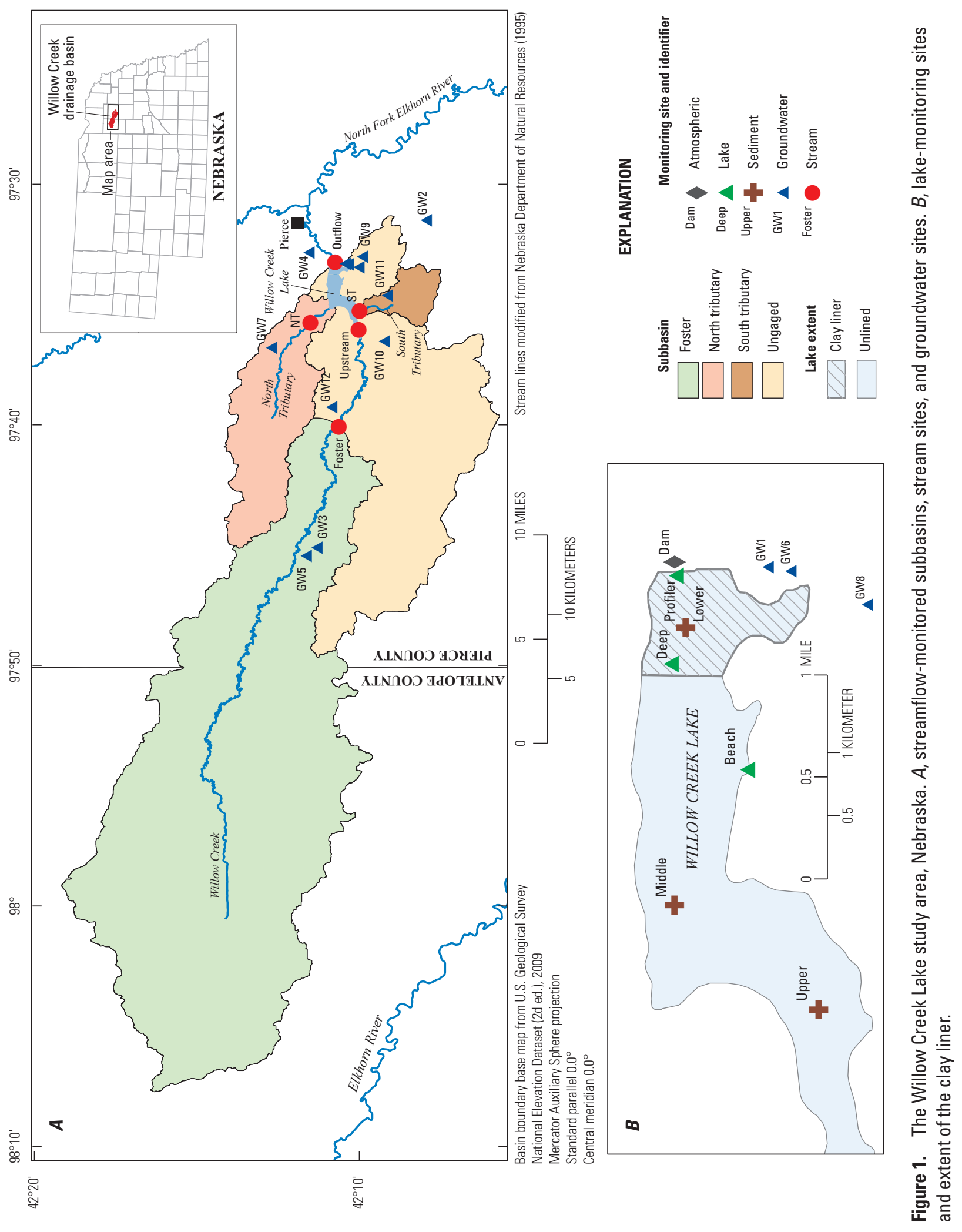


range and pastureland in 2011 (U.S. Department of Agriculture, 2014; Center for Advanced Land Management Information Technologies, 2017). The shallow groundwater table allows extensive irrigation of the cropland (Spalding and others, 1992). Land use is similar among the subbasins within the lake drainage basin; however, tile drains have been observed draining to the South Tributary, and tile drains have increased nitrate export from drainage basins in the cornbelt area of the Midwest (Fausey and others, 1995).

\section{Climate}

The Willow Creek drainage basin has a humid, continental climate; the most recent 30-year normals (1981-2010) for Norfolk, Nebr. (14 mi south-southeast from the lake), have a mean annual temperature of $49.3^{\circ} \mathrm{F}$ and mean annual precipitation of 27.3 inches (in.) (National Weather Service, variously dated). A wide range of climatic conditions were observed at Norfolk, Nebr., during the study (National Weather Service, variously dated). The first year of study, 2012, was characterized by a record high annual average temperature $\left(52.3^{\circ} \mathrm{F}\right)$ and was the second driest year on record (14.5 in. of precipitation), including record dryness for the summer season (June-August), July (no recorded precipitation), and the JuneNovember period. The 2013 conditions overall were nearly normal, with annual mean temperature only $0.8^{\circ} \mathrm{F}$ below normal and annual precipitation 2.48 in. below normal; however, the year featured a wet spring and dry summer. Although the final year of study began during a dry winter, 2014 was cooler (annual average of $48.3^{\circ} \mathrm{F}$ ) and wetter than normal, with annual precipitation 2.36 in. above normal because June and August were wet months. Wind speed increased slightly each year during the study, with average annual wind speeds of 10.2, 10.6, and $11.1 \mathrm{miles}$ per hour $(\mathrm{mi} / \mathrm{h})$ during the study years of 2012, 2013, and 2014, respectively. The wind speed during July-September averaged 8.7, 8.9, and $8.6 \mathrm{mi} / \mathrm{h}$ in 2012, 2013, and 2014, respectively.

\section{Methods}

The following sections describe the methods used to collect data that were used in this report and the statistical techniques used to correlate data types. Three different types of algal response data were collected and compared to potential explanatory data related to nutrient loading into Willow Creek Lake (fig. 1).

Although historical data from as early as 1989 were compiled, the study focused on the recent monitoring period of 2012-14. More specifically, the focus was on intensive data collected from March 1, 2012, through October 1, 2014. Much of that data collection was seasonal from spring through autumn and did not include winter conditions, although some data-gap filling was done to better represent the entire period.

\section{Monitoring Sites}

Monitoring data were collected or compiled from several sites in or near the Willow Creek drainage basin (figs. $1 A$ and $1 B$; table 1). Data from the lake came from six sites, including three lake sediment coring sites (lower, middle, and upper), a sampling site at the beach (beach), a sampling site in the middle of the lake (deep), and a continuous-monitoring site near the dam (profiler; fig. 1B).

Stream chemistry data were collected from five sites, four of which also included continuous streamflow: Willow Creek near Foster (Foster) about 4 mi upstream from the lake, Willow Creek near Pierce (outflow) about 2 mi downstream from the lake, North Tributary to Willow Creek Lake (NT) about $0.5 \mathrm{mi}$ upstream from the lake, and South Tributary to Willow Creek Lake (ST) about $300 \mathrm{ft}$ upstream from the lake; the remaining site is Willow Creek upstream from Willow Creek Lake (upstream) (fig. 1A). The area drained by the three inflow monitoring sites (Foster, NT, and ST) is about 75 percent of the Willow Creek drainage basin, and the remaining 25 percent is the ungaged area (primarily immediately around the lake or between the Foster site and the lake). The largest subbasin is gaged at the Foster site and drains 64 percent of the basin $\left(133 \mathrm{mi}^{2}\right)$. The NT site represents 8.7 percent of the basin $\left(18 \mathrm{mi}^{2}\right)$, and the small ST subbasin area is only 1.7 percent of the basin $\left(3.5 \mathrm{mi}^{2}\right)$.

Groundwater data were collected or compiled at 12 groundwater sites near the lake (table 1; fig. $1 A$ ). Meteorological data were collected using equipment deployed at an atmospheric site at the dam (dam, fig. 1B). Other meteorological data were obtained from the National Climatic Data Center (2015), including precipitation data from Pierce, Nebr., and temperature, wind speed, and wind direction data from Norfolk, Nebr.

\section{Cyanobacteria in Willow Creek Lake}

Three quantitative measures of the cyanobacteria population in Willow Creek Lake characterized the algal response in the lake. Algal samples were discretely collected from the beach site (fig. $1 B$; table 1 ) to determine concentrations of the cyanotoxin microcystin and algal abundance and community composition. The algal pigments chlorophyll $a$ and phycocyanin were continuously measured. Chlorophyll $a$ is a light-gathering pigment contained in all photosynthetic organisms, and phycocyanin is an accessory pigment unique to cyanobacteria and some red algae (Rhodophyta) (Hambrook Berkman and Canova, 2007).

\section{Microcystin Sampling}

As a part of the statewide Public Beach Monitoring Program-Bacteria and Microcystin, the Lower Elkhorn Natural Resources District collected weekly samples at Willow Creek Lake to monitor microcystin concentrations (Nebraska 
Table 1. Monitoring sites and corresponding data.

[ID, identifier; CWQ, continuous water quality; WL, water level; USGS, U.S. Geological Survey; NDNR, Nebraska Department of Natural Resources; --, none assigned; MC, discrete microcystin sampling; A, discrete algal community sampling; LENRD, Lower Elkhorn Natural Resources District; C, discrete water chemistry sampling; NDEQ, Nebraska Department of Environmental Quality; sed., sediment; S, discrete sediment chemistry sampling; UNL, University of Nebraska-Lincoln; Atm., Atmospheric; M, meteorological data; NCDC, National Climatic Data Center; Q, streamflow; GW, groundwater.]

\begin{tabular}{|c|c|c|c|c|c|c|c|}
\hline $\begin{array}{l}\text { Site ID } \\
\text { (fig. 1) }\end{array}$ & Site type & Site name & Source $^{1}$ & Station ID & $\begin{array}{l}\text { Data } \\
\text { collected }\end{array}$ & $\begin{array}{c}\text { Period of } \\
\text { data collection }\end{array}$ & $\begin{array}{l}\text { Agency } \\
\text { collecting data }\end{array}$ \\
\hline Profiler & Lake & Willow Creek Lake & 1 & 06799089 & $\begin{array}{l}\mathrm{CWQ}, \\
\mathrm{WL}^{2}\end{array}$ & $4 / 2012-10 / 2014$ & USGS, NDNR \\
\hline Beach & Lake & Willow Creek Lake beach & 2 & -- & $\mathrm{MC}^{2}, \mathrm{~A}$ & $5 / 2006-10 / 2014$ & LENRD, USGS \\
\hline Deep & Lake & Willow Creek Lake chemistry & 2 & -- & $\mathrm{C}^{2}$ & 7/1989-9/2014 & NDEQ \\
\hline Lower & Lake sed. & Cores-Deep & 1 & -- & $\mathrm{S}$ & 5/2013-10/2014 & UNL \\
\hline Dam & Atm. & Local Meteorology & 1 & -- & M & $8 / 2012-10 / 2014$ & USGS, NCDC \\
\hline Foster & Stream & Willow Creek near Foster & 1,3 & 06799080 & $\mathrm{WL}, \mathrm{Q}^{2}, \mathrm{C}$ & 10/1975-present & NDNR, LENRD \\
\hline ST & Stream & $\begin{array}{l}\text { South Tributary to Willow } \\
\text { Creek Lake }\end{array}$ & 1 & 420959097351702 & WL, Q, C & $9 / 2012-8 / 2014$ & LENRD, USGS \\
\hline Upstream & Stream & $\begin{array}{l}\text { Willow Creek upstream from } \\
\text { Willow Creek Lake }\end{array}$ & 1 & 421650709761031 & $\mathrm{C}$ & $10 / 2012-8 / 2014$ & LENRD \\
\hline Outflow & Stream & Willow Creek near Pierce & 3 & -- & $\mathrm{WL}, \mathrm{Q}^{2}$ & $1 / 1984-10 / 2014$ & NDNR \\
\hline GW1 & GW & GW-18S & 1 & -- & $\mathrm{C}$ & $8 / 20 / 2013$ & LENRD, USGS \\
\hline GW2 & GW & GW Nutrients 1 & 4 & 420756097312901 & $\mathrm{C}$ & $6 / 25 / 1964$ & USGS \\
\hline GW3 & GW & GW Nutrients 2 & 4 & 421118097450501 & $\mathrm{C}$ & $7 / 24 / 1968$ & USGS \\
\hline GW4 & GW & GW Nutrients 3 & 4 & 421133097324901 & $\mathrm{C}$ & $11 / 9 / 1968$ & USGS \\
\hline GW5 & GW & GW Nutrients 4 & 4 & 421138097452601 & $\mathrm{C}$ & $7 / 24 / 1968$ & USGS \\
\hline GW6 & GW & GW Nutrients 5 & 5 & 128264 & $\mathrm{C}$ & $8 / 20 / 2013$ & LENRD \\
\hline GW12 & GW & GW Nutrients 11 & 5 & 75578 & $\mathrm{C}$ & $7 / 5 / 2006$ & LENRD \\
\hline
\end{tabular}

${ }^{1}$ Sources of data: 1, Collected as part of this study; 2, Nebraska Department of Environmental Quality (2015); 3, Nebraska Department of Natural Resources (written commun., 2013, 2014, and 2015); 4, U.S. Geological Survey (2015); 5, Exner and others (2005).

${ }^{2}$ As of 2018 , data continue to be collected at this site. 
Department of Environmental Quality, 2015). The monitoring generally followed the procedures described by Graham and others (2008) for recreational areas. Sampling happened weekly during May through September 2006 to 2014. Grab samples were collected from the water surface by wading at the beach site on the south shore (fig. 1B). At the Nebraska Department of Environmental Quality laboratory in Lincoln, Nebr., the samples underwent three freeze-thaw cycles to lyse the cells before analysis using the enzyme-linked immunosorbent assay technique to measure total microcystin concentration (Metcalf and Codd, 2003).

\section{Algal Abundance and Community Composition Sampling}

Phytoplankton community samples were collected at the beach site (fig. $1 B$ ) for taxonomic enumeration and identification (Graham and others, 2008). Two samples were collected in late summer 2013; during 2014, eight samples were collected regularly at about 3-week intervals from April to September. One-quart grab samples were collected from just beneath the water surface near the beach site. Samples were preserved in the field with Lugol's iodine solution and kept cold until analyzed. Algal taxonomic identification (to genus level), enumeration, and biovolume were determined microscopically by Phycotech, Inc. (St. Joseph, Michigan), following standard procedures (Olrik and others, 1998; Hillebrand and others, 1999; Rice and others, 2012). The biovolume metric was selected over abundance to account for size variability among algal genera.

\section{Continuous Algal Monitoring}

A raft-mounted continuous water-quality monitor was deployed in the lake at the profiler site (fig. 1B). The system was equipped to measure algal data and water-quality physical properties on a continuous basis at multiple depths. It consisted of a winch that raised and lowered the water-quality monitor, a controller, a data collection platform, a cellular modem that allowed remote programing and data retrieval, and connecting cables. The system was deployed near the deepest part of the lake (about $19.7 \mathrm{ft}$ [6 meters] deep at the top of the conservation pool) and set to measure water column vertical profiles hourly.

During the first 2 years of the study, profiles consisted of readings at depths (from the water surface) of 1.6, 3.3, $4.9,6.6,9.8,13.1$, and $16.4 \mathrm{ft}$, with lake depths sometimes preventing readings at the lower three depth intervals. Vertical stratification was explored using the relative standard deviation (RSD), or the standard deviation of the measurements at all the depths for a given time divided by the mean of those measurements, giving a unitless metric of variation (Mueller and others, 2015). Small RSD values indicated measurements across all the depths differed little, suggesting well-mixed conditions. Conversely, large RSD values suggested the possibility of stratification across the depths. Monitoring data from the first 2 years indicated little stratification in Willow Creek Lake and included periodic data gaps related to equipment malfunctions. Therefore, during the final year of the study, the multiparameter sonde was deployed at a fixed depth of $1.6 \mathrm{ft}$ while another sensor capable of measuring water temperature and dissolved oxygen was deployed $1.6 \mathrm{ft}$ above the lakebed, at a typical depth of about $13 \mathrm{ft}$.

The multiparameter sonde (6-series equipment manufactured by YSI Incorporated, 2011) measured seven parameters for each reading, including five physical properties, water temperature, specific conductance, $\mathrm{pH}$, dissolved oxygen, and turbidity; and two biological parameters, the photosynthetic pigments chlorophyll $a$ and phycocyanin. Sensors for the five physical properties were operated and maintained in accordance with quality-assurance procedures in Wagner and others (2006), whereas operation and maintenance of the other sensors followed manufacturer recommendations and relied on the use of Rhodamine water temperature dye solutions as a calibration standard (YSI Incorporated, 2011). The biological parameters were measured based on light excitation and emission characteristics of photosynthetic pigments at particular wavelengths (YSI Incorporated, 2011) and were used as relative measures of the phytoplankton population within the lake. Chlorophyll $a$ often is used as an indicator of algal biomass in aquatic ecosystems. Though chlorophyll $a$ data were collected for the study, they are not included in this report out of concern for data quality issues observed during the course of the study, specifically when compared to laboratory-derived analyses of chlorophyll $a$ and a lack of seasonality in the optically derived measurements.

The phycocyanin readings measured the amount of the photosynthetic pigment, phycocyanin, which is present within cyanobacteria as well as some red algae species (Dodds and Whiles, 2010), as the amount of light emitted at 650 nanometers $(\mathrm{nm})$ when excited with light at $590 \mathrm{~nm}$. The phycocyanin excitation was automatically converted to a cell-density metric of cyanobacteria cells per milliliter using a vendor-specific algorithm (YSI Incorporated, 2011). Although the phycocyanin data are compiled using the vendor derived units of cells per milliliter, for this study the data are considered to be a relative measure of cyanobacteria abundance that was useful for detecting changes in the lake rather than as an absolute metric of cyanobacteria cell density.

The sonde collected hourly measurements, but these data were summarized into daily means for comparison to other data. Several steps were done to ensure a complete record of phycocyanin daily values during each monitoring season (March 1-November 1). Overall, 28 percent of the daily values were missing during the 3-year study. Of those gaps, 68 percent were from the months of March and April before the sonde was deployed for the season but also when cyanobacteria values are expected to be low. Gaps in March and April were filled by establishing a sinusoidal relation of the phycocyanin measurements throughout the monitoring season to the Julian day (Spearman's correlation coefficient of 
determination $\left[R^{2}\right]$ of the relation was 0.66$)$, and then applying that relation to predict phycocyanin values during the gaps of March and April. This is a simplified approach that overlooks most of the complexity of the cyanobacteria community; however, it was considered adequate given the much lower values of phycocyanin during the early spring. The remaining gaps between May and November were filled by interpolating between the measured values that bracketed those gaps.

\section{Characterization of Physicochemical Water- Quality Properties Within the Willow Creek Basin}

Several physicochemical characteristics were measured in the Willow Creek Basin to relate to cyanobacteria response data. This study focused on four primary types of environmental data: external nutrient loading into the lake through streamflow and groundwater, which also used local atmospheric and meteorological data; internal nutrient loading through cycling within the lake; and continuous monitoring of physical properties of the lake water.

\section{External Nutrient Loading}

A variety of nutrient sources transported by multiple flow paths contribute to the nutrient load entering Willow Creek Lake. In addition to Willow Creek, several smaller tributaries contribute streamflow to the lake (fig. 1A). As Spalding and others (1992) noted, groundwater interactions with the lake are likely another important contributor to nutrient loading. Nutrient load was computed as the product of volumetric flow rate and nutrient concentration and was applied to streamflow and groundwater. A water balance approach was used to estimate the volumetric flow rates (hereinafter referred to as "flow") for streams and atmospheric sources, with groundwater flow as the residual of that balance. Nutrient concentrations were determined from sampling data.

\section{Surface-Water Flows}

Streamflow was measured at the three largest inflows (Foster, NT, and ST sites) and the outflow of the lake (outflow site; fig. $1 A$; table 1 ). Flow data were typically available at a 15-minute frequency but generally were summarized as daily means. Flow data for the Foster, NT, and outflow sites were provided by the Nebraska Department of Natural Resources (Hall and others, 2018; table 1) and were estimated using stage-flow relations applied to measured stage following protocols described by Kennedy (1983). The Foster and outflow sites are long-term streamgages that had continuous data available throughout the study period. At the NT site, established specifically for this study, equipment malfunctions introduced gaps in the flow record for 225 of the 944 days of the monitoring period. Those gaps were filled in one of two ways: (1) when available, secondary water-level data from an auxiliary pressure transducer operated by the USGS were correlated to flow measurements to obtain an auxiliary stageflow relation for the site that was used to estimate flow during gaps in the primary record; or (2) when no water-level data were available for the NT site (which generally happened in the spring of 2012), flow was estimated as a fraction of that measured at the Foster site based on the ratio of their corresponding drainage areas $(0.136)$. When results for both gapfilling methods were compared to the flow data provided by the Nebraska Department of Natural Resources, the auxiliary stage-flow relation was preferred. However, primary and secondary water-level data were unavailable before May 2, 2012, and several large flow events (as indicated by rainfall data and Foster site flow data) were estimated at the NT site using the drainage-area ratio.

Flow at the ST site was measured by the USGS using an indirect rating curve with water levels monitored continuously by a submersible pressure transducer and periodic streamflow measurements collected using a Parshall flume (Kilpatrick and Schneider, 1983). Continuous flow measurement at this site began in September 2012 to better represent the nutrient loading contribution from the ST site. Data gaps were on 444 of 944 days of the flow record primarily because of ice effects and equipment malfunction. Those gaps were filled in one of two ways. Flow at the site ceased on about August 7, 2012, based on evidence from monthly visits to the site as well as the flow record at the Foster site. Flow did not resume at the ST site until March 8, 2013, based on data from the pressure transducer. As a result, flow during that intervening period was assigned uniform values of zero. ST flows between March 1 and August 6, 2012 (no water-level data), and again between December 23, 2013, and March 30, 2014 (water levels affected by ice), were estimated as a fraction of the flow recorded at Foster site based on the ratio of their corresponding drainage areas (0.026).

Drought conditions during 2012 and early 2013 had a large effect on surface-water flows to and from the lake. Within 4 months of the start of the study, surface outflow ceased as the water level in the lake dropped below the spillway elevation, and outflow did not resume during the remainder of the study. However, flow was observed in Willow Creek at the outflow measurement site, located downstream from the dam, for most of the study because of contributions from pressure-relief wells along the dam (Nickel Engineering, 2012). In response, the measured flows at the outflow site were adjusted downwards to better represent the surface outflow. Outflows were reduced by $4.0 \mathrm{ft}^{3} / \mathrm{s}$ before the spillway going dry on June 14, 2012 and were set to zero thereafter. In addition, Willow Creek was observed as dry where its channel entered the lake on July 26 and September 18, 2012, despite the continuous presence of flow $3.7 \mathrm{mi}$ (6 kilometers) upstream at the Foster site. Based on the Foster flow values on those two dates, an approximation of $3.0 \mathrm{ft}^{3} / \mathrm{s}$ of streamflow was lost as seepage to groundwater between the Foster site and the lake; consequently, Foster flow values were adjusted down by that amount (or until a flow of $0 \mathrm{ft}^{3} / \mathrm{s}$ was reached) for the entire 
study period. This approach is an oversimplification of the interaction of surface water and groundwater in that reach and introduces some uncertainty into the loading estimates for the stream, but a more complex approach was outside of the scope of this study. Furthermore, all the streamflow estimates were affected by imprecision in measurements, oversimplification from assumptions, and variability related to gap-filling. That uncertainty was minimized using standard approaches to the extent possible, but the streamflows and corresponding loads have an inherent uncertainty associated with them.

\section{Lake Storage}

The volume of water stored in the lake at any given time was provided by the Nebraska Department of Natural Resources (written commun., 2013, 2014, 2015; Hall and others, 2018). The volumetric values were derived from daily measurements of lake water level in conjunction with a table relating the storage volume to those water levels that was developed at the time of lake construction (Lower Elkhorn Natural Resources District, written commun., 2012). Lake sedimentation may have affected this water level-storage relation by occupying part of the lowest pool of the lake volume (that is, below the spillway elevation, also known as dead storage), leading to overestimation of the actual water storage volume. However, the main use of the storage data was in estimating the change in storage during periods of 1 year or less and decreases in dead storage are presumed to have had negligible effect on those estimates.

\section{Evaporation, Precipitation, Net Radiation, Heat Storage, and Meteorological Data}

As components of the water balance, evaporation and precipitation were measured throughout the study period and were assigned nutrient concentrations of zero based on the negligible concentrations of $\mathrm{N}$ and $\mathrm{P}$ in samples of wet deposition reported from regional studies (Anderson and Downing, 2006; National Atmospheric Deposition Program, 2016). Meteorological data were either collected at the lake or compiled from the National Climatic Data Center (2015). An atmospheric station was deployed on the dam (dam site; fig. $1 B$ ) to measure hourly air temperature, relative humidity, wind speed and direction, solar radiation, and photosynthetically active radiation between August 3, 2012 (or April 30, 2013, for some parameters), and October 30, 2014. The surface area of the lake was estimated on a daily basis (Hall and others, 2018) using daily storage volume and a table relating storage volume to surface area that was developed at the time of lake construction (Lower Elkhorn Natural Resources District, written commun., 2012) These data were used to calculate evapotranspiration using the Priestly-Taylor equation for potential evapotranspiration for shallow lakes (Rosenberg and others, 1983). Net radiation was calculated following Allen and others (1998) using measured solar radiation, when available, or calculated solar radiation otherwise. Heat storage within the lake was calculated using the daily lake volume and the measured water temperature. Other meteorological data were obtained from the National Climatic Data Center (2015), including precipitation data from Pierce, Nebr., and data from Norfolk, Nebr., which were used to fill gaps in measured meteorological datasets. Meteorological data such as wind speed and direction, solar radiation, and photosynthetically active radiation were possible explanatory variables for elevated cyanobacteria concentrations.

\section{Water Balance}

Flow interaction between the lake and groundwater was calculated from a lake water balance (Healy and others, 2007) in which that interaction was the residual, and the remaining components were measured or estimated as already described. Inflow terms consisted of the streamflow at the Foster, NT, and ST sites (fig. $1 A$ ) as well as the direct precipitation onto Willow Creek Lake. Measured outflow terms consisted of the streamflow at the outflow site and the direct evaporation from the lake. Increases in lake storage had the same effect on the water balance as an outflow. The resulting equation used for the water balance was

$$
G W=\text { Foster }+N T+S T+P-\text { Outflow }-E-\Delta S
$$

where

$\begin{aligned} G W & \text { is groundwater flow interaction with the lake; } \\ \text { Foster } & \text { is inflow to the lake from the Foster site; } \\ N T & \text { is inflow to the lake from the NT site; } \\ S T & \text { is inflow to the lake from the ST site; } \\ P & \text { is precipitation falling directly on the lake; } \\ & \text { and }\end{aligned}$

Outflow is flow measured at the outflow site;

$E \quad$ is evaporation from the lake; and

$\Delta S \quad$ is the change in lake storage volume.

All components of the water balance were tabulated daily and converted to units of acre-feet per day. As written, this water balance considers GW interaction as an outflow, but this interaction can be an inflow or an outflow. Positive values of groundwater represent flow from the lake into the groundwater, and negative values represents a gain of water to the lake from groundwater. One limitation of this analysis technique is that it is unable to determine the extent that groundwater flows through the lake without changing the net water balance. This would be possible any time the local groundwater level intersects the lakebed and would have the potential to affect the nutrient loading to the lake depending upon the relation between the groundwater and lake nutrient concentrations.

\section{Water Chemistry Sampling}

Chemistry data were collected or compiled from stream water, lake water, and groundwater. Stream water samples were collected more frequently to capture the range of streamflow conditions. Discretely collected samples were analyzed for nitrogen content (total Kjeldahl nitrogen [TKN], nitrate plus nitrite as nitrogen $\left[\mathrm{NO}_{3}\right]$, and ammonium as nitrogen 
$\left[\mathrm{NH}_{4}\right]$ ) and phosphorus content (total phosphorus [TP] and phosphate as phosphorus $\left[\mathrm{PO}_{4}\right]$; table 2). A subset of samples were analyzed for nitrogen and oxygen isotopes associated with nitrate and phosphate, respectively, to identify nutrient sources in Willow Creek Lake.

Stream water samples were collected using two protocols throughout the study. Surface-water sites (table 1) were sampled about monthly during the summer and once during the winter by manually collecting a grab sample from the middle of the stream cross section during base flow conditions. Automatic samplers (Teledyne Isco, model Avalanche) deployed at the Foster and NT sites were used to collect samples during runoff conditions. A water-level sensor was deployed in the channel to begin a preprogrammed sampling routine once water levels increased to a certain threshold. Typically, 14 individual sample bottles were filled during a given sampling event and were separated by preprogrammed intervals according to the hydrologic response of each site. The sampling intake at both sites was positioned near the bank just below the low-water level. Although the upstream site was not used for load analysis or streamgaging, samples were collected at this site just upstream from the lake on Willow Creek (fig. 1) to determine if water chemistry changed between the Foster site and the lake. A subset of quality-control samples was collected to assess variability (using replicate samples) and the presence of contamination (using blank samples). The analytical results from these quality-control samples are provided in Hall and others (2018) and did not suggest systematic contamination or unexpected variability. Surface water samples were not collected from the outflow because of drought conditions during the study period.

Groundwater was sampled following USGS protocols (U.S. Geological Survey, variously dated) at 4 selected wells near Willow Creek Lake (Hall and others, 2018). However, further review of the lithologic information for each of those wells suggested that only one (GW1, fig. 1; also listed as GW18S in Hall and others, 2018) was shallow enough to represent groundwater that might be in connection with the lake. As a result, groundwater-quality data for an additional 11 wells (fig. 1; table 1) sampled before the study were compiled from the USGS National Water Information System (U.S. Geological Survey, 2015) and the Quality-Assessed Agrichemical Contaminant Database for Nebraska Ground Water (Exner and others, 2005).

Lake samples were collected about monthly during May through September by the Nebraska Department of Environmental Quality (2016) as a part of the Ambient Lake Monitoring Program. Lake samples were analyzed for several constituents, including nutrients and chlorophyll $a$ (Hall and others, 2018). These data were analyzed to evaluate nutrient availability, use, cycling, and possible biological limitations within the lake. Focus was given to nitrogen and phosphorus concentrations, the ratio of nitrogen to phosphorus, and whether nitrogen or phosphorus might be limiting algal growth.

Table 2. Analytes, methods, and laboratories for inflow and groundwater samples collected for Willow Creek Lake, 2012-14.

[EPA, U.S. Environmental Protection Agency (2013); UNL, University of Nebraska-Lincoln; --, undefined; SM, Standard Methods for the Examination of Water and Wastewater (Rice and others, 2012)]

\begin{tabular}{llc}
\hline \multicolumn{1}{c}{ Analyte } & \multicolumn{1}{c}{ Lab } & \multicolumn{1}{c}{ Reference } \\
\hline Nitrate plus nitrite as nitrogen $\left(\mathrm{NO}_{3}\right)$ & Midwest Laboratories, Inc. & EPA 353.2. \\
Total Kjeldahl nitrogen $(\mathrm{TKN})$ & UNL Water Sciences Laboratory & EPA 353.2. \\
Ammonium nitrogen $\left(\mathrm{NH}_{4}\right)$ & Midwest Laboratories, Inc. & -- \\
Dissolved phosphorus & UNL Water Sciences Laboratory & SM 4500-NH3C. \\
Total phosphorus $(\mathrm{TP})$ & UNL Aquatic Ecology Laboratory & -- \\
Phosphate as phosphorus $\left(\mathrm{PO}_{4}\right)$ & Midwest Laboratories, Inc. & SM 4500-P H. \\
& Midwest Laboratories, Inc. & SM 4500-P G. \\
& UNL Water Sciences Laboratory & SM 4500-P F. \\
\hline & UNL Aquatic Ecology Laboratory & -- \\
\hline Oxygen-18 $\left({ }^{18} \mathrm{O}\right)$ in phosphate & Isotopes & McLaughlin and others (2004). \\
${ }^{18}$ O in nitrate & UNL Water Sciences Laboratory & Chang and others (1999). \\
Nitrogen-15 $\left({ }^{15} \mathrm{~N}\right)$ in nitrate and ammonia & UNL Water Sciences Laboratory & Gormly and Spalding (1979). \\
\hline
\end{tabular}




\section{Analytical Chemistry Techniques}

Stream and groundwater samples were analyzed for nutrient and isotope concentrations. Sample analytes, analysis methods, and laboratories are listed in table 2. Three laboratories were used for analysis of samples collected for this project. Stream and groundwater samples were analyzed for TKN, $\mathrm{NO}_{3}, \mathrm{TP}$, and $\mathrm{PO}_{4}$ by Midwest Laboratories Inc., Omaha, Nebr. A subset of samples were analyzed for $\mathrm{NO}_{3}$ and $\mathrm{PO}_{4}$ concentrations at the UNL Water Science Laboratory in support of sampling for the isotope oxygen-18 $\left({ }^{18} \mathrm{O}\right)$ in phosphate and nitrate and for the isotope nitrogen-15 $\left({ }^{15} \mathrm{~N}\right)$ in nitrate and ammonium. Those isotope results are included in Hall and others (2018) but are not synthesized in this report. Water-column samples associated with sediment-core incubations (described in the "Internal Nutrient Loading" section) were analyzed for $\mathrm{PO}_{4}$ and dissolved phosphorus by the UNL Aquatic Ecology Laboratory (Hall and others, 2018).

\section{Load Computations}

Nutrient loading into and out of the lake was quantified using multiple techniques, all of which linked volumetric water flux along a flow path with nutrient concentrations. Surfacewater inflows were estimated using the program LOADEST (Runkel and others, 2004). Using the streamflow record and sampling results, LOADEST builds a regression for nutrient loads based on variables such as flow and time of year. Streamflow and nutrient concentrations were both logarithmtransformed to ensure the statistical assumptions of the regression were met, including residual normality (Helsel and Hirsch, 2002). Regression equations were evaluated based on statistical goodness of fit and avoided the use of quadratic relations to streamflow to prevent excessive extrapolation errors in the load estimates. The LOADEST model is described in appendix 1.

Groundwater loading was estimated by assigning a static nutrient concentration to the groundwater flow component estimated from the water balance. Groundwater transport was assumed to be limited to the soluble forms of nitrogen $\left(\mathrm{NO}_{3}\right)$ and phosphorus $\left(\mathrm{PO}_{4}\right)$. Nutrient concentrations assigned to positive groundwater flow (into the lake) were taken as the unweighted mean of samples from wells in the shallow aquifer (table 1). Nutrient concentrations assigned to the negative groundwater flow (out of the lake) were estimated from concentrations measured in the lake. For phosphate, the concentration was assumed to be zero out of simplicity because few lake samples were above the detection limit for phosphate. $\mathrm{NO}_{3}$, however, was more complex, with a clear seasonal trend in the lake showing highest concentrations in early spring and lowest concentrations in late summer that was represented using a seasonal estimate of lake $\mathrm{NO}_{3}$ derived from sample data.

Loads were summarized in several ways. Calculated total loads were normalized to the lake area to provide surface loading rates. Total nitrogen was estimated as the sum of TKN and $\mathrm{NO}_{3}$. Daily nutrient loads were totaled across multiple time scales.

\section{Internal Nutrient Loading}

Sediment cores were collected from Willow Creek Lake on two occasions between 2013 and 2014 and incubated to quantify phosphorus exchange with the water column under anoxic conditions using techniques similar to those of Penn and others (2000). Two-inch diameter cores were collected in triplicate from a boat using direct-push coring techniques. Sediment recovery varied between 4 and 14 in. in length, and cores were chilled before the incubation process at the laboratory. Cores came from three locations longitudinally distributed within the lake: close to the dam (lower site), in the middle of the lake (middle site), and in the upper arm toward the inflow of Willow Creek (upper site; fig. $1 B$ ). Additional cores were collected from the middle site for use as controls that were incubated under oxic conditions. Willow Creek water was collected from the middle site for use in all incubations. All cores were returned to the laboratory and sealed in a column with a rubber stopper outfitted with inflow and outflow ports. Cores were incubated in a water bath held at $73^{\circ} \mathrm{F}$. A flow-through system circulated filtered Willow Creek Lake water (pore size of 11 microns) through the water column above the sediment surface (about 0.03 ounce per minute). Incoming flow entered the water column about $0.8 \mathrm{in}$. above the sediment surface and was withdrawn about 0.4 in. above the sediment surface. Water column depth between the bottom of the stopper and the top of the sediments was recorded. Individual flow rates were measured periodically during the incubation period (7 days) for each core.

For the first 12 hours, each core was exposed to aerated water to allow sediments to settle before assessing nutrient release under anaerobic conditions. Phosphorus release experiments began when anoxia was established by bubbling nitrogen gas through one of the tanks containing filtered lake water. The nitrogen bubbling reduced and maintained dissolved oxygen levels to concentrations less than 1 milligram per liter (mg/L). Concurrently, a well-oxygenated vessel of filtered lake water was maintained to measure sediment cores under oxic conditions as controls. For each set of sediment cores collected, three control cores were treated with oxic water. Phosphorus samples ( $\mathrm{PO}_{4}$ and dissolved phosphorus) were collected periodically from the water exiting the column for 6 days after the onset of anaerobic conditions. These samples were analyzed in the Aquatic Ecology Laboratory in the School of Natural Resources at the UNL (table 2).

All nutrient samples were preserved and analyzed as described above. $\mathrm{PO}_{4}$ release rates (milligrams of phosphorus per square meter per day $\left[\mathrm{mg} \mathrm{P} / \mathrm{m}^{2} / \mathrm{d}\right]$ ) were estimated by dividing the change in $\mathrm{PO}_{4}$ concentration by the water residence time in the core chamber (core water volume divided by the pump flow rate) and correcting for the sediment area in each core. Cumulative $\mathrm{PO}_{4}$ fluxes were estimated by summing the release rates through time during the experimental incubation. Variability in the release rates caused by heterogeneity of the lake sediments was lessened by the collection of triplicate samples, and average release rates were computed accordingly. 


\section{Continuous Monitoring of Nonalgal Lake Factors}

In addition to the chlorophyll $a$ and phycocyanin data collected by the raft-mounted hydrologic monitoring system described earlier (in the "Continuous Algal Monitoring" section), water temperature, specific conductance, $\mathrm{pH}$, dissolved oxygen, and turbidity also were measured by this system and were used as possible explanatory variables for cyanobacteria. Deployment of the raft-mounted system began in April and continued through October of each year, with variables measured on an hourly basis during the deployment. For the first 2 years of the study, vertical profiles were measured hourly; however, equipment malfunctions associated with the profiling process led to periodic gaps in the data. In response, during the third year of the study all variables were measured at a depth of $1.6 \mathrm{ft}$, and a second set of measurements of water temperature and dissolved oxygen were made $1.6 \mathrm{ft}$ above the lakebed. Potential stratification of the lake was examined by comparing corresponding values between those two depths. Although gap-filling techniques were used to compile a complete daily record of phycocyanin data between March 1 and October 1 of each year, similar techniques were not applied for any of the physical properties.

\section{Relating Cyanobacteria Concentrations and Physicochemistry}

The relation between cyanobacteria and physicochemical factors was explored with bivariate (one response variable and one explanatory variable) and multivariate (one response variable and multiple explanatory variables) comparisons. Bivariate comparisons explored relations between cyanobacteria and one factor, and a multivariate statistical approach was used to explore the effect of multiple variables on cyanobacteria. For hypothesis testing, the significance level (probability coefficient [ $p$-value]) was compared to a threshold value of 0.05 to determine the probability of rejecting a correct hypothesis.

Data were collected at multiple frequencies, with hourly measurements of some factors and only weekly measurements of others; therefore, data were summarized in consistent temporal divisions. Daily, biweekly, monthly, and annual summaries were compared. Biweekly summary statistics preserved the general trends of the high-frequency data while reducing the effect of variability inherent in all datasets. Except for nutrient loading data, these summaries were computed as the mean of all measurements within the 2-week period. Biweekly nutrient loads were computed as the sum of the daily nutrient loads within the 2 -week period. In addition, the cumulative nutrient loads also were computed as the running total of nutrient loads in each year.

Bivariate comparisons were made to quantify relations between cyanobacteria and measured water-quality constituents using an ordinary-least squares regression approach (Helsel and Hirsch, 2002). These relations were then used to refine development of a first-order multivariate equation for cyanobacteria using a general linear model for the regression (Ott and Longnecker, 2001). The complexity of the model was intentionally kept simple to avoid introduction of factors that may improve the prediction of cyanobacteria but are physically unrealistic or unexplainable and to avoid multicollinearity. However, some data varied over several orders of magnitude, and logarithmic data transformations were applied to those data to meet the data distribution assumptions used by the regression. Model performance was evaluated first by confirming that residuals were normally distributed and then minimizing the residual standard error. The Nash-Sutcliffe efficiency (NSE; Nash and Sutcliffe, 1970) was used for model validation by comparing model performance using the population mean as a predictor. A perfect model prediction has an NSE of one, a model that performs as well as the mean value has an NSE of zero, and negative NSE values suggest that the sample mean is a better predictor than the model.

\section{Cyanobacterial Characteristics in Willow Creek Lake}

All cyanobacterial datasets in Willow Creek Lakemicrocystin concentrations, algal communities, and continuous phycocyanin concentrations - showed patterns consistent with elevated cyanobacteria in each year from 2012 to 2014; however, patterns were not mutually consistent. Ultimately, the continuous phycocyanin data were used as the primary descriptor of cyanobacteria in Willow Creek Lake. All three cyanobacteria datasets are provided in Hall and others (2018).

\section{Microcystins at the Swimming Beach}

Between 2006 and 2014, microcystin was detected at the swimming beach each year and exceeded the alert level of $20 \mu \mathrm{g} / \mathrm{L}$ (Brakhage, 2009) in 5 of 9 years, including 2013 and 2014 (fig. 2). Microcystins are typically near the $0.15 \mathrm{ug} / \mathrm{L}$ detection level at the beginning of the recreational season (starting in May) and peak sometime after July 1 of each year. The highest sampled microcystin concentration of $58.87 \mu \mathrm{g} / \mathrm{L}$ was in 2011, though the samples in 2010 and 2013 were not diluted and were thus only known to be greater than the analytical maximum of $35 \mu \mathrm{g} / \mathrm{L}$ (fig. 2). In most years, microcystin varied temporally, which can be explained in part by the dynamic nature of algal populations. Another characteristic of the data that may explain the microcystin fluctuations is the location of the beach site where the microcystin data were collected. Winds can lead to irregular distributions of cyanobacteria in a lake (Graham and others, 2008), and these wind-driven effects are more likely along the shore of the lake, such as at the beach site, than in the middle of the lake. In the summer, predominant winds for the region are southerly, which, on windy days, would push cyanobacteria away from the beach site on the southern shore of the lake. In fact, the median 




Figure 2. Weekly microcystin concentrations at the swimming beach of Willow Creek Lake (beach site; fig. 1; table 1). Data are from Nebraska Department of Environmental Quality (2015) and Hall and others (2018).

southerly component of the winds on days of microcystin samples from July-September was 5.9, 4.0, and $-0.2 \mathrm{mi} / \mathrm{h}$ in 2012 , 2013, and 2014, respectively. These southerly winds in 2012 may have contributed to the low microcystin concentrations observed then. This potential sensitivity to wind direction may suggest that the beach site, though important for assessing the exposure risks for recreational swimmers, may not be an ideal location for representing cyanobacteria concentrations for the entire lake.

\section{Algal Community Structure}

The 2014 algal community of Willow Creek Lake in 2014 was dominated by diatoms early in the season (through May), with several other algal taxa being present in lesser amounts (table 3), which is typical for Nebraska lakes (Thomas, S.A., Singh, C., and Hoagland, K., University of Nebraska-Lincoln, written commun., 2013). Cyanobacteria began to represent a substantial part of the phytoplankton biovolume in May (21 percent). Beginning in June 2014 and lasting for the remainder of the summer, cyanobacteria represented at least 86 percent of the total phytoplankton biovolume of the lake. Two samples from late summer 2013 had similar dominance, with cyanobacteria comprising at least 67 percent of the total phytoplankton biovolume. All samples with substantial cyanobacterial dominance (all except April 2014) had Microcystis as the most abundant genera, often representing more than 50 percent (and as much as 80 percent) of the biovolume of the phytoplankton community. The microcystin cyanotoxin is produced by Microcystis genera (although it should be noted that other genera produce microcystin as well), making its presence in the algal community relevant to the understanding of microcystin in the lake (Chorus and Bartram, 1999). The relation between the sampled microcystin concentrations and Microcystis is explored in the "Comparing the Three Measures of Cyanobacteria" section. Other genera that represented substantial members of the cyanobacteria community included Anabaena and Aphanizomenon.

\section{Phycocyanin}

Phycocyanin (a pigment unique to cyanobacteria and red algae) reached its highest density in 2013, followed by 2012 and 2014 (fig. 3; table 4). Most phycocyanin activity was during middle to late summer of each year. Phycocyanin exhibited a multipeak pattern in all three study years, with early growth in June leading to the first peak in early July, followed by a decreasing trend into August, a transition into renewed growth, and a second peak that varied between late August (2013 and 2014) and late September (2012).

Phycocyanin densities generally were not vertically stratified in 2012 and 2013 when measurements at multiple depths 
Table 3. Algal community biovolumes near the swimming beach of Willow Creek Lake (beach site; fig. 1; table 1), Nebraska, 2013-14.

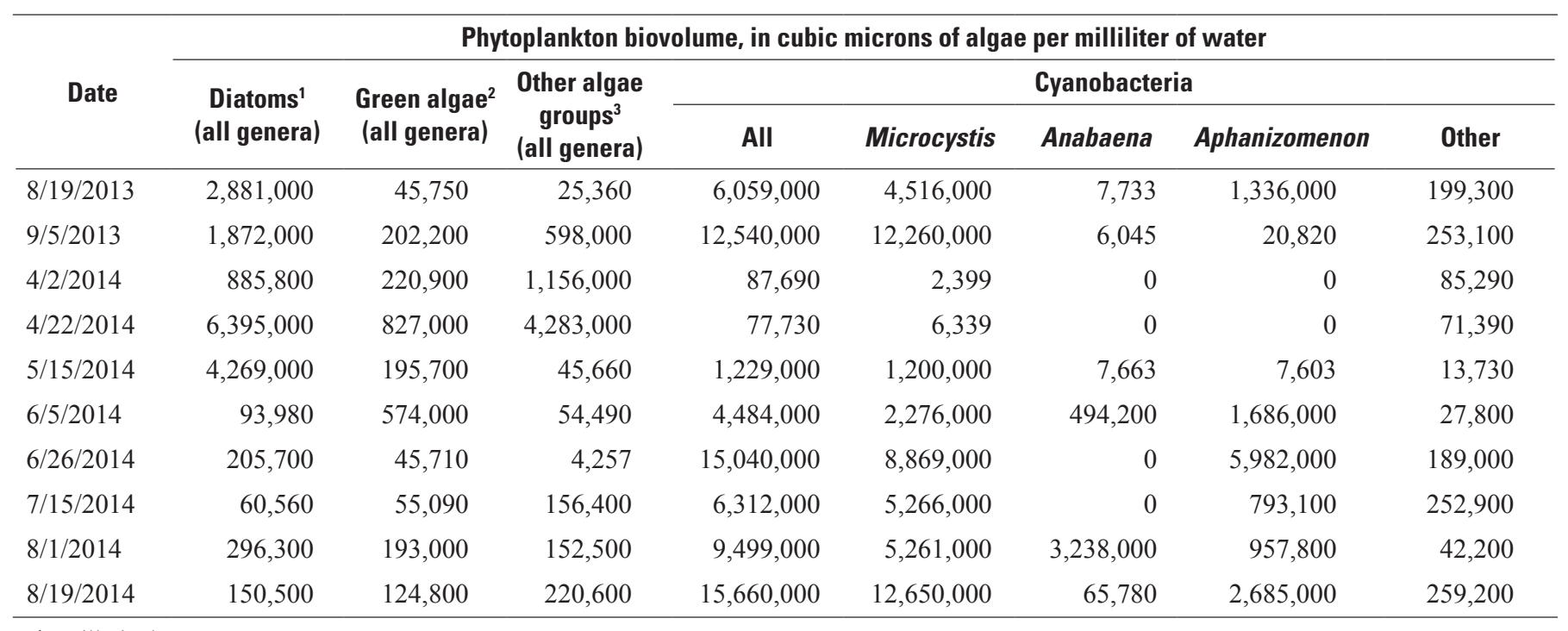

${ }^{1}$ Bacillariophyceae.

${ }^{2}$ Chlorophyta.

${ }^{3}$ Chrysophyta, Cryptomonadales, Haptophyta, Pyrrophycophyta, and Euglenophycota.

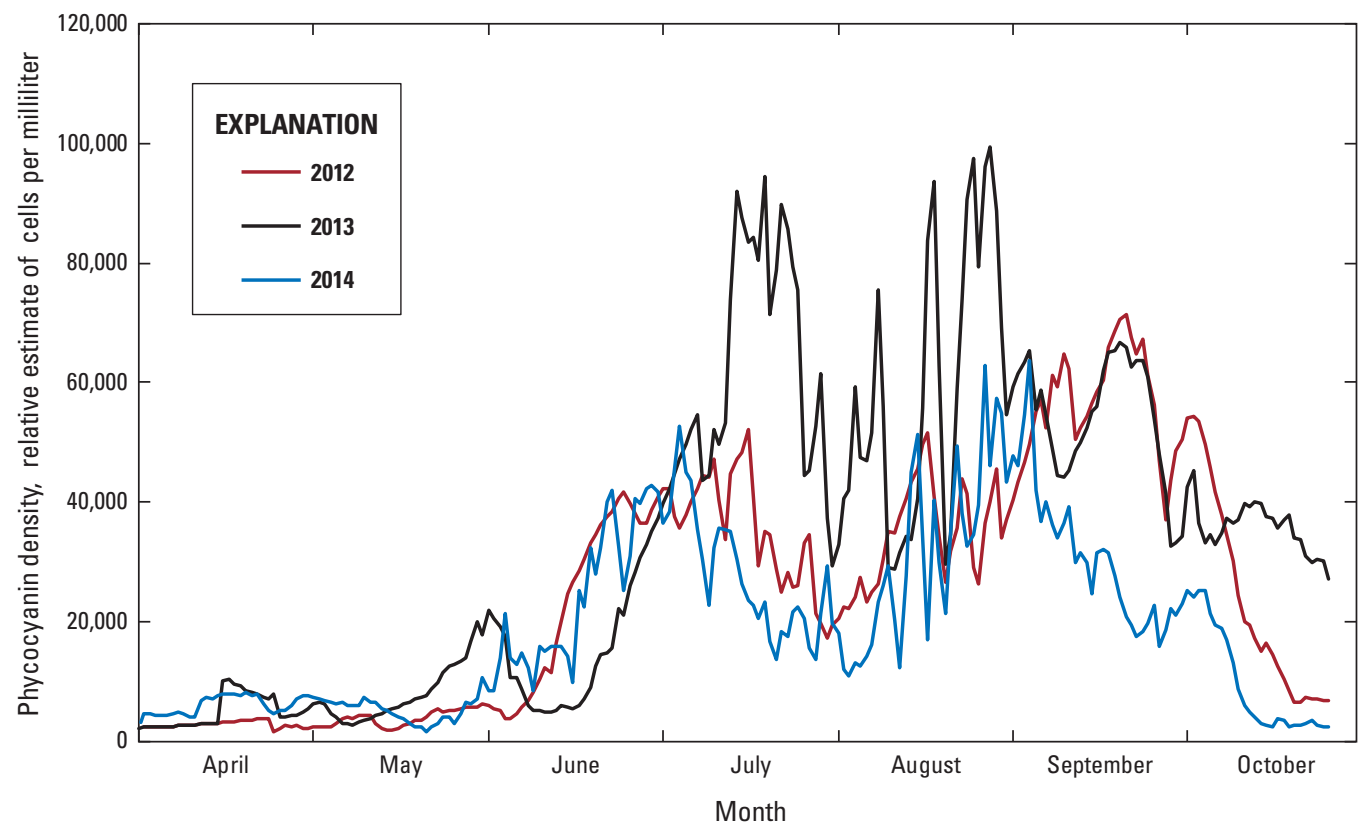

Figure 3. Phycocyanin density 1.6 feet beneath the water surface at the profiler site of Willow Creek Lake, Nebraska, 2012-14. 
Table 4. Summary of phycocyanin density from 1.6 feet beneath the water surface at the profiler site of Willow Creek Lake, Nebraska, 2012-14.

[All densities are given as relative indices of cells per milliliter using a vendor-derived algorithm from YSI, Incorporated (2011)]

\begin{tabular}{|c|c|c|c|c|c|c|c|c|c|c|}
\hline \multirow[b]{2}{*}{ Year } & \multirow{2}{*}{$\begin{array}{c}\text { Annual } \\
\text { maximum } \\
\text { phycocyanin } \\
\text { density }\end{array}$} & \multirow{2}{*}{$\begin{array}{c}\text { Annual } \\
\text { minimum } \\
\text { phycocyanin } \\
\text { density }\end{array}$} & \multicolumn{8}{|c|}{ Mean monthly phycocyanin density } \\
\hline & & & March & April & May & June & July & August & September & Octobe \\
\hline 2012 & 71,300 & 1,500 & 1,770 & 2,810 & 3,720 & 21,700 & 36,800 & 33,200 & 55,800 & 24,600 \\
\hline 2013 & 99,500 & 1,490 & 1,750 & 4,810 & 7,000 & 13,400 & 61,200 & 56,000 & 58,500 & 35,400 \\
\hline 2014 & 63,800 & 1,490 & 1,750 & 5,720 & 5,160 & 20,900 & 29,700 & 28,500 & 34,300 & 11,200 \\
\hline
\end{tabular}

were made. Mean relative standard deviation (RSD) of the phycocyanin profiles was 0.091 in 2012 , and only 0.4 percent of those RSDs exceeded an arbitrary threshold of 0.5. In 2013, mean phycocyanin RSD was 0.13 , and 5.5 percent of the RSDs exceeded 0.5 . There were short periods of phycocyanin stratification, primarily in August 2013, but they were typically short-lived (less than 1 week). Profiles of phycocyanin on 2 consecutive days are shown in figure 4 , which illustrates the more typical, unstratified conditions of August 19, 2013 (RSD at 14:00 was 0.087), as well as infrequent stratification conditions present on August 20, 2013 (RSD at 14:00 was 0.526). The lack of stratification suggests that vertical mixing processes in Willow Creek Lake may have overwhelmed the ability of the cyanobacteria population to regulate their vertical position within the water column to more optimal conditions for their growth and proliferation. A paired t-test (Helsel and Hirsch, 2002) comparison of logarithm-transformed phycocyanin at a depth of $1.6 \mathrm{ft}$ beneath the water surface with those averaged across all depths for all profiles measured during 2012 and 2013 indicated the two datasets were not significantly different ( $p$-value $=0.178$ ). As a result, subsequent analyses used near-surface phycocyanin density to represent

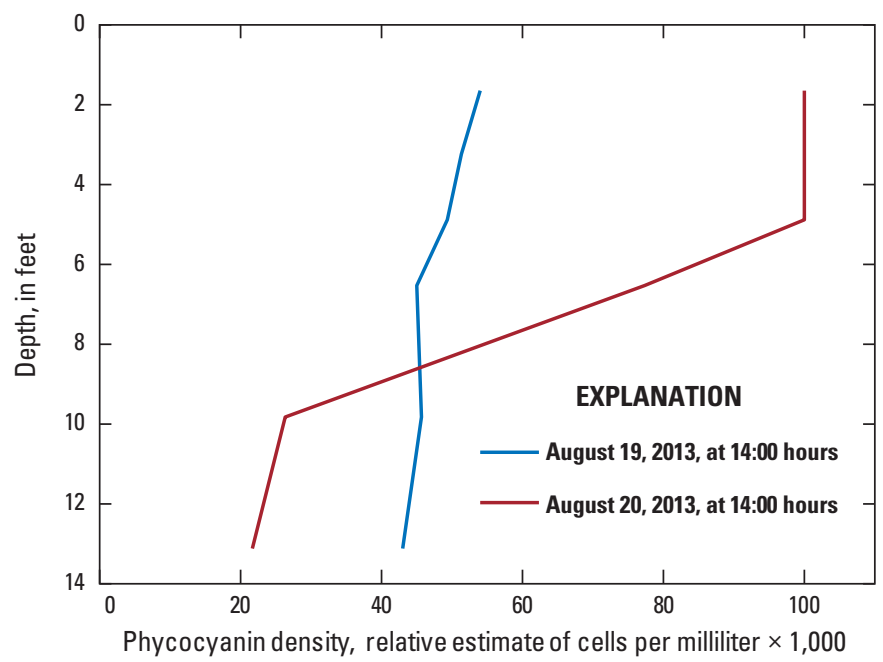

Figure 4. Vertical profile of phycocyanin density on August 19 and 20, 2013, at the profiler site, Willow Creek Lake, Nebraska. cyanobacterial concentrations in the lake. The phycocyanin measurements for all the depths are provided in Hall and others (2018).

\section{Comparing the Three Measures of Cyanobacteria}

A single metric for representing the cyanobacteria community during the study period was needed for making comparisons to the physicochemical factors. The 10 cyanobacterial community samples from 2013 to 2014 were not adequate for representing the entire study period but were used to assess the representativeness of the phycocyanin and microcystin data. Comparisons of cyanobacterial data suggested that the microcystin data may have been asynchronous with the cyanobacterial community and phycocyanin data (fig. 5). The comparisons were made by grouping the data by the dates of sample collection, or in the case of the microcystin and algal community data, the groupings were to the nearest day of one another.

In 2013 and 2014, microcystin concentrations were only approximately associated with the phycocyanin readings and were not associated with the 2012 phycocyanin data (fig. 5A). The algal community sample cyanobacteria biovolume and phycocyanin density were positively associated (fig. $5 B$ ). The association between cyanobacteria biovolume and the weekly microcystin concentrations of the lake was poor (fig. 5C). This might be a result of varying production of the microcystin toxin at different times of year or from different strains of cyanobacteria (Bozarth and others, 2010). Microcystin and biovolume samples were collected at a localized, recreational area of the lake and may not be representative of the entire lake; phycocyanin density data collected at the profiler site (fig. 1) may be more likely to represent the general cyanobacteria condition of the lake. For this reason, the phycocyanin data were used as an appropriate proxy for cyanobacteria in Willow Creek Lake and were included in comparisons to several factors that may be affecting cyanobacteria concentrations. 




in relative estimates of cells per milliliter

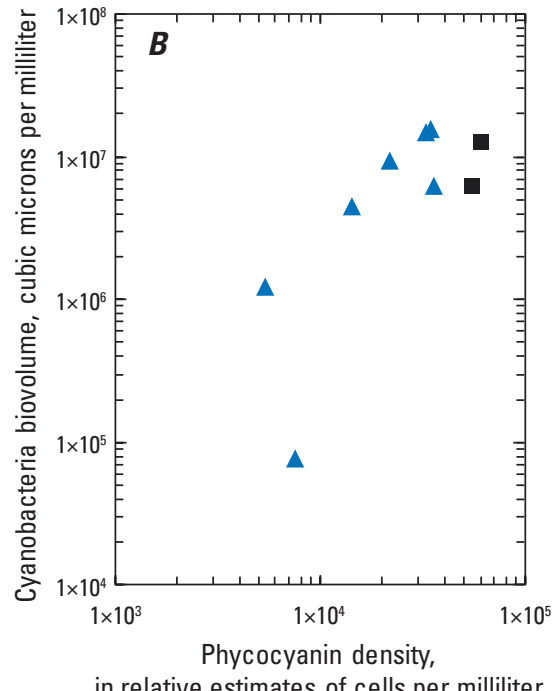

in relative estimates of cells per milliliter

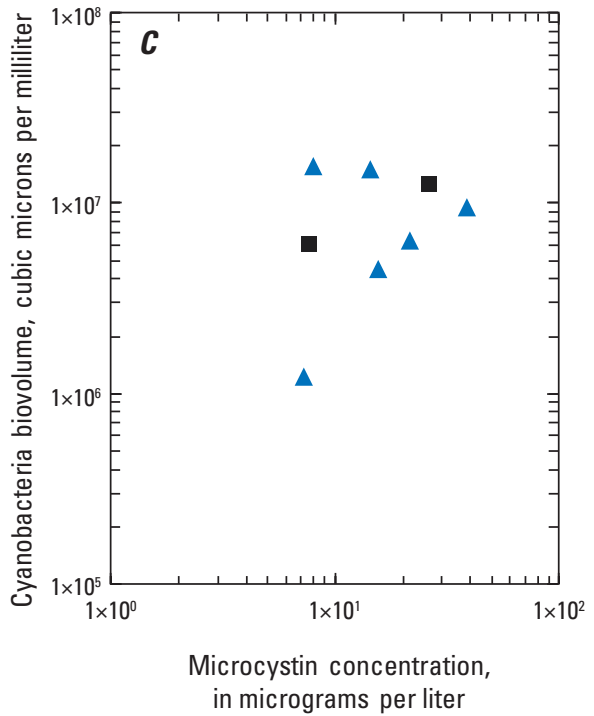

in micrograms per liter

EXPLANATION

- $2012 \square 2013 \quad \triangle 2014$

Figure 5. Intercomparisons of cyanobacteria metrics collected from the profiler and beach sites of Willow Creek Lake, 2012-14. $A$, phycocyanin density and microcystin concentration. $B$, phycocyanin density and cyanobacteria biovolume. $C$, microcystin concentration and cyanobacteria biovolume.

\section{Physicochemical Water-Quality Properties of Willow Creek Lake}

The physical and chemical characteristics, primarily the nutrient loading, of Willow Creek Lake (fig. 1) were assessed for the 2012-14 study period. During this study the external nutrient load from surface waters dominated the nutrient balance, with magnitudes much larger than the groundwater contribution or internal nutrient cycling. The data that were compiled to inform the physicochemical characteristics of Willow Creek are provided in Hall and others (2018).

\section{Hydrology and External Nutrient Loading}

The external nutrient loading to Willow Creek Lake was a function of the flow components into and out of the lake and the corresponding nutrient concentrations in those flow components. Using a water-balance approach in conjunction with sampling data, daily loads of nitrate plus nitrite as nitrogen, total Kjeldahl nitrogen, total phosphorus, and phosphate (NO3, $T K N, T P$, and $P O 4$, respectively) supplied to Willow Creek Lake were calculated for this study for the period of March 2012 to October 2014. Results showed that the major source of nutrients was the main stem of Willow Creek; substantial amounts of $T K N, T P$, and $P O 4$ also originated from the NT subbasin.

\section{Water Balance Components}

A water balance of Willow Creek Lake derived for the 2012-14 study period estimated that the major inflow component to the lake was from the Foster site (fig. $6 A$ ) and the major outflow was groundwater flux (fig. 6B; table 5). Groundwater flowed into and out of the lake during the study but had a net outflow (table 5). Surface inflow components were characterized by spring runoff that transitioned into base-flow conditions in the summer for 2012 and 2013 but were more evenly distributed through 2014 (fig. 6C). Surface outflow from the lake ceased on June 14, 2012, when the lake elevation dropped below the spillway elevation and continued to remain below the spillway for the remainder of the study (table 5). Before that, the surface outflow composed a large part of the monthly water balance for that early period.

\section{Differences in Streamflow Characteristics Between the Sites}

Streamflows at the NT site were generally more responsive to rainfall and runoff than were those at the Foster or ST sites. The Richards-Baker flashiness index (Baker and others, 2004) - a unitless measure of the rate of daily streamflow change relative to the overall streamflow, that varies from 1 for highly flashy to zero for a lack of flashiness - was much larger at the NT site (0.44) than at either the Foster $(0.15)$ or ST (0.24) sites. Some of this difference may be because of differences in drainage areas, but the larger flashiness at NT 



Figure 6. Inflows and outflows of Willow Creek Lake, Nebraska, 2012-14. All outflows, including groundwater flux, are represented as negative values. $A$, total inflow. $B$, total outflow. $C$, monthly inflow and outflow. 
Table 5. Water balance summaries (inflows and outflows) for Willow Creek Lake, Nebraska, 2012-14.

[Foster, Willow Creek near Foster; NT, North Tributary to Willow Creek Lake; ST, South Tributary to Willow Creek Lake; P, precipitation; $\Delta \mathrm{S}$, change in lake storage volume (negative values of $\Delta \mathrm{S}$ represent decreases in storage); Outflow, Willow Creek near Pierce; E, evaporation; GW, groundwater flux (negative values of GW represent a net flux into the lake from the GW)]




Table 5. Water balance summaries (inflows and outflows) for Willow Creek Lake, Nebraska, 2012-14.—Continued

[Foster, Willow Creek near Foster; NT, North Tributary to Willow Creek Lake; ST, South Tributary to Willow Creek Lake; P, precipitation; $\Delta \mathrm{S}$, change in lake storage volume (negative values of $\Delta \mathrm{S}$ represent decreases in storage); Outflow, Willow Creek near Pierce; E, evaporation; GW, groundwater flux (negative values of GW represent a net flux into the lake from the GW)]

\begin{tabular}{|c|c|c|c|c|c|c|c|c|c|}
\hline \multirow{2}{*}{ Start date } & \multirow{2}{*}{ End date } & \multicolumn{4}{|c|}{ Inflow, in acre feet } & \multicolumn{4}{|c|}{ Outflow, in acre feet } \\
\hline & & Foster $^{1}$ & $\mathbf{N T}{ }^{1}$ & $\mathbf{S T}^{1}$ & $\mathbf{P}$ & $\Delta \mathbf{S}$ & Outflow $w^{1,2}$ & $E$ & GW \\
\hline \multicolumn{10}{|c|}{ Study totals } \\
\hline
\end{tabular}

${ }^{1}$ Site described in table 1 and shown in figure 1.

${ }^{2}$ Outflow was set to 0 beginning on June 14, 2012, when the lake elevation dropped below the spillway elevation.

${ }^{3}$ Note that the values for the first water year only reflect 7 months (or 214 days) of data collection. The water year is the continuous 12 -month period from October 1 through September 30 and is designated by the year in which it ends.

as compared with the smaller ST site suggests that infiltration rates in the NT basin may be lower than the rest of the basin, likely because of higher amounts of silt and clay in NT basin soils (Natural Resources Conservation Service, 2011).

\section{Lake-Groundwater Interaction}

An analysis by Nickel Engineering (2012) of historical water-level data from the monitoring and pressure-relief wells on the dam and wells in the High Plains aquifer indicated that Willow Creek Lake was typically in direct connection with the upper part of the High Plains aquifer system, with groundwater levels in shallow wells often higher than the lakebed elevation near the spillway. Additionally, deep wells generally had a higher-pressure head than the shallow wells, leading to a condition where the upper part of the aquifer gained water from the deeper part by water flowing through the local confining layer. The upper part of the aquifer then interacted with the lake, alternately contributing and receiving seepage depending on the current condition of the hydrologic system.

Pressure-relief wells along the downstream edge of the dam return groundwater back to the creek downstream from the dam. As mentioned earlier, streamflow at the outflow site persisted for much of the study despite the lake level dropping below the spillway elevation, and this persistence was attributed to the contribution from the pressure-relief wells. To isolate the surface outflows, the flow measurements at the outflow site were adjusted to account for the contributions from the pressure-relief wells by reducing flow by $4 \mathrm{ft}^{3} / \mathrm{s}$ before the spillway went dry on June 14, 2012, and zeroing the flow thereafter (table 5). The cumulative volume of water associated with this adjustment was more than 5,700 acre-ft during the 3-year study. However, because of the deep screen depths of the pressure-relief wells, Nickel Engineering (2012) asserted that some of the flow was a result of the upwards head gradients in the deeper parts of the aquifer and not exclusively because of seepage from the lake.

Because of the interconnection of the surface water and groundwater around Willow Creek Lake, the drought in 2012 had several effects on the entire system. Water levels in the upper and deeper part of the aquifer dropped below the lakebed elevation, causing large losses of lake water to groundwater for much of the study. The combination of decreases in precipitation, stream inflow, and groundwater level led to a substantial lake level decrease, and lake storage decreased from greater than 7,000 acre-ft to less than 2,600 acre-ft during early June to early October 2012. Additionally, the water surface area of the lake decreased from 740 acres to less than 230 acres during that period.

\section{Sampling Results}

More than 200 water-quality samples from 4 surfacewater sites, 12 samples from 12 groundwater sites, and 106 lake samples were collected or compiled from other sources for inclusion in the analysis (Hall and others, 2018). Surface-water sampling began on June 29, 2012; by that time, outflow from the lake had ceased and did not resume for the remainder of the study period. Because of this, outflow samples were not collected for nutrient analysis. The highest mean concentration for $\mathrm{NO}_{3}(11.4 \mathrm{mg} / \mathrm{L})$ was observed at the ST site, whereas the highest mean concentrations for all other nutrients (TKN, TP, and $\mathrm{PO}_{4}$ ) were observed at the NT site (table 6).

Paired t-tests of concentration differences between the 9 samples from the upstream site and samples collected at the Foster site on the same day (usually within 1 hour) were used to determine if the nutrient concentrations were significantly different (at a threshold $p$-value of 0.05) between the Foster site and the flow entering the lake. Differences in the concentrations of TKN, TP, and $\mathrm{PO}_{4}$ were not significant; however, $\mathrm{NO}_{3}$ concentrations were significantly $(p$-value $=0.004)$ larger at the Foster site, with an average concentration in the paired samples of $10.4 \mathrm{mg} / \mathrm{L}$ as compared with the average concentration of $9.46 \mathrm{mg} / \mathrm{L}$ at the upstream site. This difference in concentrations from two nearby sites on the same days may be the result of biological uptake of $\mathrm{NO}_{3}$ by algae and plants in the stream and riparian zone or dilution from streamflow and groundwater. Although the average $\mathrm{NO}_{3}$ concentration 
Table 6. Chemical sampling summary for stream and groundwater sites in Willow Creek Basin, Nebraska, 2012-14.

[Foster, Willow Creek near Foster; NT, North Tributary to Willow Creek Lake; ST, South Tributary to Willow Creek Lake; Upstream, Willow Creek upstream from Willow Creek Lake; GW, compilation of data from the 12 groundwater sites used in this study; Deep, Willow Creek Lake chemistry; Grab, collected manually using grab-sampling techniques; Auto, collected using an automatic sampler; mg/L, milligrams per liter; $\mathrm{NO}_{3}$, nitrate as nitrogen; TKN, total Kjeldahl nitrogen as nitrogen; --, no analyses; TP, total phosphorus as phosphorus; $\mathrm{PO}_{4}$, phosphate as phosphorus; <, less than.]

\begin{tabular}{|c|c|c|c|c|c|c|}
\hline \multirow{2}{*}{$\begin{array}{c}\text { Sample type or } \\
\text { constituent }\end{array}$} & \multicolumn{6}{|c|}{ Site (table 1; fig. 1) } \\
\hline & Foster & NT & ST & Upstream & GW & Deep \\
\hline \multicolumn{7}{|c|}{ Number of samples } \\
\hline Grab & 21 & 14 & 13 & 10 & 12 & 15 \\
\hline Auto & 34 & 51 & 0 & 0 & 0 & 0 \\
\hline Total & 55 & 65 & 13 & 10 & 12 & 15 \\
\hline \multicolumn{7}{|c|}{ Maximum concentration, in milligrams per liter } \\
\hline $\mathrm{NO}_{3}$ & 15.80 & 15.00 & 15.30 & 15.30 & 3.7 & 5.56 \\
\hline TKN & 2.97 & 5.19 & 2.30 & 2.32 & -- & 2.42 \\
\hline TP & 1.44 & 1.79 & 0.46 & 0.44 & -- & 0.14 \\
\hline $\mathrm{PO}_{4}$ & 0.32 & 1.30 & 0.35 & 0.20 & 0.176 & $<0.02$ \\
\hline \multicolumn{7}{|c|}{ Mean concentration, in milligrams per liter } \\
\hline $\mathrm{NO}_{3}$ & 7.00 & 5.77 & 11.4 & 9.46 & 0.75 & 2.15 \\
\hline TKN & 2.03 & 2.53 & 1.11 & 1.44 & -- & 1.49 \\
\hline TP & 0.41 & 0.82 & 0.21 & 0.30 & -- & 0.088 \\
\hline $\mathrm{PO}_{4}$ & 0.14 & 0.51 & 0.14 & 0.13 & 0.085 & $<0.02$ \\
\hline \multicolumn{7}{|c|}{ Minimum concentration, in milligrams per liter } \\
\hline $\mathrm{NO}_{3}$ & 1.81 & 1.89 & 6.40 & 1.81 & $<0.2$ & $<0.05$ \\
\hline TKN & $<0.50$ & 0.56 & 0.52 & $<0.50$ & -- & 1.05 \\
\hline TP & 0.09 & 0.12 & 0.07 & 0.11 & -- & 0.050 \\
\hline $\mathrm{PO}_{4}$ & $<0.05$ & 0.05 & $<0.05$ & 0.06 & $<0.05$ & $<0.02$ \\
\hline
\end{tabular}

over time was higher at the upstream site than the Foster site (table 6), this may be an artifact of the limited sampling at the upstream site, which did not include high streamflow (that was typically of a lower $\mathrm{NO}_{3}$ concentration) captured by the automatic sampler at the Foster site. Despite this difference, the Foster streamgage and nutrient data were used to compute nutrient loads to the lake, in part because the upstream site lacked streamflow data and high-streamflow samples.

To determine how well the sample data represent the range of possible flow conditions during the study, flow duration curves were developed for all three stream monitoring sites (Foster, NT, and ST; fig. 7). These curves show the percentage of time that streamflow at the site exceeds a particular rate. For streams that rise and fall rapidly in response to precipitation, routine sampling at regular intervals often underrepresents high flows. To account for the potential for undersampling high flows, automatic samplers were deployed at the Foster and NT sites. The sample points in figure 7 show that the automatic samplers were effective in collecting samples during the short periods of high flow, whereas the routine manual sampling at the ST site was effective in collecting samples over the range of lower-flow conditions. The lack of infrastructure at the ST site prevented the deployment of an automatic sampler, but the combination of routine sampling and visits during runoff was adequate to represent the range of flow conditions in this base-flow dominated subbasin.

\section{External Nutrient Loading}

The nutrient load being supplied to the lake was calculated from flow or seepage flux and nutrient sampling data. Loads were calculated for March 1, 2012, through September 30, 2014, for all three stream monitoring sites (Foster, NT, and ST) using the LOADEST model (Runkel and others, 2004), and groundwater loads were calculated from the daily flow and lake and groundwater nutrient concentrations as detailed earlier in the "Characterization of Physicochemical Water-Quality Properties Within the Willow Creek Basin" section. Loads calculated at the NT site had higher uncertainty than the other stream sites, presumably as a result of greater flashiness at the site relative to the other two. The load uncertainty at the NT site was particularly high with the sediment-associated nutrients of $\mathrm{TKN}, \mathrm{TP}$, and $\mathrm{PO}_{4}$, with the average standard error being nearly equal to the average daily load (see a more detailed description 



EXPLANATION

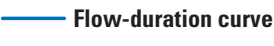

+ Sample

Figure 7. Distribution of discrete samples in relation to flow-duration curves for three stream sampling sites, Nebraska, June 2012-August 2014. A, Willow Creek near Foster (Foster site; autosampler equipped). B, North Tributary to Willow Creek Lake (NT site; autosampler equipped). C, South Tributary to Willow Creek Lake (ST site). 
in appendix 1). The greatest amounts of uncertainty were associated with the early spring periods, implying that the first flush of sediments from the ephemeral stream were dynamic and had a detrimental effect on the model performance. Although direct estimates of load models were used in comparisons, the effect of uncertainty on those loads was considered when interpreting them. Stream loads contributed the most nutrients to the lake, whereas nutrient losses from the lake were comparatively smaller and were during times of seepage losses to the groundwater system (fig. 8; table 7).

During the 31 months of the study, there was a net inflow of 182 tons of $\mathrm{NO}_{3}$ to Willow Creek Lake (table 7; fig. 8A). $\mathrm{NO}_{3}$ loads were dominated by the main stem of Willow Creek, with the high flows and concentrations recorded at the Foster site providing 194 tons (plus or minus $[ \pm] 13$ percent average standard error) of $\mathrm{NO}_{3}$ during the study. The smaller streams (NT and ST sites) contributed minimal amounts of $\mathrm{NO}_{3}$ to the lake during the study, with 5.52 tons ( \pm 22 percent) from the NT site and 3.95 tons ( \pm 52 percent) from the ST site. The net $\mathrm{NO}_{3}$ flux between the lake and groundwater resulted in an outflow of 21.3 tons. Groundwater flux was into the lake during 25 percent of the study. The remainder of the study was characterized by groundwater outflow, from which the outgoing $\mathrm{NO}_{3}$ flux was estimated using the lake $\mathrm{NO}_{3}$ concentration. Because of the seasonal characteristics of $\mathrm{NO}_{3}$ in the lake, the concentration was represented with a two-component equation (eq. 2): (1) an ordinary least squares regression of $\mathrm{NO}_{3}$ with a sine transformation of the Julian day associated with lake samples collected before August of each of the 3 study years (samples collected after August 1 were excluded from this regression because of the presence of sample data below the detection limit); and (2) an assumed concentration of zero in place of negative values predicted by the regression corresponding to the period between August 8 and November 16 .

$$
N O_{3} \text { res }=\left\{\begin{array}{l}
3.46 \sin D+2.18 \\
\text { for } D<200 \text { and } D>320 \\
0, \text { for } 220<D<320
\end{array}\right.
$$

where

$$
\begin{gathered}
\mathrm{NO}_{3-} \text { res } \begin{array}{c}
\text { is the predicted lake concentration of } \mathrm{NO}_{3} \text {, in } \\
\text { milligrams per liter; and }
\end{array} \\
\text { is the Julian day of the year (values of } 220 \\
\text { and } 320 \text { correspond to August } 8 \text { and } \\
\text { November 16, respectively). }
\end{gathered}
$$

TKN load sources were primarily split between the Foster and NT site subbasins, and these loads were substantially lower than $\mathrm{NO}_{3}$. The Foster site recorded the highest load, contributing 24.3 tons ( \pm 7.8 percent), whereas the NT site recorded a TKN load of 19.0 tons ( \pm 80 percent; table 7 ). The ST site subbasin contributed only 0.85 tons ( \pm 21 percent) of TKN. Because most components of TKN are either in particulate form or are sorbed to sediment particles, it was not considered to be a part of the groundwater interaction with the lake and the net seepage load was assumed to be zero. The total net inflow of TKN load to the lake during the study was 44.2 tons (table 7; fig. 8A). The total nitrogen load to the lake was 226 tons during the study, of which about 80 percent was in the form of $\mathrm{NO}_{3}$.

$\mathrm{PO}_{4}$ load was larger at the NT site despite having less streamflow than the Foster site. The Foster site contributed a $\mathrm{PO}_{4}$ load of 1.55 tons ( \pm 14 percent), whereas the NT site contributed an average of 2.42 tons ( \pm 69 percent) of $\mathrm{PO}_{4}$. The ST site also was a minor contributor in the $\mathrm{PO}_{4}$ load, with 0.103 tons ( \pm 23 percent). Based on lake nutrient concentrations, there was assumed to be no $\mathrm{PO}_{4}$ leaving the lake during times of water loss to groundwater, and as such the net groundwater load of $\mathrm{PO}_{4}$ into Willow Creek Lake during the study ( 0.218 tons; table 7 ; fig. $8 B$ ) was greater than that from the ST site.

The TP load to Willow Creek Lake, which includes the inorganic $\mathrm{PO}_{4}$ and organic sources of phosphorus, was largely balanced between the Foster and NT sites. At 4.49 tons ( \pm 5.7 percent), the Foster site subbasin likely was the highest contributor of TP to the lake, whereas the NT site contributed 3.56 tons ( \pm 90 percent) of TP. The ST site only contributed 0.159 tons ( \pm 24 percent) of TP. All TP contributed to the lake from inflowing groundwater was $\mathrm{PO}_{4}$ and totaled 0.218 tons. The overall total load of TP to the lake during the study was 8.42 tons, about one-half of which was in the form of $\mathrm{PO}_{4}$.

Nutrient loads had a strong seasonal pattern (figs. $8 C$ and $8 D$ ) that mirrored streamflow patterns (fig. 6). High flows in the spring contributed the most nutrient load to Willow Creek Lake during the months of March-June, particularly in 2012 and 2013. Given the uncertainty in some of the load models, especially at the NT site, the magnitude of the loads may be quite different from these estimates, but relative contribution of nutrients from spring runoff is likely important nonetheless. The pattern in 2014 was different; external nutrient loads peaked in the spring but maintained a higher amount of load throughout the summer.

Average nutrient loads were normalized by dividing the load by the drainage area to obtain subbasin mean annual nutrient yields (table 7). The yields are similar between the Foster and ST site subbasins, but the NT site subbasin seems to contribute nutrients differently. $\mathrm{NO}_{3}$ yields are much larger from the Foster and ST site subbasins, whereas TKN, TP, and $\mathrm{PO}_{4}$ yields are much higher from the NT site subbasin. Whereas $\mathrm{NO}_{3}$ is water soluble, TKN, TP, and $\mathrm{PO}_{4}$ typically exist either in particulate form or are sorbed to the surface of sediment particles. Therefore, these differences in yields might be explained by differences in transport mechanisms between the NT site subbasin and the Foster and ST site subbasins. Differences in land use and soil types were explored as potential explanations for these differences. Prior literature (Spalding and others, 1992; Whiles and others, 2000) did not indicate substantial differences in land use among the subbasins. In addition, the percentage of cultivated crops in each of the subbasins using 2011 land cover data (U.S. Department of Agriculture, 2014) was not substantially different, with cropland occupying 65,70 , and 73 percent of the subbasin 

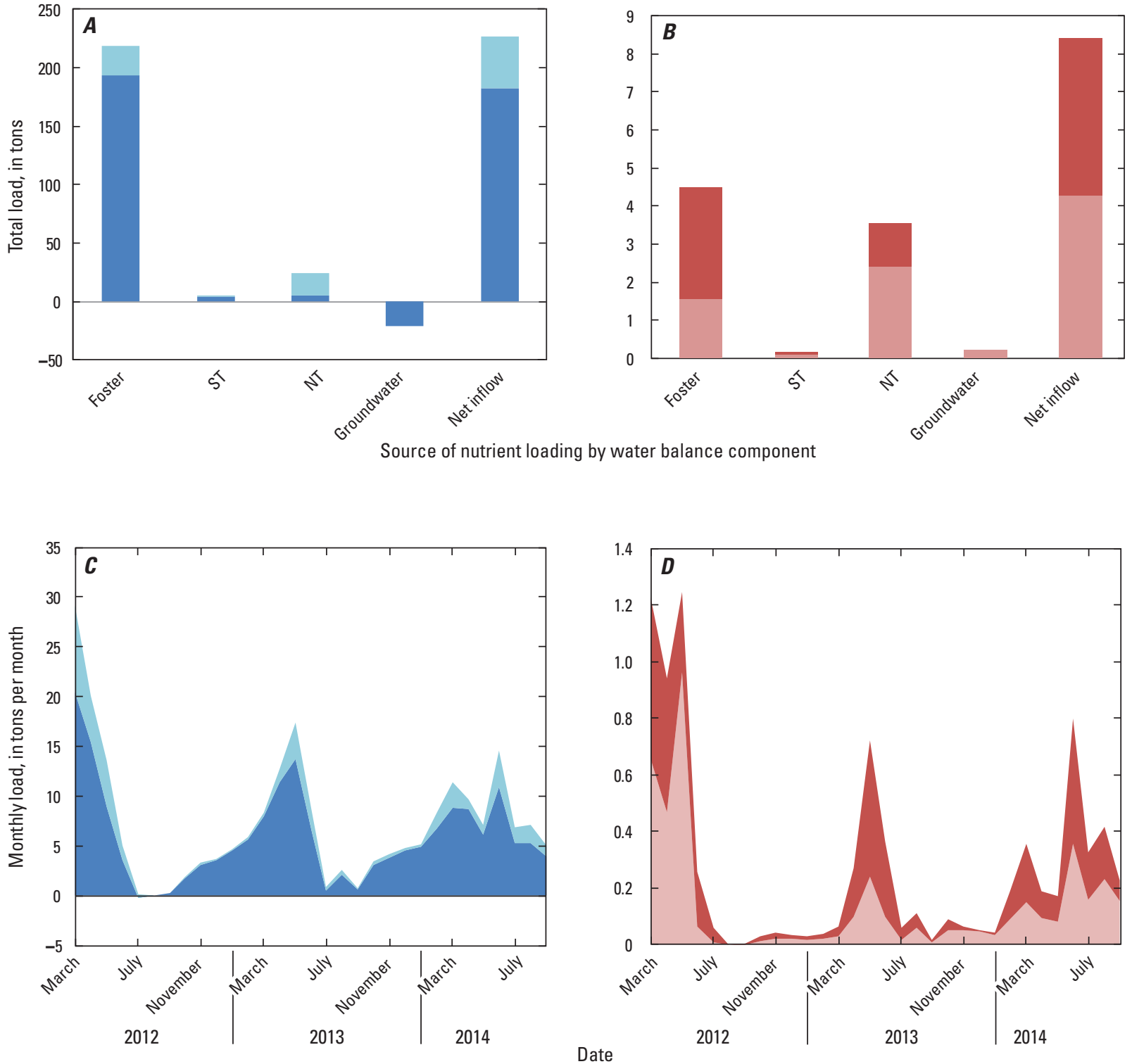

\section{EXPLANATION}

[Foster, Willow Creek near Foster; ST, South Tributary to Willow Creek Lake; NT, North Tributary to Willow Creek Lake]

\section{Nitrate as nitrogen \\ Phosphate as phosphorus \\ Total Kjeldahl nitrogen \\ Organic phosphorus}

Figure 8. External nutrient loading into Willow Creek Lake, Nebraska, 2012-14. Site locations are described in table 1 and shown in figure 1. $A$, total nitrogen species load, by water balance components. $B$, total phosphorus species load, by water balance components. $C$, monthly nitrogen species load of the net inflow to the lake. $D$, monthly phosphorus species load of the net inflow to the lake. 
Table 7. Total loading and mean annual yield into Willow Creek Lake, Nebraska, 2012-14.

[Foster, Willow Creek near Foster; ST, South Tributary to Willow Creek Lake; NT, North Tributary to Willow Creek Lake; GW, compilation of data from the 12 groundwater sites used in this study; $\mathrm{TN}$, total nitrogen; $\mathrm{NO}_{3}$, nitrate plus nitrite as nitrogen; TKN, total Kjeldahl nitrogen; TP, total phosphorus; $\mathrm{PO}_{4}$, phosphate as phosphorus; Org-P, organic phosphorus as phosphorus; --, not applicable]

\begin{tabular}{|c|c|c|c|c|c|}
\hline \multirow{2}{*}{ Constituent } & \multicolumn{5}{|c|}{ Site (table 1; fig. 1) } \\
\hline & Foster & ST & NT & GW & Net inflow \\
\hline \multicolumn{6}{|c|}{ Total load, in tons } \\
\hline $\mathrm{TN}$ & 218 & 4.80 & 24.6 & -21.3 & 226 \\
\hline $\mathrm{NO}_{3}$ & 194 & 3.95 & 5.52 & -21.3 & 182 \\
\hline TKN & 24.3 & 0.85 & 19.0 & 0 & 44.2 \\
\hline $\mathrm{TP}$ & 4.49 & 0.159 & 3.56 & 0.218 & 8.42 \\
\hline $\mathrm{PO}_{4}$ & 1.55 & 0.103 & 2.42 & 0.218 & 4.29 \\
\hline Org-P & 2.94 & 0.0562 & 1.14 & 0 & 4.13 \\
\hline \multicolumn{6}{|c|}{ Mean annual yield, in pounds per acre per year } \\
\hline $\mathrm{TN}$ & 1.71 & 1.42 & 1.41 & -- & 1.14 \\
\hline $\mathrm{NO}_{3}$ & 1.52 & 1.17 & 0.318 & -- & 0.916 \\
\hline TKN & 0.91 & 0.25 & 1.09 & -- & 0.222 \\
\hline ТP & 0.0352 & 0.0471 & 0.205 & -- & 0.0424 \\
\hline $\mathrm{PO}_{4}$ & 0.0121 & 0.0305 & 0.139 & -- & 0.0216 \\
\hline Org-P & 0.0231 & 0.0167 & 0.0653 & -- & 0.0208 \\
\hline
\end{tabular}

areas of the Foster, ST, and NT sites, respectively. In contrast, the soil erodibility $(K f)$ of the NT site subbasin was expected to differ from that of the Foster and ST site subbasins, based on the higher amounts of particulates observed in the NT site water samples and anecdotal observations of Whiles and others (2000). The area-weighted $K f$ values were determined to be $0.152,0.135$, and 0.171 at the Foster, ST, and NT site subbasins, respectively. The NT site has a higher likelihood of eroded materials, which may explain the higher yields of sediment-related nutrient species there.

\section{Internal Nutrient Loading}

The retention or release of nutrients into the water column from the sediment, also known as internal loading, is another source of nutrients to the lake water column, but its contribution is often less than the external loading of nutrients in agricultural landscapes (Song and others, 2017). Sediment cores collected from Willow Creek Lake in September 2013 and June 2014 were incubated for 7 days to assess potential for sediment to produce or consume water column phosphorus under aerobic (oxic) and anaerobic (anoxic) conditions; the oxic conditions served as a control, and the anoxic conditions represented typical lake sediment environments. Data resulting from these incubations are provided in Hall and others (2018). Sediment cores collected in triplicate from three different locations in the lake (fig. 1; tables 1 and 8) were characterized by modest, albeit varying, rates of nutrient release. The pattern of releases varied temporally between the 2013 and 2014 cores but generally did not vary spatially between the three locations. During the course of a given incubation, $\mathrm{PO}_{4}$ fluxes in the anoxic cores could generally be described by releases during the first $80-100$ hours followed by $\mathrm{PO}_{4}$ consumption for the remainder of the incubation (fig. 9). As a result, release rates were computed as the median of all measured release rates between 12 and 100 hours of incubation (table 8). The median $\mathrm{PO}_{4}$ release rate for all cores was $0.672 \mathrm{mg} \mathrm{P} / \mathrm{m}^{2} / \mathrm{d}$, which was low relative to published release rates from other lakes in Canada and the United States (Nürnberg, 1988; Nowlin and others, 2005).

Total dissolved phosphorus (TDP) fluxes from the anoxic sediment cores did not follow a consistent pattern of release or consumption. The 2013 cores indicated TDP was released, whereas the 2014 cores indicated a general consumption of TDP (fig. 10). TDP consumption under anoxic conditions contrasts with the expected release of TDP from anoxic sediments (Boström and others, 1988; Nürnberg, 1988; Søndergaard and others, 2001; Nowlin and others, 2005) and may not only suggest problems with the measurements of the 2014 cores but also may suggest a more complex geochemistry of those sediments. As a result, TDP release rates were computed only for the 2013 cores (table 8 ). The median TDP release rate of $2.32 \mathrm{mg} \mathrm{P} / \mathrm{m}^{2} / \mathrm{d}$ is low compared to eutrophic lakes and is more comparable to rates associated with mesotrophic lakes (Nürnberg, 1988; Welch and Coke, 1995). These rates also are in stark contrast to lakes in Lancaster County, Nebraska, where sedimentary TDP releases were several orders of magnitude higher (Thomas, S.A., Singh, C., and Hoagland, K., University of Nebraska-Lincoln, written commun., 2013). The reasons 
Table 8. Nutrient release rates measured from Willow Creek Lake sediment cores, Nebraska, 2013-14.

[Each core location included sediment cores collected in triplicate. $\mathrm{PO}_{4}$, phosphate as phosphorus; TDP, total dissolved phosphorus; --, not calculated]

\begin{tabular}{|c|c|c|c|}
\hline \multirow[t]{2}{*}{ Date } & \multirow{2}{*}{$\begin{array}{c}\text { Core } \\
\text { location } \\
\text { (fig. 1) }\end{array}$} & \multicolumn{2}{|c|}{$\begin{array}{l}\text { Median release rate, } \\
\text { in milligrams } \\
\text { per square meter per day }\end{array}$} \\
\hline & & $\mathrm{PO}_{4}$ & TDP \\
\hline $9 / 19 / 2013$ & Lower & 1.26 & 3.97 \\
\hline $9 / 19 / 2013$ & Middle & 1.09 & 5.95 \\
\hline 9/19/2013 & Upper & 0.519 & -0.85 \\
\hline $6 / 2 / 2014$ & Lower & 0.773 & -- \\
\hline $6 / 2 / 2014$ & Middle & 0.494 & -- \\
\hline $6 / 2 / 2014$ & Upper & 0.0901 & -- \\
\hline $\begin{array}{c}9 / 19 / 2013 \text { and } \\
6 / 2 / 2014\end{array}$ & All & 0.672 & 2.32 \\
\hline
\end{tabular}

for the low TDP and $\mathrm{PO}_{4}$ sedimentary release rates in Willow Creek are unclear, but the results suggest internal phosphorus loading to be a negligible component of the overall nutrient load to the lake.

\section{Nutrient Availability in the Lake}

Algal uptake uses inorganic forms of nitrogen and phosphorus for cell growth, although other forms of lake nitrogen and phosphorus also are ecologically relevant because of nutrient cycling. One inorganic form of nitrogen, ammonia, is included in TKN analyses for this study. However, ammonia oxidizes to $\mathrm{NO}_{3}$ when in oxic environments such as in the streams and most of the lake. Ammonia concentrations were likely negligible in stream and lake water, so focus was placed on $\mathrm{NO}_{3}$ and $\mathrm{PO}_{4}$ because they are the nutrient forms that were biologically available for algal uptake. As a result, dissolved inorganic nitrogen (DIN) was represented by $\mathrm{NO}_{3}$ concentrations and dissolved inorganic phosphorus (DIP) was represented by $\mathrm{PO}_{4}$ concentrations in the streams and lake.

Seasonal lake $\mathrm{NO}_{3}$ concentrations that had spring maxima and late summer minima were because of algal uptake. This association also was present in the monthly $\mathrm{NO}_{3}$ lake samples during 2012-14 that were used to predict daily $\mathrm{NO}_{3}$ concentrations using a seasonal component (the sine of the Julian day; appendix 1). In contrast, seasonal patterns in lake $\mathrm{PO}_{4}$ were not detectable because all the 2012-14 samples were below the $0.01 \mathrm{mg} / \mathrm{L}$ detection limit. Between 2000 and 2014, only 5 of $60 \mathrm{PO}_{4}$ samples were above $0.01 \mathrm{mg} / \mathrm{L}$, suggesting that the external loads of $\mathrm{PO}_{4}$ are used quickly by biota such as algae in Willow Creek Lake (Hall and others, 2018).

Algae need nitrogen and phosphorus for cell growth. Establishing which nutrients limit algal growth in Willow Creek Lake is useful because changes in the ratio of nitrogen to phosphorus can affect algal species composition. The molar ratio of 16 molecules of nitrogen for every molecule of phosphorus (Redfield ratio; Redfield and others, 1963) is commonly used as a threshold to determine whether a system is nitrogen-limited (ratios less than 16) or phosphorus-limited (ratios greater than 16), particularly when nutrient concentrations are low to moderate. The ratio of DIN to DIP (DIN:DIP, in moles of nitrogen per moles of phosphorus) within the context of these optimal ratios can be informative to understanding algal community dynamics and the effects of varying nitrogen and phosphorus additions to the lake. It should be noted that these concepts of nitrogen or phosphorus limitation are general in nature and could vary according to ecological diversity as well as the effect of external factors on the algae.

The seasonal pattern of $\mathrm{NO}_{3}$ in concert with undetectable $\mathrm{PO}_{4}$ led to a similar seasonal pattern in DIN:DIP ratios in

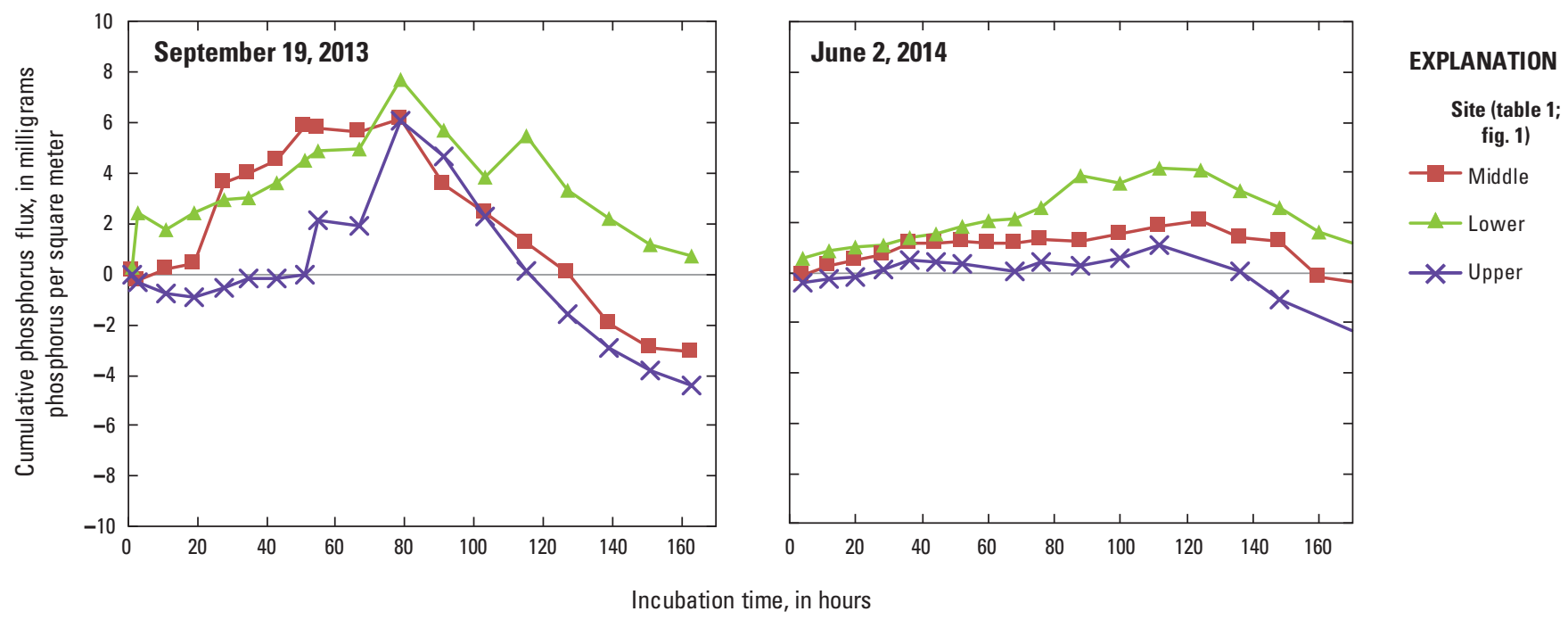

Figure 9. Cumulative flux of phosphate from anoxic sediment cores collected at three locations in Willow Creek Lake, Nebraska, September 19, 2013, and June 2, 2014. 


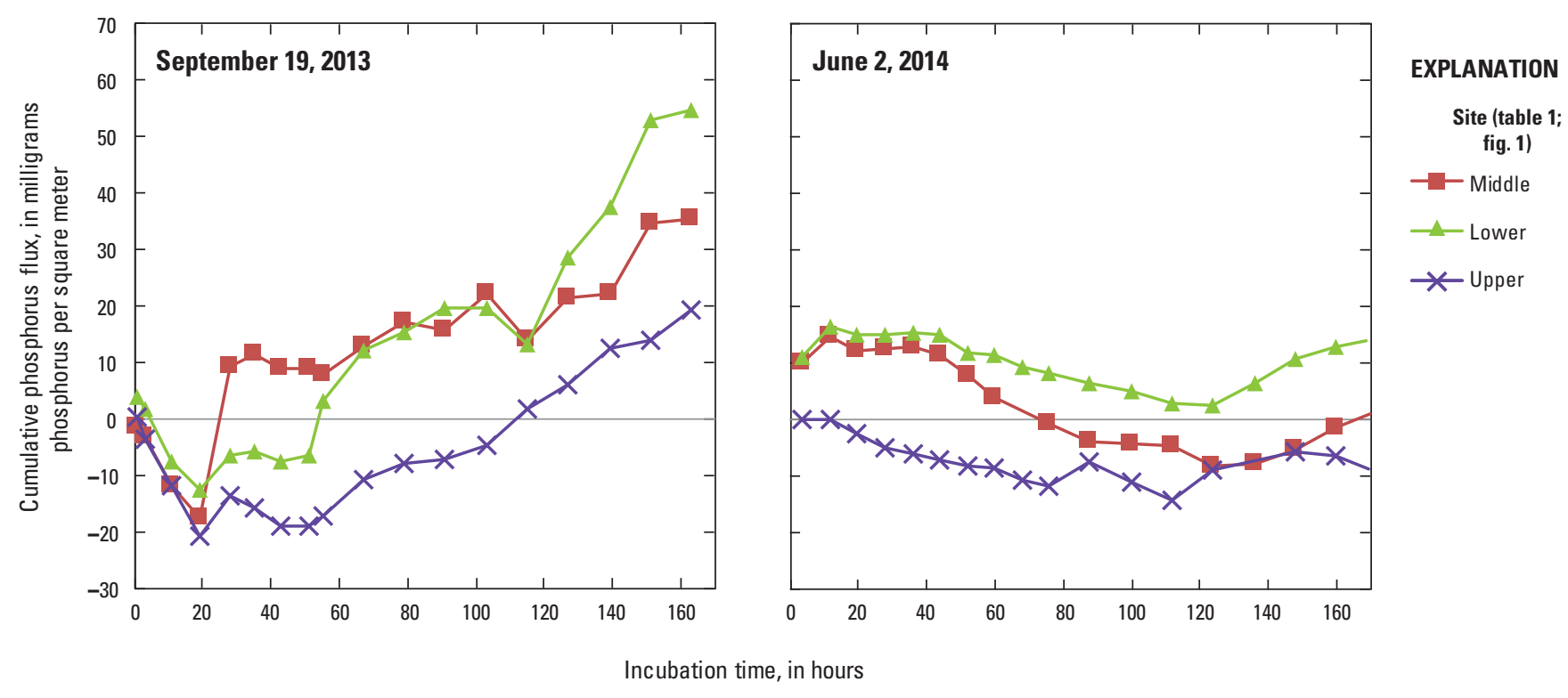

Figure 10. Cumulative flux of dissolved phosphorus from anoxic sediment cores collected at three locations in Willow Creek Lake, Nebraska, September 19, 2013, and June 2, 2014.

Willow Creek Lake. DIN:DIP ratios in the lake were computed for the monthly samples collected between May and September for 2012-14 using an arbitrary substitution for $\mathrm{PO}_{4}$ nondetections of one-half the detection level, or $0.005 \mathrm{mg} / \mathrm{L}$ (fig. 11). These ratios suggest that Willow Creek was phosphorus limited for much of the year in 2012 and 2013 but transitioned into a nitrogen-limited condition in August of each year, and possibly remained so until $\mathrm{NO}_{3}$ concentrations recovered during the winter. The 2014 samples did not have DIN:DIP ratios less than 496, suggesting that the lake was not nitrogen-limited in 2014.

\section{Physical Lake Characteristics}

Several physical characteristics of the lake water were measured and are summarized in table 9 and Hall and others (2018). Water temperature (fig. 12) and dissolved oxygen (table 9) had seasonal patterns - temperature rose throughout the spring, peaked during July and August, and fell in the late summer and fall. Daily average water temperatures generally first reached about $77^{\circ} \mathrm{F}$ in late June and maintained temperatures at least that warm through August each year. This provided at least 2 months of optimal temperatures for cyanobacteria to outcompete other algal types during the recreational-use season for the lake.

Turbidity values within the lake did not reflect drainage basin hydrology because most stream inflow (and, therefore, the sediment load) was observed during the spring months, and the daily average surface-level turbidities were largest during the summer months (July-September; fig. 12). This pattern suggests that the primary source of near-surface turbidity within Willow Creek Lake during the summer is the phytoplankton community, which is dominated by cyanobacteria (table 3).

\section{Climatic Characteristics}

Several meteorological variables were measured near the lake and are summarized in table 10 and Hall and others (2018). Air temperature was highest in 2012, especially during the winter and spring, and was lowest in 2014. The precipitation in 2012 was more than $10 \mathrm{in}$. lower than that of 2013 or 2014, which was accentuated by abnormally dry conditions from June through September. Mean wind speed showed a seasonal pattern by peaking during the early spring or winter and decreasing during the late summer (fig. 13).

\section{Relation of Nutrients and Other Factors to Cyanobacteria}

Cyanobacteria data were compared to nutrient loads and other factors that may be related to algal growth. Bivariate comparisons of phycocyanin (associated with the shallowest measurement depth, 1.6 feet) to the physicochemical factors indicated relations in some cases but also indicated that some of the measurements, like turbidity, might be responding to algal growth patterns rather than affecting them. Ultimately, a multivariate linear model was used to identify seasonality and cumulative $\mathrm{NO}_{3}$ loading as the factors that explained the most variance in cyanobacteria. Nitrogen and phosphorus contribute to cyanobacteria populations, and management strategies will benefit from quantification of nutrient loading characteristics among the monitored basins. Low amounts of internal nutrient 


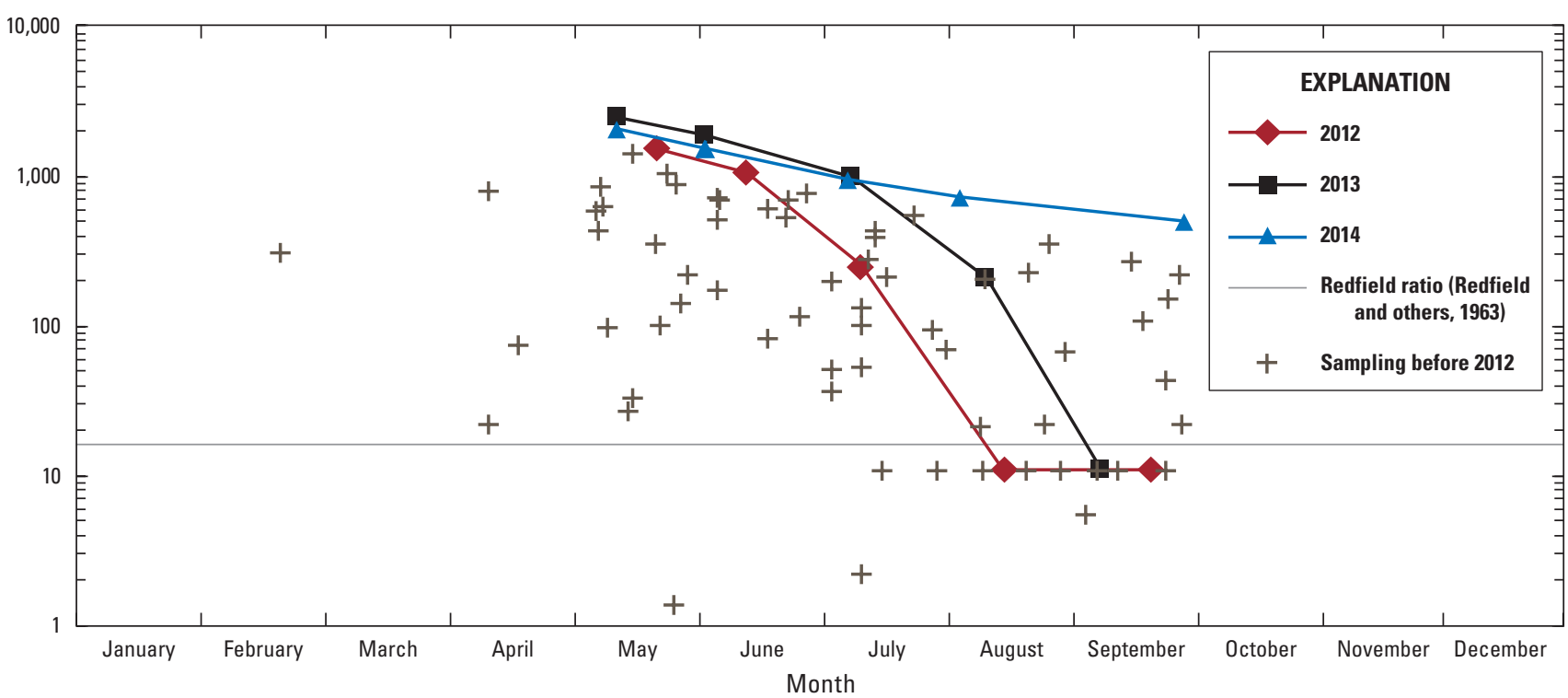

Figure 11. Seasonal pattern of the molar ratio of dissolved inorganic nitrogen to dissolved inorganic phosphorus in Willow Creek Lake, Nebraska, 2012-14. All sampling data are provided in Hall and others (2018).

Table 9. Monthly averages of shallow-water values for selected water-quality parameters, Willow Creek Lake, Nebraska, MaySeptember 2012-14.

\begin{tabular}{|c|c|c|c|c|c|c|}
\hline Year & Month & $\begin{array}{c}\text { Water } \\
\text { temperature, } \\
\text { in degrees Fahrenheit }\end{array}$ & $\begin{array}{c}\text { Specific conductance, } \\
\text { in microsiemens per } \\
\text { centimeter at } \\
25 \text { degrees Celsius }\end{array}$ & $\begin{array}{c}\mathrm{pH}, \\
\text { standard units }\end{array}$ & $\begin{array}{l}\text { Dissolved oxygen, } \\
\text { in milligrams per liter }\end{array}$ & $\begin{array}{c}\text { Turbidity, } \\
\text { in formazin } \\
\text { nephelometric units }\end{array}$ \\
\hline \multirow[t]{6}{*}{2012} & May & 66.8 & 339 & 8.9 & 9.50 & 12 \\
\hline & June & 73.9 & 317 & 9.0 & 9.09 & 20 \\
\hline & July & 83.1 & 250 & 9.6 & 9.55 & 27 \\
\hline & August & 76.3 & 263 & 9.1 & 8.39 & 23 \\
\hline & September & 67.0 & 291 & 9.3 & 9.93 & 24 \\
\hline & October & 50.8 & 329 & 8.7 & 10.5 & 25 \\
\hline \multirow[t]{6}{*}{2013} & May & 59.8 & 323 & 9.0 & 10.4 & 11 \\
\hline & June & 70.2 & 326 & 8.9 & 9.18 & 9.8 \\
\hline & July & 79.2 & 271 & 9.2 & 8.58 & 48 \\
\hline & August & 76.7 & 266 & 9.1 & 8.78 & 57 \\
\hline & September & 72.3 & 251 & 9.3 & 8.98 & 71 \\
\hline & October & 53.3 & 261 & 8.9 & 10.3 & 43 \\
\hline \multirow[t]{6}{*}{2014} & May & 61.5 & 335 & 8.7 & 10.5 & 11 \\
\hline & June & 73.8 & 316 & 8.6 & 9.30 & 27 \\
\hline & July & 76.2 & 307 & 8.7 & 8.62 & 37 \\
\hline & August & 76.7 & 301 & 8.5 & 7.36 & 33 \\
\hline & September & 68.4 & 299 & 8.5 & 8.36 & 39 \\
\hline & October & 57.5 & 317 & 8.4 & 9.06 & 14 \\
\hline
\end{tabular}



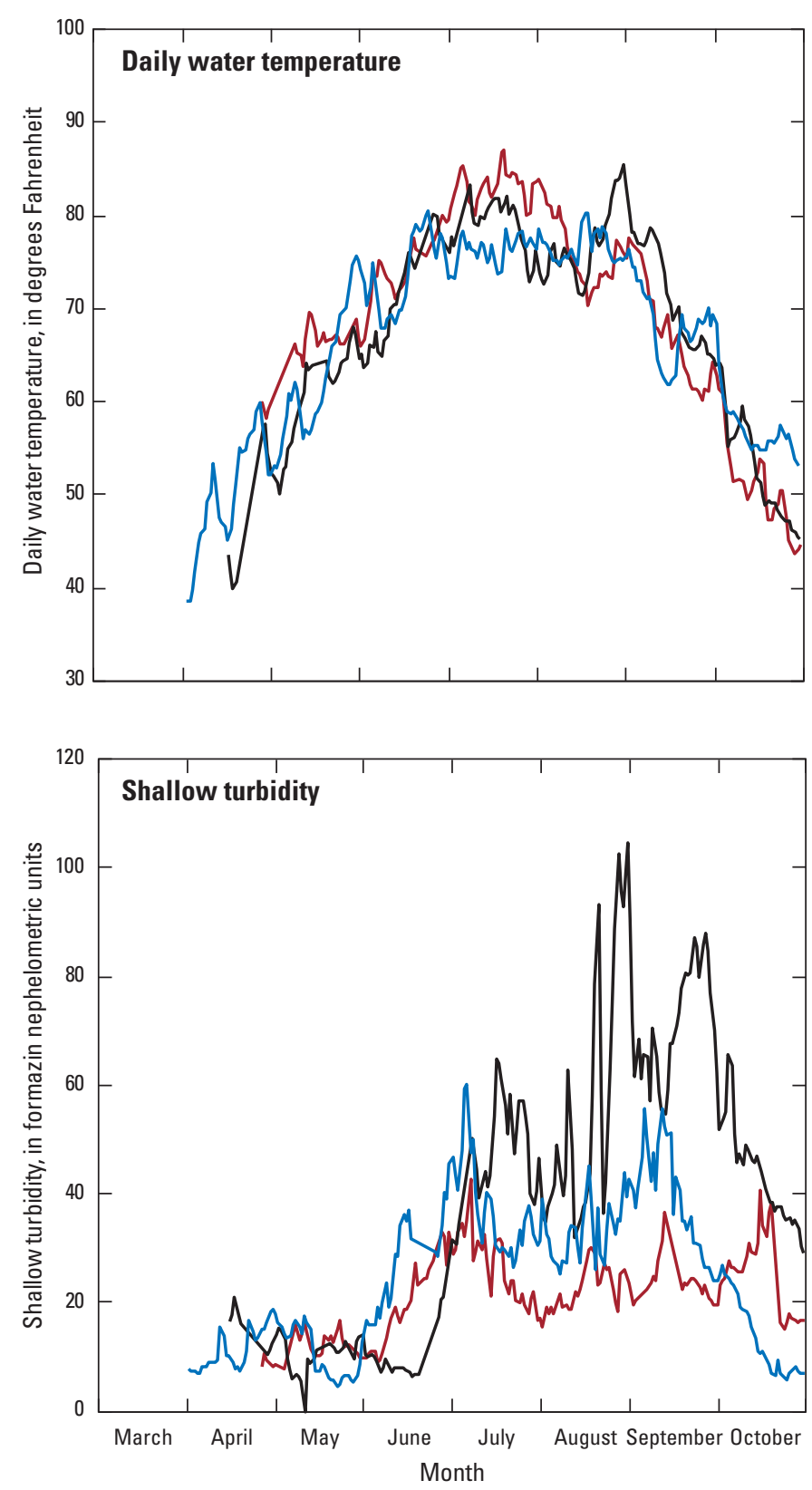

EXPLANATION

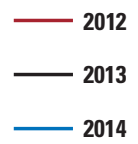

Figure 12. Time series of daily mean turbidity and water temperature near the water surface of Willow Creek Lake, Nebraska, 2012-14. loading observed during this study suggest that the lakebed sediment may play a negligible role in cyanobacteria population dynamics; therefore, comparisons to cyanobacteria in Willow Creek Lake were limited to external nutrient loads.

\section{Individual Comparisons}

A series of bivariate plots between phycocyanin and other measured constituents were made using biweekly averages of each to assess the strength of each relation (fig. 14). Biweekly values were used because they tended to dampen daily data variability while still retaining temporal patterns.

\section{Selection of Phycocyanin Density as Primary Biotic Response}

In nearly every case, the perceived relation of phycocyanin to the array of physicochemical factors seemed stronger than the relation of microcystin to those same factors (figs. $14 B-14 K$ ). This may be related to disassociation between cyanobacteria and microcystin at the swimming beach as compared to that in the main lake where the phycocyanin data were collected. For this study, phycocyanin results were used as the primary response variable.

\section{Relation of Phycocyanin Densities to Cumulative External Nutrient Loads}

Phycocyanin had an inverse relation to biweekly nutrient loads (figs. $14 B$ and $14 C$ ) and a positive relation with external, cumulative nutrient loads (summing the three stream sites and groundwater load contributions; figs. $14 D$ and $14 E$ ). This was likely because most of the annual lake loading was in the spring (figs. $8 C$ and $8 D$ ) when cyanobacteria populations are typically small and cyanobacteria expansion tends to happen in late summer. Cumulative loads may be a better predictor of phycocyanin density because the pool of nutrients that accumulate in the lake in a given year has a greater effect on the algal community than does the 2 -week nutrient load. Though figure 14 focuses on the inorganic forms of $\mathrm{NO}_{3}$ and $\mathrm{PO}_{4}$, similar patterns of cyanobacteria response to nutrient loading were observed for total nitrogen and TP. Phycocyanin was more strongly correlated to cumulative $\mathrm{NO}_{3}$ loads (fig. $14 D$ ) than cumulative $\mathrm{PO}_{4}$ loads (fig. $14 E$ ). Some of the variability in the relation of phycocyanin to $\mathrm{PO}_{4}$ loads may be explained by interannual differences and may indicate greater cyanobacteria dependence on lake nitrogen.

\section{Seasonal Phycocyanin Densities}

Cyanobacteria densities exhibited a seasonal pattern throughout the study and, as such, phycocyanin was negatively related to a seasonal component (computed as a sine transformation of the Julian day of each year). The tendency for 
Table 10. Monthly meteorological values near Willow Creek Lake, Nebraska, 2012-14.

$[--$, not applicable $]$

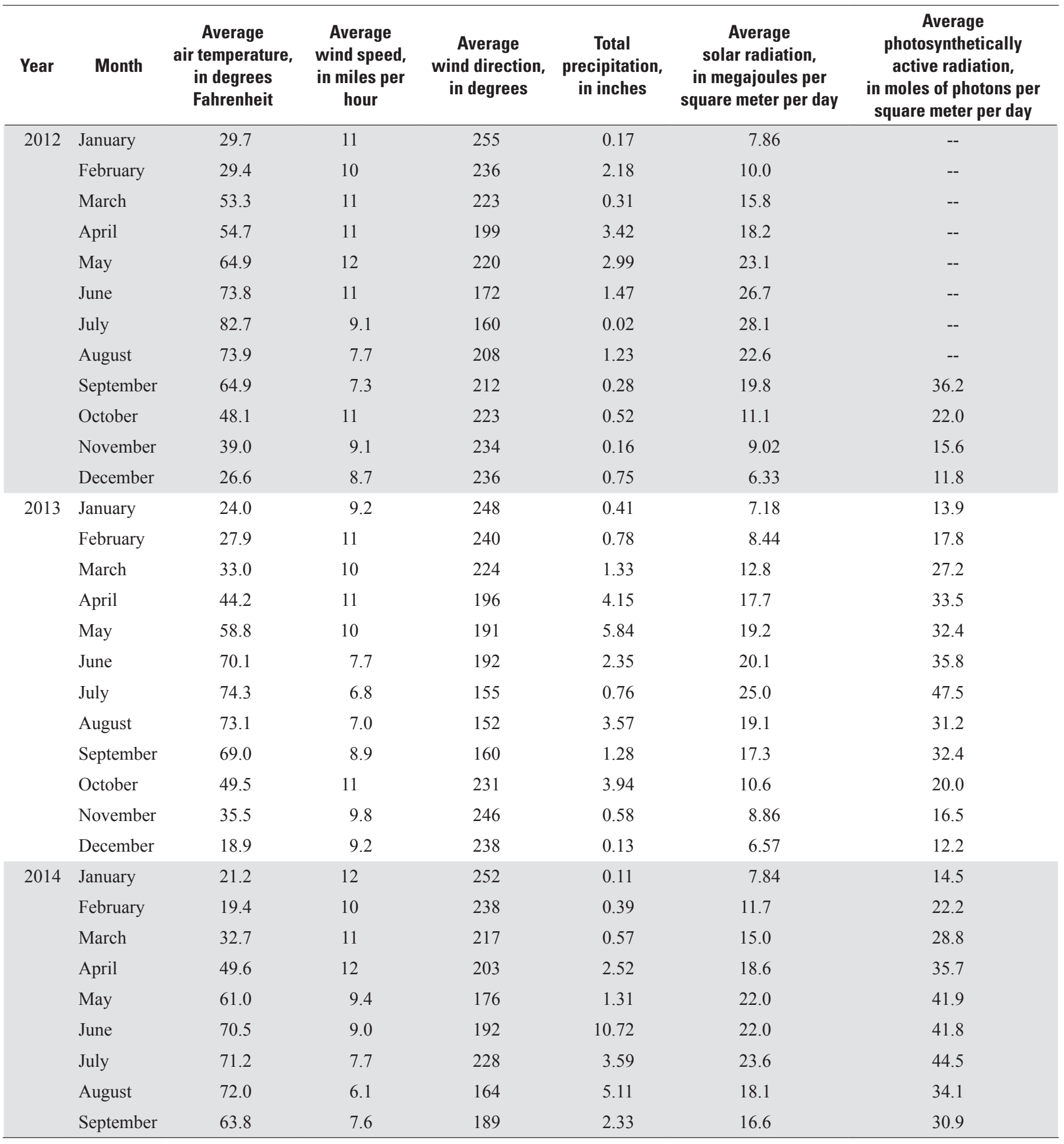




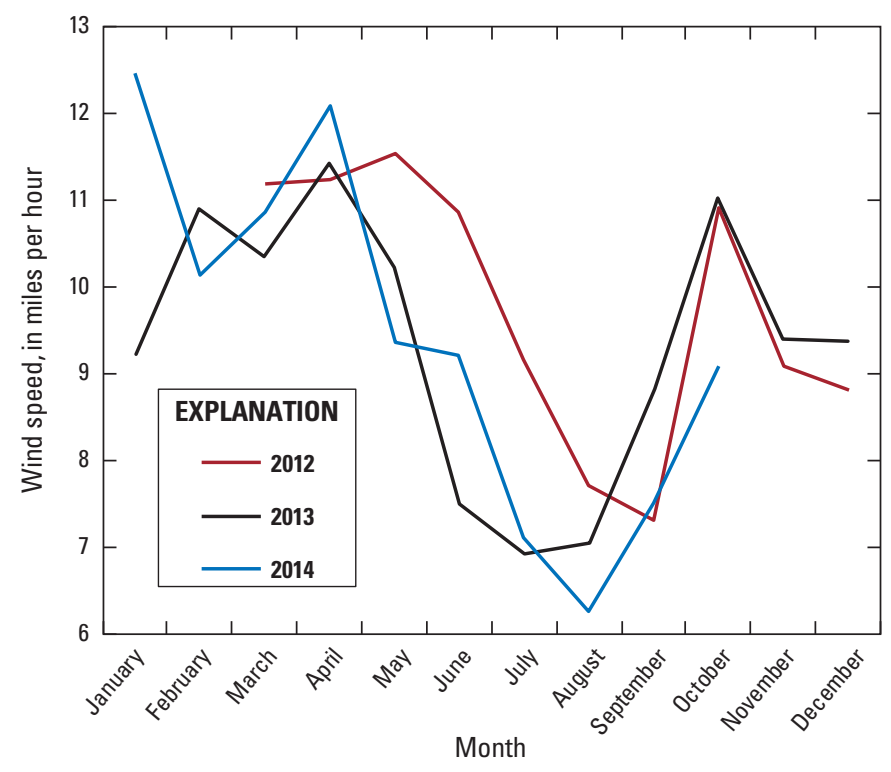

Figure 13 Mean monthly wind speed at Willow Creek Lake, Nebraska, 2012-14.

cyanobacteria to bloom in late summer led to a negative correlation of phycocyanin to this seasonality metric (fig. 14F). The inclusion of a seasonality term was intended mainly to help describe the observed pattern of cyanobacteria blooms in Willow Creek Lake that was consistent with the prevailing concept of algal succession.

\section{Available Nutrients in the Lake}

The comparisons of phycocyanin density to external nutrient loading suggest that the annual cumulative $\mathrm{NO}_{3}$ pattern (fig. 14D) was more consistent than that for cumulative $\mathrm{PO}_{4}$ (fig. 14E). As mentioned earlier, the DIN:DIP ratio can provide insight into the limiting nutrient in a system, with values less than 16 often indicating a nitrogen-limited system and greater than 16 indicating a phosphorus-limited system. These lines of evidence may point to a greater dependence on nitrogen, and this was further explored with a comparison of phycocyanin density to the DIN:DIP ratios in the lake (fig. 14G). The comparison of DIN:DIP to phycocyanin density indicated a similar pattern as that of seasonality (fig. 14F), with high phycocyanin concentrations associated with low DIN:DIP ratios. However, this comparison may be misleading when taken out of context because DIN:DIP and phycocyanin values are likely dependent on multiple interacting factors, such as those between nutrient loading and algal uptake or between the many factors suspected to be affecting cyanobacteria populations.

\section{Phycocyanin Relation to Physical Lake Characteristics}

Phycocyanin density had a weak negative relation to specific conductance and dissolved oxygen and a weak positive relation to water temperature and turbidity (figs. $14 H-14 K$ ). The elevated heat tolerance of cyanobacteria relative to other algae suggests water temperature as a potentially strong factor in the prevalence of cyanobacteria in the lake at warmer temperatures. Although the comparison of phycocyanin to water temperature did indicate the highest phycocyanin values tended to happen at warmer water temperatures, this relation varied substantially (fig. 14H). In many lakes, anoxic conditions in and near the lakebed can portend $\mathrm{PO}_{4}$ release into the water column and cause a subsequent growth of algaealthough this did not seem to be common in Willow Creek Lake during this study. Nonetheless, comparisons between lake phycocyanin densities at the surface and dissolved oxygen concentrations near the lakebed indicated larger phycocyanin densities when lakebed dissolved oxygen concentrations were small with a weak negative correlation (fig. 14J). Specific conductance was weakly negatively correlated with phycocyanin densities (fig. 14I), though that relation included some variability and was not explicitly clear. Because of the uncertainty in the relation and its cause, specific conductance was not considered a dependable factor for explaining phycocyanin patterns. Phycocyanin density was positively correlated with turbidity (fig. $14 K$ ), likely because of increased algal biomass in the water column rather than as a cause of that increased biomass. Nonetheless, the decrease in light penetration may have allowed cyanobacteria a competitive advantage over other types of phytoplankton because of their ability to regulate their vertical position within the water column to more optimal conditions for their growth and proliferation.

\section{Multiple Comparisons}

As part of a complex ecosystem, it was anticipated that cyanobacteria populations would depend on multiple factors simultaneously, and multivariate regressions were done accordingly. These regressions were intended to identify those physicochemical factors that best explained the cyanobacteria responses during the study and are not intended to be used in a predictive manner. Several combinations of the individual factors mentioned previously were explored, but a manual method of identifying a final model, as opposed to an automated method such as a stepwise technique, was used to better incorporate the knowledge of the system and to better meet the objective of the study. Given its distribution across multiple orders of magnitude, the phycocyanin density was transformed using a base- 10 logarithm before doing the regressions. A base-10 logarithmic transformation also was applied to several nutrient-loading factors and the DIN:DIP ratios.

Potentially causative factors representing conditions in the lake (water temperature, specific conductance, turbidity, 

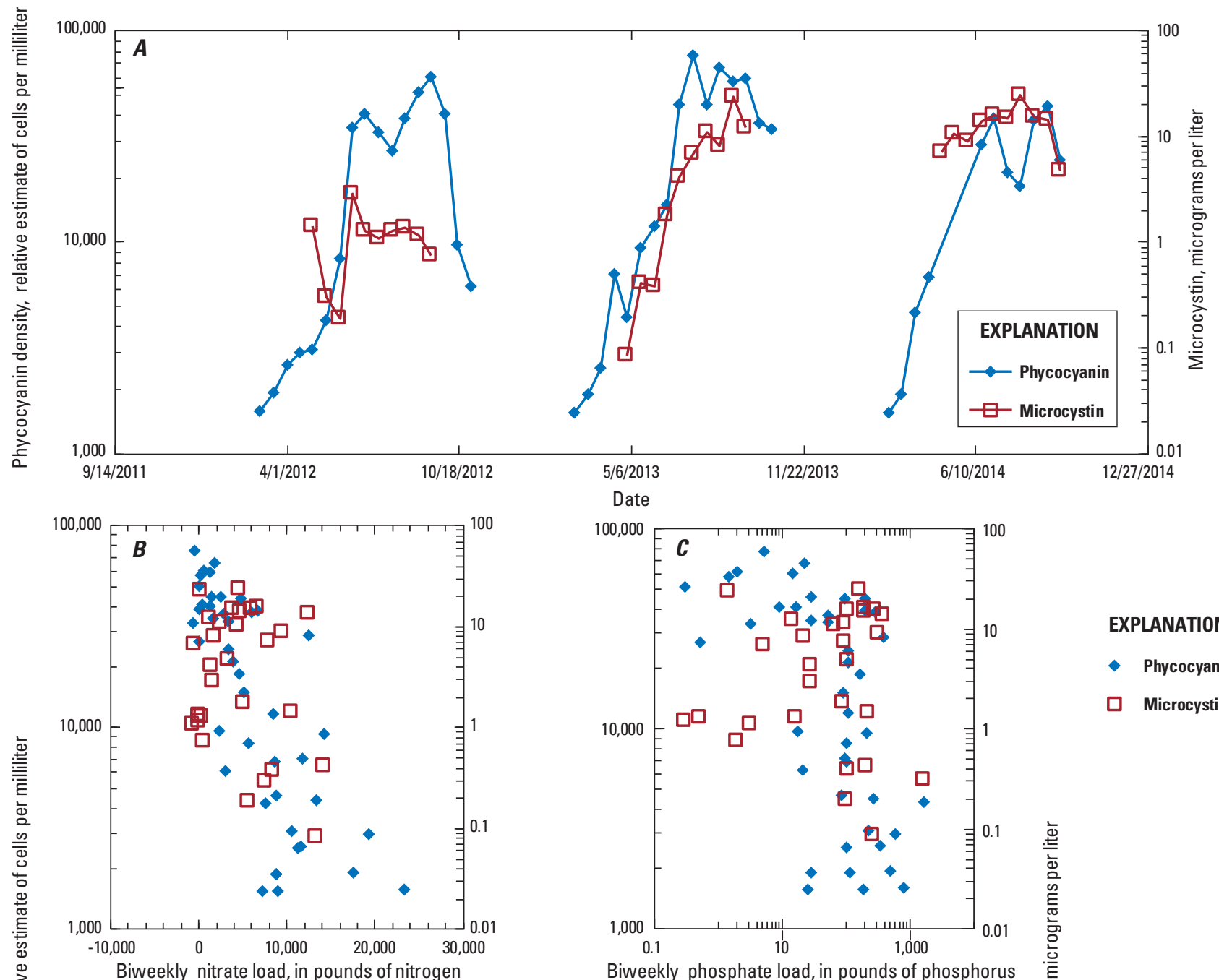

Biweekly phosphate load, in pounds of phosphorus
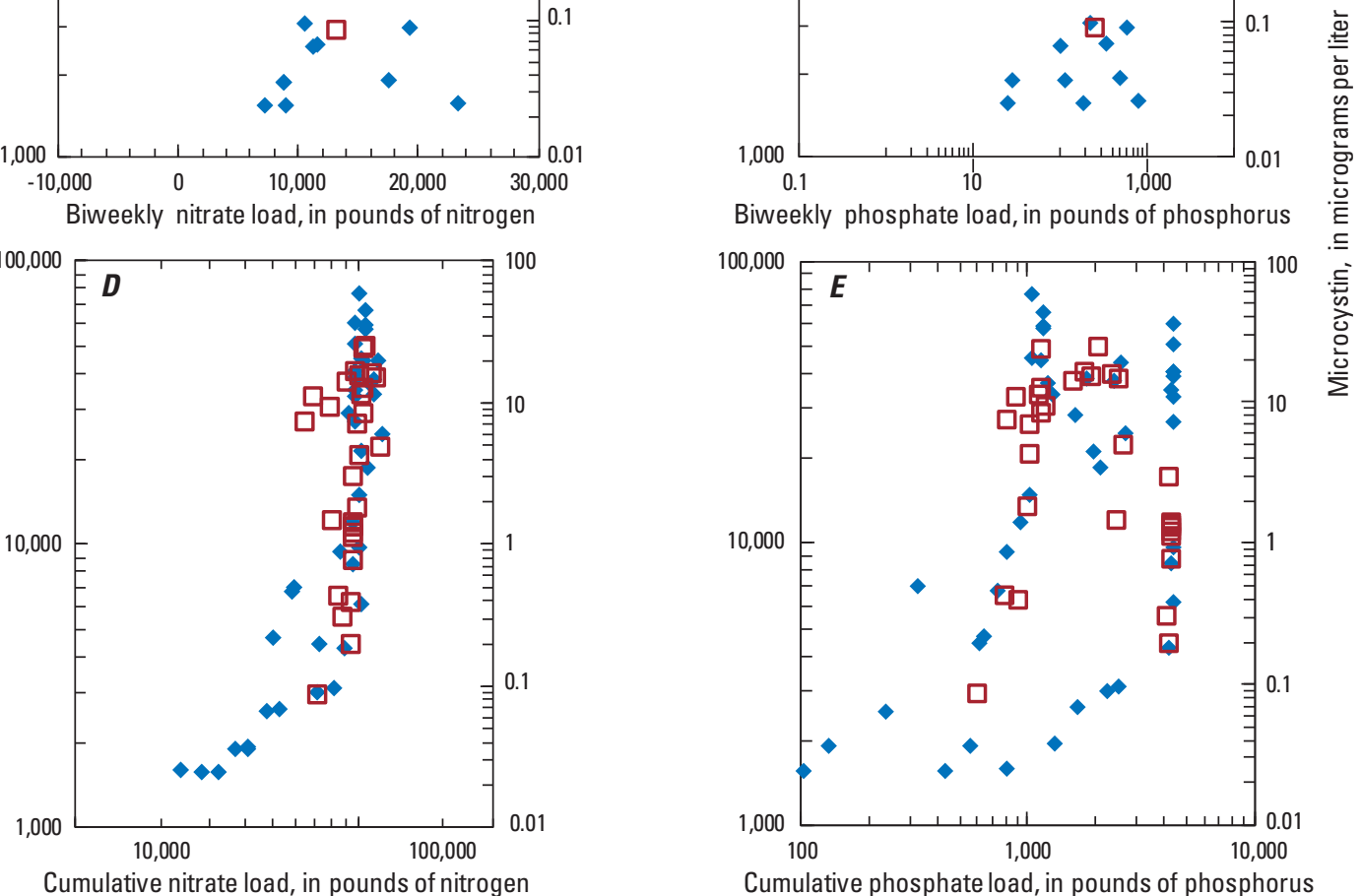

EXPLANATION

Phycocyanin

M Microcystin

Figure 14. Mean biweekly phycocyanin density and microcystin concentration compared to selected physicochemical factors measured at Willow Creek Lake, Nebraska, 2012-14. A, time series of phycocyanin density and microcystin concentration. Selected physicochemical factors: $B$, biweekly nitrate load. $C$, biweekly phosphate load. $D$, cumulative nitrate load. $E$, cumulative phosphate load. $F$, sine of the Julian day of the year. $G$, mean biweekly dissolved inorganic nitrogen to dissolved inorganic phosphorus ratio. $H$, mean biweekly water temperature. I, mean biweekly specific conductance. $J$, mean biweekly deep dissolved oxygen. $K$, mean biweekly turbidity. 

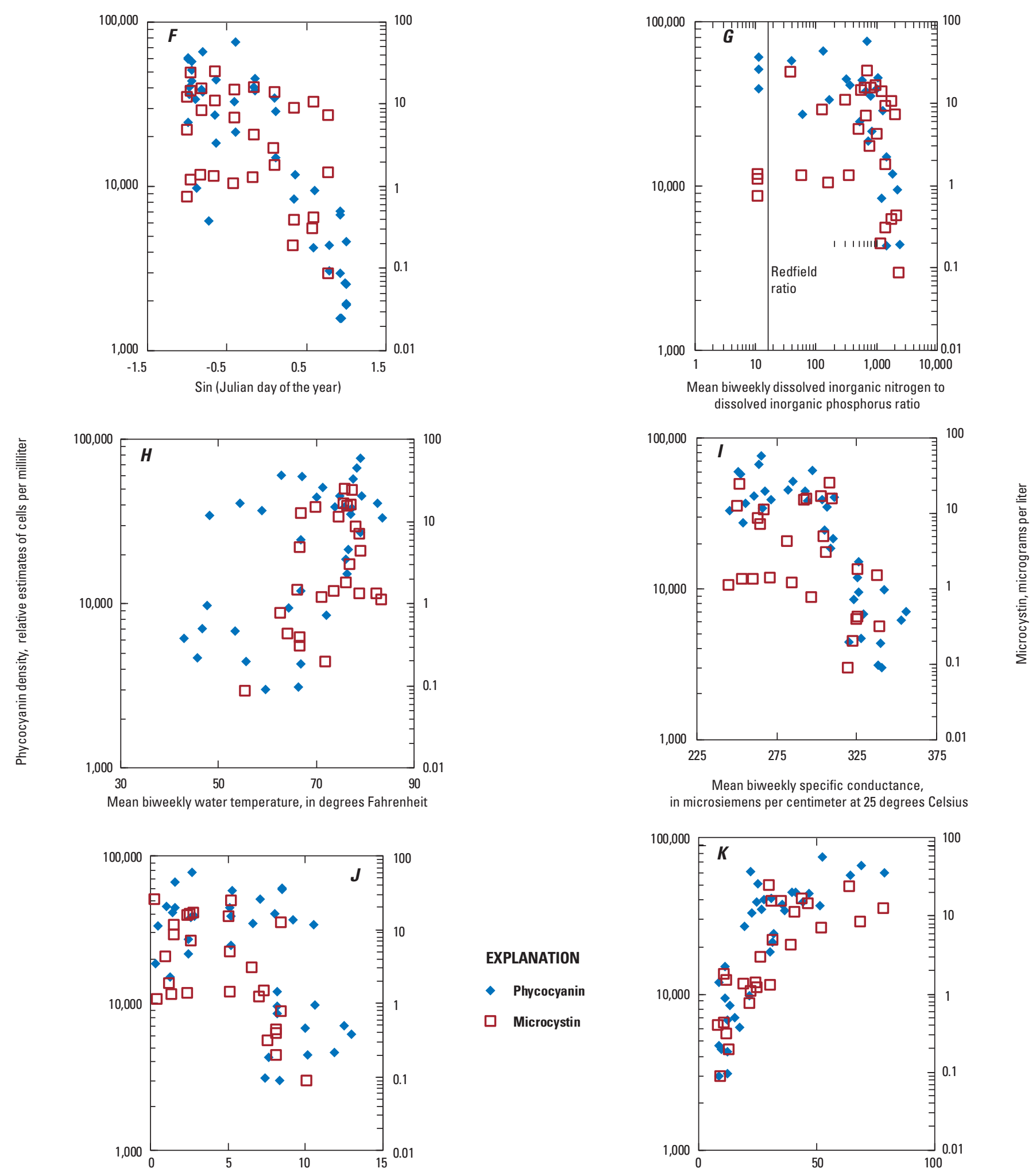

Mean biweekly deep dissolved oxygen, in milligrams per liter

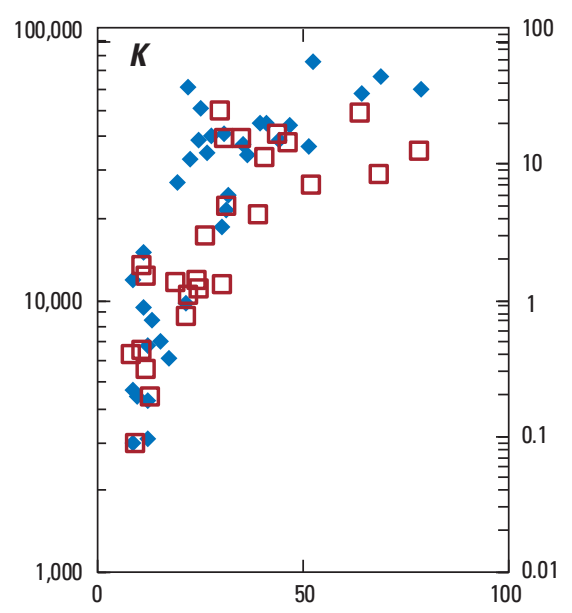

Mean biweekly turbidity, in formazin nephelometric units

Figure 14. Mean biweekly phycocyanin density and microcystin concentration compared to selected physicochemical factors measured at Willow Creek Lake, Nebraska, 2012-14. A, time series of phycocyanin density and microcystin concentration. Selected physicochemical factors: $B$, biweekly nitrate load. $C$, biweekly phosphate load. $D$, cumulative nitrate load. $E$, cumulative phosphate load. $F$, sine of the Julian day of the year. $G$, mean biweekly dissolved inorganic nitrogen to dissolved inorganic phosphorus ratio. $H$, mean biweekly water temperature. I, mean biweekly specific conductance. $J$, mean biweekly deep dissolved oxygen. $K$, mean biweekly turbidity.-Continued 
dissolved oxygen, and DIN:DIP) were explored cautiously because of the possibility that they were responding to the cyanobacteria populations rather than causing changes in those populations. For example, turbidity seemed to relate well to phycocyanin concentrations in the lake (fig. $14 K$ ), but this was likely a result of increased cyanobacteria growth leading to reduced water clarity. More complex was DIN:DIP, which was likely affected by past algal growth through the uptake and removal of nutrients but also could be considered a predictor of future algal growth, indicating the limiting concentrations of nutrients available. Although all were explored, ultimately water temperature was the only factor that was considered fully independent of the algal population.

A seasonality term was included in the exploration because of the observed progression of the algal community following a seasonal pattern (table 3 ) and because of the perceived relation between phycocyanin density and season (fig. 14F). Because of its dependence on air temperatures, the water temperature term was assumed to be seasonal, and the use of these terms in the same equation would be inappropriate.

Nutrient loading was included in the multivariate regressions because of the recognized association of cyanobacteria with eutrophic conditions as well as the observed relations of cumulative external nutrient loads to phycocyanin densities in the lake (figs. $14 D-14 E$ ). Though internal nutrient loading is often associated with elevated cyanobacteria in other lakes, its role in Willow Creek Lake was negligible based on analyses described earlier (figs. 9 and 10). Therefore, only the cumulative external nutrient loading was explored in the multivariate regressions. The cumulative $\mathrm{PO}_{4}$ load was often an insignificant term in the fitted regression model and typically had a negative coefficient, suggesting a negative relation to phycocyanin when including the effects of other factors. This contrasts with other areas, such as Lake Erie, that have seen a positive relation of cyanobacteria to tributary $\mathrm{PO}_{4}$ loads (Kane and others, 2014). Because of this, cumulative $\mathrm{PO}_{4}$ load was not included in the final regression; however, it is important to note that this does not imply that $\mathrm{PO}_{4}$ loading is unimportant to cyanobacteria growth but rather that the effect of $\mathrm{PO}_{4}$ loading may be masked by other, interrelated factors that are all affecting cyanobacteria growth in Willow Creek Lake. In fact, nitrogen has been hypothesized to have a more important role in the development of algal communities than might be expected in systems that are traditionally categorized to be phosphorus-limited (Lewis and Wurtsbaugh, 2008; Steffen and others, 2014).

The multivariate regression process identified seasonality and cumulative $\mathrm{NO}_{3}$ loading as the primary factors that explained variability in phycocyanin. Scrutiny of those regressions indicated three outliers that were having an undue effect on the regression results and that were potentially violating the assumptions of the regression approach. The subsequent omission of those outliers (associated with the biweekly periods starting October 16, 2012, November 1, 2012, and July 16, 2013) did not strongly affect the relation of phycocyanin to seasonality or $\mathrm{NO}_{3}$ loading but allowed the equation to satisfy the regression assumptions. The final multivariate regression equation predicted phycocyanin load $(P H Y)$ as a function of seasonality and cumulative $\mathrm{NO}_{3}$ load $\left(\Sigma N O_{3}\right)$ :

$$
\begin{gathered}
\log 10(\text { PHY })=-0.43 \sin (\text { JulianDay }) \\
+1.13 \log 10\left(\mathrm{NOO}_{3}\right)+2.34
\end{gathered}
$$

The fitted phycocyanin estimates produced a standard error of 0.19 logarithms of phycocyanin, a $R^{2}$ of 0.88 , and a NSE of 0.69 when compared to the observed phycocyanin responses at a biweekly frequency in the lake. For context, similar regressions of cyanobacteria response metrics to tributary nutrient loads in Lake Erie resulted in $R^{2}$ values ranging from 0.56 to 0.80 (Kane and others, 2014). Though the general trend of phycocyanin in a given year was represented in the final multivariate regression equation, the within-season variability was not well duplicated by the regression. The negative relation to seasonality was expected given the maxima of the seasonal term in the spring and the minima in the fall as well as the bivariate relation of seasonality to phycocyanin density (fig. 14F). The positive relation to cumulative $\mathrm{NO}_{3}$ loading suggests that the amount of nitrogen that entered the lake annually between 2012 and 2014 affected cyanobacteria concentrations.

\section{Implications for Cyanobacteria in Willow Creek Lake}

Correlation between cumulative nutrient loading and phycocyanin densities in the lake reveals potential implications for cyanobacteria population control. Although there was a significant positive correlation between phycocyanin density and cumulative $\mathrm{NO}_{3}$ loading (fig. 14D), cumulative $\mathrm{PO}_{4}$ loads also were weakly positively correlated to phycocyanin density (fig. 14E). The correlation of cyanobacteria to nitrogen and phosphorus loading to Willow Creek Lake may warrant the consideration of both nutrients in the landscape when trying to minimize cyanobacteria (Conley and others, 2009). Phycocyanin's significant correlation with a seasonal component may encompass some physicochemical parameters related to elevated cyanobacteria that are more difficult to modify through lake management, such as water temperature fluctuation and the seasonal progression of the algal community in the lake.

The predominance of external nutrient loading over internal loading is an important characteristic of Willow Creek Lake that makes it similar to other lakes in the region (Song and others, 2017). It suggests that management activities designed to remove nutrients from the lakebed (such as dredging) or disrupt the cycling of nutrients between the lakebed and the water column (such as flocculation techniques) may not be effective for cyanobacteria control, because most of those nutrients are originating outside of the lakebed. 
Management activities that focus primarily on reducing lake nutrients entry may be more beneficial.

It is likely that expansion of the cyanobacteria community is associated with nitrogen and phosphorus species in general rather than nitrogen or phosphorus alone. Most ( 95 percent) of the surface $\mathrm{NO}_{3}$ load enters the lake from the $133-\mathrm{mi}^{2}$ subbasin associated with Willow Creek at the Foster site (fig. 8A; table 7). In contrast, 43 percent of the TKN load, 27 percent of the inorganic phosphorus load, and more than one-half (57 percent) of the $\mathrm{PO}_{4}$ load originated from the $18-\mathrm{mi}^{2}$ subbasin associated with the NT site (figs. $8 A-8 B$; table 7). Nutrient load differences between the Foster and NT site subbasins may be a result of differences in basin-wide characteristics such as land use, physiography, or hydrology. As mentioned earlier in the "Differences in Streamflow Characteristics Between the Sites" section, the NT site subbasin was flashier than the rest of the basin, suggesting a greater proportion of overland runoff. The higher $K f$ coupled with greater overland runoff increases erosion potential (whether from upland erosion or channel erosion) in the NT site subbasin. This is further manifested by higher concentrations of TKN, TP, and $\mathrm{PO}_{4}$, all of which could be considered sedimentassociated constituents. As a result, substantial reductions in phosphorus and particulate-bound nitrogen loading to the lake would likely happen with a reduction in erosion in the NT site subbasin.

Compared with the other nutrient species, $\mathrm{NO}_{3}$ is more soluble and less likely to be associated with sediment particles. Therefore, larger loads and yields of $\mathrm{NO}_{3}$ in the Foster site subbasin indicate predominance of dissolved constituent transport that may happen through subsurface discharge to Willow Creek from groundwater or via artificial drainage systems. Relative to the NT site subbasin, infiltration plays a greater role in the hydrologic cycle of the Foster site subbasin that could result in a higher likelihood of subsurface discharge to Willow Creek than to the North Tributary. Although nutrient loads from the ST site were comparatively small, the yields were similar to the Foster site (table 7), with $\mathrm{NO}_{3}$ being the predominant nutrient exported from the basin. It is likely that the infiltration characteristics of the ST site subbasin are more similar to the Foster site subbasin than the NT site subbasin. This difference in hydrologic characteristics supports the idea of subsurface pathways playing a larger role in $\mathrm{NO}_{3}$ loading from Willow Creek and the South Tributary than the North Tributary.

\section{Summary}

Cyanobacteria (also referred to as blue-green algae) are a natural part of lake phytoplankton assemblages that are favored by eutrophic (nutrient rich and highly productive) conditions and can outcompete other phytoplankton types. Cyanobacteria are detrimental to lakes because some strains produce cyanotoxins. Cyanotoxins have been responsible for human or animal deaths in at least 27 States, including Nebraska. As of 2018, microcystins are believed to be the most common group of more than 80 known variants of cyanotoxins.

This report compiles data from the Willow Creek Basin and Willow Creek Lake, including intensive data collection between 2012 and 2014, and relate cyanobacteria and physicochemical water-quality properties, including external nutrient loading. To better understand factors affecting cyanobacteria concentrations in Willow Creek Lake, the U.S. Geological Survey, in cooperation with the Lower Elkhorn Natural Resources District, the Nebraska Department of Environmental Quality, the University of Nebraska-Lincoln, the Nebraska Department of Natural Resources, the Nebraska Game and Parks Commission, and the Nebraska Environmental Trust, completed a collaborative study of Willow Creek drainage basin and Willow Creek Lake between 2012 and 2014. The objectives of this study were to quantify and characterize cyanobacteria densities in Willow Creek Lake, characterize potential causes of cyanobacteria blooms within the Willow Creek Basin, identify relations between cyanobacteria in Willow Creek Lake and potential causes, and provide information to use as guidance for managing cyanobacteria in Willow Creek Lake.

Lake cyanobacteria densities were assessed from weekly sampling of microcystin, periodic sampling of algal taxonomy, and hourly measurements of an algal pigment unique to cyanobacteria, phycocyanin. Microcystin data seemed to be nonrepresentative of overall lake conditions (likely as a result of wind conditions), and cyanobacteria taxonomy sample frequency was not extensive enough to represent the study period. As a result, phycocyanin data were used for comparisons to potential water-quality and environmental factors in this report. Phycocyanin data indicated seasonal rises in cyanobacteria during all 3 years of the study and had middle to late summer maxima. Willow Creek Lake correlative data included estimated external and internal nutrient loads, lake physical characteristics, and local meteorological conditions. Nutrient loads (nitrogen as nitrate plus nitrite $\left[\mathrm{NO}_{3}\right]$, total Kjeldahl nitrogen [TKN], total phosphorus [TP], and phosphorus as phosphate $\left[\mathrm{PO}_{4}\right]$ ) supplied to Willow Creek Lake from surface water and groundwater were calculated for March 2012 through October 2014. External nutrient loads were calculated as the product of streamflow (or groundwater flow) and nutrient concentration.

Several meteorological variables were measured near the lake. Air temperature was higher during 2012, and total precipitation was more than 10 inches lower in 2012 than in 2013 or 2014. Mean wind speed had a seasonal pattern, with winds decreasing during the late summer and peaking during the winter.

A water balance approach was used to estimate flow volumes across multiple pathways to Willow Creek Lake, including streamflow, groundwater, precipitation, and evaporation. The water balance estimated a predominantly outward flow of groundwater from the lake. The major inflow component to the lake was from Willow Creek and the major outflow 
was into the groundwater system. Surface inflow components were characterized by spring runoff that transitioned into dry conditions in the summer for 2012 and 2013 but were more evenly distributed through 2014. Although surface outflows ceased by July 2012 and did not recover during the remainder of the study, it contributed a considerable part of the monthly water balance before flow ceased.

Nutrient concentrations were derived from sampling data collected or compiled for this study, including more than 200 stream samples, 12 groundwater samples, and 106 lake samples. Stream sampling began on June 29, 2012, by which time outflow from the lake had ceased, and did not resume for the remainder of the study period. Because of this, there were no outflow samples collected for nutrient analysis.

Nutrient loads were calculated for the three surfacewater monitoring sites using statistical relations to streamflow, seasonality, and temporal trends. Groundwater loads were calculated as the product of the daily groundwater flow volume (which was typically, but not always, away from the lake) and either the nutrient concentration of the lake (during periods of flow away from the lake) or the surrounding groundwater nutrient concentration in nearby wells (during periods of flow into the lake).

Surface flows contributed the most external nutrients to the lake, whereas the only nutrient export from the lake was during times of water losses to the groundwater system. Most $\mathrm{NO}_{3}$ load was from the main stem of Willow Creek. TKN, TP, and $\mathrm{PO}_{4}$ loads to the lake were more evenly split between Willow Creek and the smaller drainage of the North Tributary. As a result, substantial reductions in phosphorus and particulatebound nitrogen loading to the lake would likely happen with a reduction in erosion in the North Tributary subbasin. During the course of the study, the total nitrogen load to the lake was 226 tons. The total phosphorus load to the lake during the study was 8.42 tons, about one-half of which was in the form of $\mathrm{PO}_{4}$.

Internal loading of phosphorus from the lakebed was also evaluated in Willow Creek Lake to characterize nutrient release or uptake rates from lake sediment cores. Measured release rates were low relative to literature values and were much lower than rates measured in other lakes in southeastern Nebraska. These internal nutrient loads were negligible compared with external loads.

Several lake water physical characteristics were measured at multiple depths on an hourly basis between April and October of each year of the study, including water temperature, specific conductance, $\mathrm{pH}$, dissolved oxygen, and turbidity. Water temperature and dissolved oxygen exhibited seasonal patterns: temperature increased throughout the spring, peaked during July and August, and decreased again in the late summer and fall. Turbidity was not affected by spring runoff at the location in the lake where it was measured but had maxima during the late summer months (July-September). This pattern suggests that the primary source of turbidity within Willow Creek Lake during the summer may be the phytoplankton community and concomitant water temperatures help cyanobacteria accrue biomass, which increases turbidity at the lake site. Increased turbidity because of cyanobacteria likely decreased light penetration and likely allowed cyanobacteria competitive advantage over other types of phytoplankton because of their ability to regulate their vertical position within the water column to more optimal conditions for their growth and proliferation.

Phycocyanin densities and microcystin concentrations were compared to nutrient loads and other physicochemical factors that might be correlated with algal growth. Phycocyanin relations to environmental factors were stronger than microcystin relations. This may be because the microcystin concentrations at the sampling location do not always represent the rest of the lake. As a result, phycocyanin density measurements were used as a proxy for cyanobacteria for this study. Phycocyanin correlations with environmental factors not only indicated relations in some cases but also suggested that some measurements, such as turbidity and nutrient ratios, might be responding to algal growth patterns rather than the other way around. Comparisons to external nutrient loading suggest a more consistent pattern with $\mathrm{NO}_{3}$ than with $\mathrm{PO}_{4}$.

Ultimately, a multivariate regression that incorporated seasonality and cumulative nitrate loading was derived. Though the general trend of phycocyanin in a given year was represented, the within-season variability was not well duplicated by the regression. The positive relation to cumulative $\mathrm{NO}_{3}$ loading suggests that the amount of nitrogen that entered the lake annually between 2012 and 2014 had an effect on the cyanobacteria concentrations. Nitrogen and phosphorus loading are likely contributing to cyanobacteria growth in the lake, although differences in the nutrient loading characteristics were observed between the monitored tributaries.

\section{References Cited}

Allen, R.G., Pereira, L.S., Raes, D., and Smith, M., 1998, Crop evapotranspiration: Rome, Italy, United Nations Food and Agriculture Organization, FAO Irrigation and Drainage Paper no. 56, 300 p. [Also available at https://www. kimberly.uidaho.edu/water/fao56/fao56.pdf.]

Anderson, K.A., and Downing, J.A., 2006, Dry and wet atmospheric deposition of nitrogen, phosphorus and silicon in an agricultural region: Water, Air, and Soil Pollution, v. 176 , nos. $1-4$, p. 351-374 [Also available at https://doi. org/10.1007/s11270-006-9172-4.]

Baker, D.B., Richards, R.P., Loftus, T.T., and Kramer, J.W., 2004, A new flashiness index - Characteristics and applications to midwestern rivers and streams: Journal of the American Water Resources Association, v. 40, no. 2, p. 503-522, [Also available at https://doi.org/10.1111/j.1752-1688.2004. tb01046.x.] 
Beversdorf, L.J., Miller, T.R., and McMahon, K.D., 2013, The role of nitrogen fixation in cyanobacterial bloom toxicity in a temperate, eutrophic lake: PLoS ONE, v. 8, no. 2, p. e56103, [Also available at https://doi.org/10.1371/journal.pone.0056103.]

Boström, B., Andersen, J.M., Fleischer, S., and Jansson, M., 1988, Exchange of phosphorus across the sediment-water interface: Hydrobiologia, v. 170, no. 1, p. 229-244, [Also available at https://doi.org/10.1007/BF00024907.]

Bozarth, C.S., Schwartz, A.D., Shepardson, J.W., Colwell, F.S., and Dreher, T.W., 2010, Population turnover in a Microcystis bloom results in predominantly nontoxigenic variants late in the season: Applied and Environmental Microbiology, v. 76, no. 15, p. 5207-5213, [Also available at https://doi.org/10.1128/AEM.00001-10.]

Brakhage, P.A., 2009, Cyanobacteria, the Nebraska experience: Lakeline Magazine, v. 29, no. 4, p. 29-33.

Center for Advanced Land Management Information Technologies, 2017, Delineation of 2005 land use patterns for the State of Nebraska Department of Natural Resources: University of Nebraska School of Natural Resources, accessed October 5, 2017, at http://snr.unl.edu/data/download/geographygis/2005_Nebraska_landuse_map.pdf.

Chang, C.C.Y., Langston, J., Riggs, M., Campbell, D.H., Silva, S.R., and Kendall, C., 1999, A method for nitrate collection for $\delta^{15} \mathrm{~N}$ and $\delta^{18} \mathrm{O}$ analysis from waters with low nitrate concentrations: Canadian Journal of Fisheries and Aquatic Sciences, v. 56, no. 10, p. 1856-1864, [Also available at https://doi.org/10.1139/f99-126.]

Chorus, I., and Bartram, J., eds., 1999, Toxic cyanobacteria in water-A guide to their public health consequences, monitoring and management: London, E \& FN Spon, World Health Organization, 416 p. [Also available at http://www. who.int/water_sanitation_health/resourcesquality/toxcyanbegin.pdf.]

Conley, D.J., Paerl, H.W., Howarth, R.W., Boesch, D.F., Seitzinger, S.P., Havens, K.E., Lancelot, C., and Likens, G.E., 2009, Controlling eutrophication-Nitrogen and phosphorus: Science, v. 323, no. 5917, p. 1014-1015, [Also available at https://doi.org/10.1126/science.1167755.]

Cooke, G.D., Welch, E.B., Peterson, S.A., and Nichols, S.A, 2005, Restoration and management of lakes and reservoirs (3d ed.): CRC Press, 616 p.

Dodds, W.K., and Whiles, M.R., 2010, Freshwater ecologyConcepts and environmental applications of limnology ( $2 \mathrm{~d}$ ed.): Burlington, Mass., Academic Press, 829 p.

Edmondson, W.T., 1970, Phosphorus, nitrogen and algae in Lake Washington after diversion of sewage: Science, v. 169, no. 3946 , p. $690-691$.
Exner, M.E., Spalding, R.F., and Harrell, D.M., 2005, Development of a quality-assessed agrichemical database for monitoring anthropogenic impacts on ground-water quality: Environmental Monitoring and Assessment, v. 107, nos. 1-3, p. 249-257, [Also available at https://doi. org/10.1007/s10661-005-3108-0.]

Fausey, N.R., Brown, L.C., Belcher, H.W., and Kanwar, R.S., 1995, Drainage and water quality in Great Lakes and cornbelt States: Journal of Irrigation and Drainage Engineering, v. 121, no. 4, p. 283-288, [Also available at https://doi. org/10.1061/(ASCE)0733-9437(1995)121:4(283).]

Gill, M.A., 1979, Sedimentation and useful life of reservoirs: Journal of Hydrology, v. 44, nos. 1-2, p. 89-95, [Also available at https://doi.org/10.1016/0022-1694(79)90148-3.]

Gormly, J.R., and Spalding, R.F., 1979, Sources and concentrations of nitrate-nitrogen in ground water of the Central Platte Region, Nebraska: Groundwater, v. 17, no. 3, p. 291-301, [Also available at https://doi. org/10.1111/j.1745-6584.1979.tb03323.x.]

Graham, J.L., Jones, J.R., Jones, S.B., Downing, J.A., and Clevenger, T.E., 2004, Environmental factors influencing microcystin distribution and concentration in the Midwestern United States: Water Research, v. 38, no. 20, p. 4395-4404. [Also available at https://doi.org/10.1016/j. watres.2004.08.004.]

Graham, J.L., Loftin, K.A., Ziegler, A.C., and Meyer, M.T., 2008, Guidelines for design and sampling for cyanobacterial toxin and taste-and-odor studies in lakes and reservoirs: U.S. Geological Survey Scientific Investigations Report 2008-5038, 39 p. [Also available at https://pubs.usgs.gov/ sir/2008/5038/.]

Hall, B.M., Rus, D.L., and Thomas, S.A., 2018, Monitoring data for Willow Creek Lake, Nebraska, 2012-14: U.S. Geological Survey data release, https://doi.org/10.5066/P9RBDQI5.

Hambrook Berkman, J.A., and Canova, M.G., 2007, Algal biomass indicators (ver. 1.0): U.S. Geological Survey Techniques of Water-Resources Investigations, book 9, chap. A7, sec. 7.4. [Also available at http://pubs.water.usgs. gov/twri9A7.]

Healy, R.W., Winter, T.C., LaBaugh, J.W., and Franke, O.L., 2007, Water budgets-Foundations for effective waterresources and environmental management: U.S. Geological Survey Circular 1308, 90 p. [Also available at https://pubs. usgs.gov/circ/2007/1308/.] 
Heisler, J., Glibert, P.M., Burkholder, J.M., Anderson, D.M., Cochlan, W., Dennison, W.C., Dortch, Q., Gobler, C.J., Heil, C.A., Humphries, E., Lewitus, A., Magnien, R., Marshall, H.G., Sellner, K., Stockwell, D.A., Stoecker, D.K., and Suddleson, M., 2008, Eutrophication and harmful algal blooms-A scientific consensus: Harmful Algae, v. 8, no. 1, p. 3-13. [Also available at https://doi.org/10.1016/j. hal.2008.08.006.]

Helsel, D.R., and Hirsch, R.M., 2002, Statistical methods in water resources: U.S. Geological Survey Techniques of Water Resources Investigations, book 4, chap. A3, 522 p. [Also available at https://pubs.usgs.gov/twri/twri4a3/.]

Hillebrand, H., Dürselen, C., Kirschtel, D., Pollingher, U., and Zohary, T., 1999, Biovolume calculation for pelagic and benthic microalgae: Journal of Phycology, v. 35, no. 2, p. 403-424, [Also available at https://doi.org/10.1046/ j.1529-8817.1999.3520403.x.]

Kane, D.D., Conroy, J.D., Richards, R.P., Baker, D.B., and Culver, D.A., 2014, Re-eutrophication of Lake Erie-Correlations between tributary nutrient loads and phytoplankton biomass: Journal of Great Lakes Research, v. 40, no. 3, p. 496-501, [Also available at https://doi.org/10.1016/j. jglr.2014.04.004.]

Kennedy, E.J., 1983, Computation of continuous records of streamflow: U.S. Geological Survey Techniques of WaterResources Investigations, book 3, chap. A13, 52 p. [Also available at https://pubs.usgs.gov/twri/twri3-a13/.]

Kilpatrick, F.A., and Schneider, V.R., 1983, Use of flumes in measuring discharge: U.S. Geological Survey Techniques of Water-Resources Investigations, book 3, chap. A14, 46 p. [Also available at https://pubs.usgs.gov/twri/twri3-a14/.]

Lewis, W.M., Jr., and Wurtsbaugh, W.A., 2008, Control of lacustrine phytoplankton by nutrients-Erosion of the phosphorus paradigm: International Review of Hydrobiology, v. 93, nos. 4-5, p. 446-465, [Also available at https://doi. org/10.1002/iroh.200811065.]

McLaughlin, K., Silva, S., Kendall, C., Stuart-Williams, H., and Paytan, A., 2004, A precise method for the analysis of $\delta^{18} \mathrm{O}$ of dissolved inorganic phosphate in seawater: Limnology and Oceanography, Methods, v. 2, no. 7, p. 202-212, [Also available at https://doi.org/10.4319/lom.2004.2.202.]

Metcalf, J.S., and Codd, G.A., 2003, Analysis of cyanobacterial toxins by immunological methods: Chemical Research in Toxicology, v. 16, no. 2, p. 103-111, [Also available at https://doi.org/10.1021/tx0200562.]

Mueller, D.K., Schertz, T.L., Martin, J.D., and Sandstrom, M.W., 2015, Design, analysis, and interpretation of field quality-control data for water-sampling projects: U.S. Geological Survey Techniques and Methods, book 4, chap. C4, 54 p. [Also available at https://doi.org/10.3133/tm4C4.]
Nash, J.E., and Sutcliffe, J.V., 1970, River flow forecasting through conceptual models part I-A discussion of principles: Journal of Hydrology, v. 10, no. 3, p. 282-290, [Also available at https://doi.org/10.1016/0022-1694(70)90255-6.]

National Atmospheric Deposition Program, 2016, National trends network: Champaign, Ill., U.S. Department of Agriculture, digital data, accessed June 14, 2016, at http://nadp. sws.uiuc.edu/ntn/.

National Climatic Data Center, 2015, Climate data online: Asheville, N.C., National Oceanic and Atmospheric Administration, digital data, accessed November 2015 at https:// www.ncdc.noaa.gov/cdo-web/.

National Weather Service, variously dated, Norfolk, NE, annual climate report: Silver Spring, Md., National Weather Service, digital data, accessed January and December 2014 at http://w2.weather.gov/climate/index.php?wfo=oax.

Natural Resources Conservation Service, 2011, Soil survey geographic database: Fort Worth, Tex., U.S. Department of Agriculture, digital data, accessed April 10, 2012, at http:// sdmdataaccess.nrcs.usda.gov/.

Nebraska Department of Environmental Quality, 2015, 2014 Nebraska Water Monitoring Programs Report: Lincoln, Nebr., Nebraska Department of Environmental Quality, 57 p., accessed July 2015 at http://deq.ne.gov/NDEQProg.nsf/.

Nebraska Department of Natural Resources, 2018, Active NeDNR and USGS stream gages/links to gage data: Nebraska Department of Natural Resources, digital data, accessed September 2018 at https://nednr.nebraska.gov/ RealTime/Gage/Index.

Nickel Engineering, 2012, Willow Creek dam groundwater study: Lincoln, Nebr., Nickel Engineering, 211 p.

Nowlin, W.H., Evarts, J.L., and Vanni, M.J., 2005, Release rates and potential fates of nitrogen and phosphorus from sediments in a eutrophic reservoir: Freshwater Biology, v. 50, no. 2, p. 301-322, [Also available at https://doi. org/10.1111/j.1365-2427.2004.01316.x.]

Nürnberg, G.K., 1988, Prediction of phosphorus release rates from total and reductant-soluble phosphorus in anoxic lake sediments: Canadian Journal of Fisheries and Aquatic Sciences, v. 45, no. 3, p. 453-462, [Also available at https:// doi.org/10.1139/f88-054.]

Olrik, K., Blomqvist, P., Brettum, P., Cronberg, G., Eloranta, P., 1998, Methods for quantitative assessment of phytoplankton in freshwaters, part I: Swedish Environmental Protection Agency, Report 4860.

Ott, R.L., and Longnecker, M., 2001, An introduction to statistical methods and data analysis (5th ed.): Pacific Grove, Calif., Duxbury Press, 1,152 p. 
Paerl, H.W., and Otten, T.G., 2013, Harmful cyanobacterial blooms: causes, consequences, and controls: Microbial Ecology, v. 65, no. 4, p. 995-1010. [Also available at https://doi.org/10.1007/s00248-012-0159-y.]

Penn, M.R., Auer, M.T., Doerr, S.M., Driscoll, C.T., Brooks, C.M., and Effler, S.W., 2000, Seasonality in phosphorus release rates from the sediments of a hypereutrophic lake under a matrix of $\mathrm{pH}$ and redox conditions: Canadian Journal of Fisheries and Aquatic Sciences, v. 57, no. 5, p. 10331041, [Also available at https://doi.org/10.1139/f00-035.]

Powers, S.M., Tank, J.L., and Robertson, D.M., 2015, Control of nitrogen and phosphorus transport by reservoirs in agricultural landscapes: Biogeochemistry, v. 124, nos. 1-3, p. 417-439, [Also available at https://doi.org/10.1007/ s10533-015-0106-3.]

Redfield, A.C., Ketchum, B.H., and Richards, F.A., 1963, The influence of organisms in the composition of sea-water, in Hill, M.N., eds., The sea-The composition of sea-water comparative and descriptive oceanography: New York, Interscience, The Sea-Ideas and Observations on Progress in the Study of the Seas Series, vol. 2, p. 26-77.

Rice, E.W., Baird, R.B., Eaton, A.D., Clesceri, L.S., eds., 2012, Standard methods for the examination of water and wastewater (22d ed.): Washington, D.C., American Public Health Association, American Water Works Association, Water Environment Federation, 1,496 p.

Rosenberg, N.J., Blad, B.L., and Verma, S.B., 1983, Microclimate-The biological environment ( $2 \mathrm{~d}$ ed.): New York, John Wiley and Sons, $495 \mathrm{p}$.

Runkel, R.L., Crawford, C.G., and Cohn, T.A., 2004, Load estimator (LOADEST) - A FORTRAN program for estimating constituent loads in streams and rivers: U.S. Geological Survey Techniques and Methods, book 4, chap. A5, 69 p. [Also available at https://pubs.usgs.gov/tm/2005/ tm $4 \mathrm{~A} 5 /$.

Schwab, G.O., Fangmeier, D.D., Elliot, W.J., and Frevert, R.K., 1993, Soil and water conservation engineering (4th ed.): John Wiley and Sons, $507 \mathrm{p}$.

Smith, V.H., and Schindler, D.W., 2009, Eutrophication science: where do we go from here?: Trends in Ecology \& Evolution, v. 24, no. 4, p. 201-207. [Also available at https://doi.org/10.1016/j.tree.2008.11.009.]

Søndergaard, Martin, Jensen, J.P., and Jeppesen, Erik, 2001, Retention and Internal Loading of Phosphorus in Shallow, Eutrophic Lakes: The Scientific World, v. 1, p. 427-442, [Also available at https://doi.org/10.1100/tsw.2001.72.]
Song, K., Adams, C.J., and Burgin, A.J., 2017, Relative importance of external and internal phosphorus loadings on affecting lake water quality in agricultural landscapes: Ecological Engineering, v. 108, pt. B, [Also available at https:// doi.org/10.1016/j.ecoleng.2017.06.008.]

Spalding, R., Snow, D., Burbach, M., Cassada, D., Unger, S., Toavs, J., Papiernik, T., and Burbach, K., 1992, Maskenthine Lake and Willow Creek, Nebraska-Phase I Diagnostic Assessment: University of Nebraska Water Center, Open File Report 92-2, 66 p.

Stanton, J.S., Peterson, S.M., and Fienen, M.N., 2010, Simulation of groundwater flow and effects of groundwater irrigation on stream base flow in the Elkhorn and Loup River Basins, Nebraska, 1895-2055-Phase two: U.S. Geological Survey Scientific Investigations Report 2010-5149, 78 p. with app. [Also available at https://pubs.usgs.gov/ sir/2010/5149/.]

Steffen, M.M., Belisle, B.S., Watson, S.B., Boyer, G.L., and Wilhelm, S.W., 2014, Status, causes and controls of cyanobacterial blooms in Lake Erie: Journal of Great Lakes Research, v. 40, no. 2, p. 215-225, [Also available at https:// doi.org/10.1016/j.jglr.2013.12.012.]

U.S. Department of Agriculture, 2014, 2011 national land cover dataset (NLCDS): Fort Worth, Tex., U.S. Department of Agriculture, digital data, accessed December 18, 2015, at https://gdg.sc.egov.usda.gov/.

U.S. Environmental Protection Agency, 2013, Method 353.2Determination of nitrate-nitrite nitrogen by automated colorimetry: Cincinnati, Ohio, U.S. Environmental Protection Agency, $15 \mathrm{p}$.

U.S. Geological Survey, variously dated, The national field manual for the collection of water-quality data: U.S. Geological Survey Techniques of Water-Resources Investigations, book 9, chaps. A1-A9. [Also available at https://pubs. water.usgs.gov/twri9A.]

U.S. Geological Survey, 2015, USGS water data for the Nation: U.S. Geological Survey National Water Information System database, accessed December 2015 at https://doi. org/10.5066/F7P55KJN.

Wagner, R.J., Boulger, R.W., Jr., Oblinger, C.J., and Smith, B.A., 2006, Guidelines and standard procedures for continuous water-quality monitors-Station operation, record computation, and data reporting: U.S. Geological Survey Techniques and Methods, book 1, chap. D3, 51 p. plus 8 attachments [Also available at https://pubs.usgs.gov/ $\mathrm{tm} / 2006 / \mathrm{tm} 1 \mathrm{D} 3 /$.

Welch, E.B., and Cooke, G.D., 1995, Internal Phosphorus Loading in Shallow Lakes: Importance and Control: Lake and Reservoir Management, v. 11, no.3, p. 273-281, [Also available at https://doi.org/10.1080/07438149509354208] 
Wetzel, R.G., 2001, Limnology (3d ed.): San Diego, Academic Press, 1,006 p.

Whiles, M.R., Brock, B.L., Franzen, A.C., and Dinsmore, S.C., II, 2000, Stream invertebrate communities, water quality, and land-use patterns in an agricultural drainage basin of northeastern Nebraska, USA: Environmental Management, v. 26 , no. 5 , p. 563-576, [Also available at https://doi. org/10.1007/s002670010113.]

YSI Incorporated, 2011, 6-series multiparameter water quality sondes user manual (revision H): Yellow Springs, Ohio, YSI Incorporated, $377 \mathrm{p}$. 



\section{Appendix}




\section{Appendix 1. Development of Stream Nutrient Load Models}

LOADEST (Runkel and others, 2004) is a program that estimates constituent loads based on predicted concentrations and user-supplied flow values. LOADEST develops linear regression equations for nutrient concentrations based on user-supplied flow and sample concentration data. The user can select the regression equation form or concentration, $C$, or allow the program to optimize model fit to supplied data. For this study, linear regression equations were optimized based on streamflow, time of year, and seasonality. The regression equation form was:

$$
\begin{aligned}
C= & a_{0}+a_{1} \ln Q+a_{2} \sin (2 \pi \text { dtime }) \\
& +a_{3} \cos (2 \pi \text { dtime })+a_{4} \text { dtime }
\end{aligned}
$$

where

$$
\begin{gathered}
C \quad \text { is nutrient concentration, in milligrams per } \\
\text { liter; } \\
a_{n} \quad \begin{aligned}
\text { are model coefficients; } \\
\ln Q
\end{aligned} \quad \begin{aligned}
\text { is the natural logarithm of the volumetric } \\
\text { streamflow rate }(Q), \text { in cubic feet per } \\
\text { second; }
\end{aligned} \\
\text { dtime is the center of decimal time. }
\end{gathered}
$$

Models were developed for three streamgage sites (Willow Creek near Foster [Foster], North Tributary to Willow Creek Lake [NT], and South Tributary to Willow Creek Lake [ST]) for four nutrients each (nitrate plus nitrite as nitrogen, total Kjeldahl nitrogen, total phosphorus, and phosphate as phosphorus). Nutrient data were collected and analyzed as described in the "External Nutrient Loading" section. Models were developed using the data analyzed at Midwest Laboratories, Inc. (Hall and others, 2018). Model coefficients are given in table 1.1. All models were evaluated for residuals normality using the probability plot correlation coefficient ( $p$-value) statistic calculated as part of LOADEST output. Two models had $p$-values less than the normality threshold of 0.05 (total phosphorus and phosphate as phosphorus for the NT site) and, after graphical investigations of the model fit and residuals, those models were retained as the best available model. 


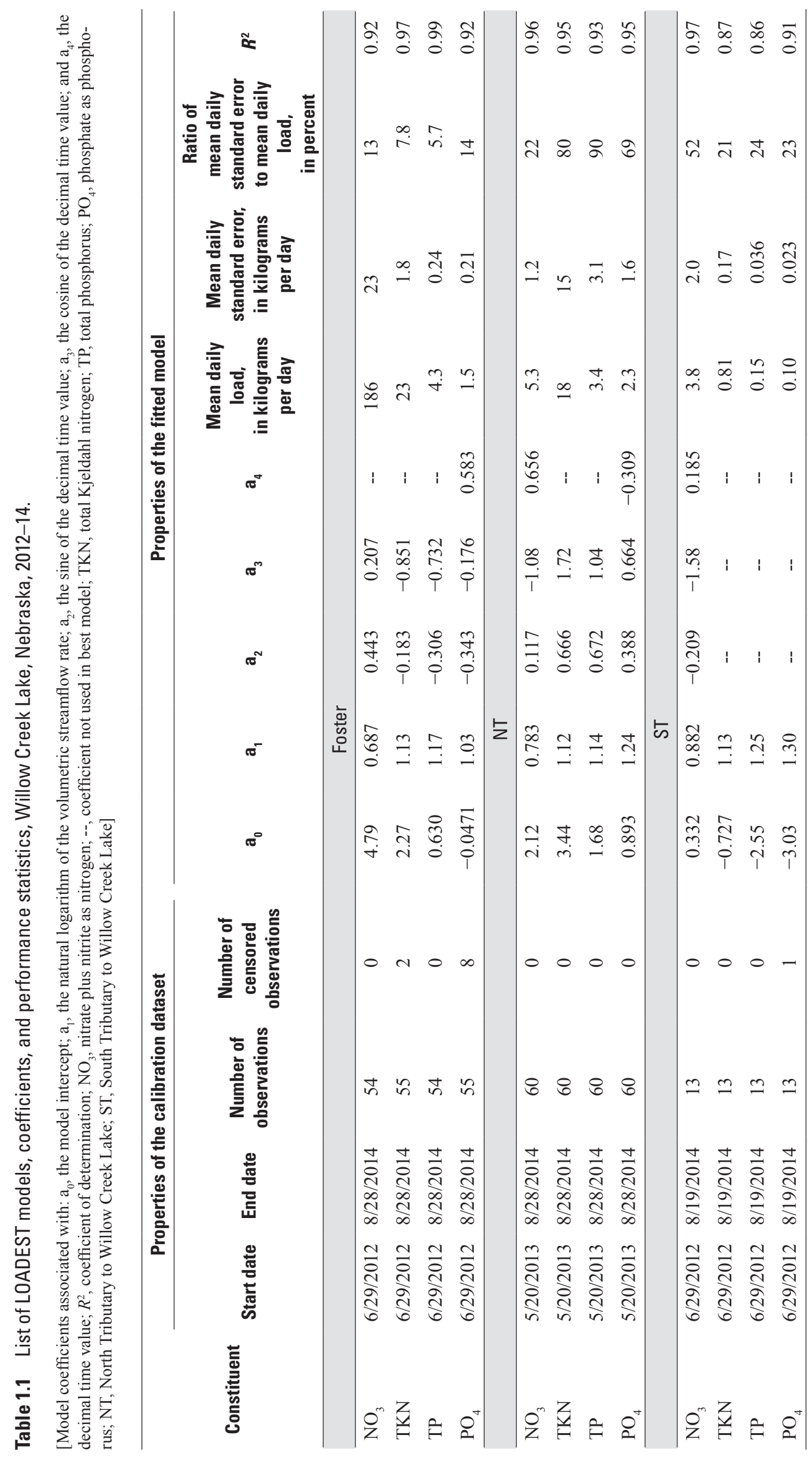


For more information about this publication, contact:

Director, USGS Nebraska Water Science Center

5231 South 19th Street

Lincoln, NE 68512

402-328-4100

For additional information, visit: https://www.usgs.gov/centers/newater

Publishing support provided by the

Rolla Publishing Service Center 



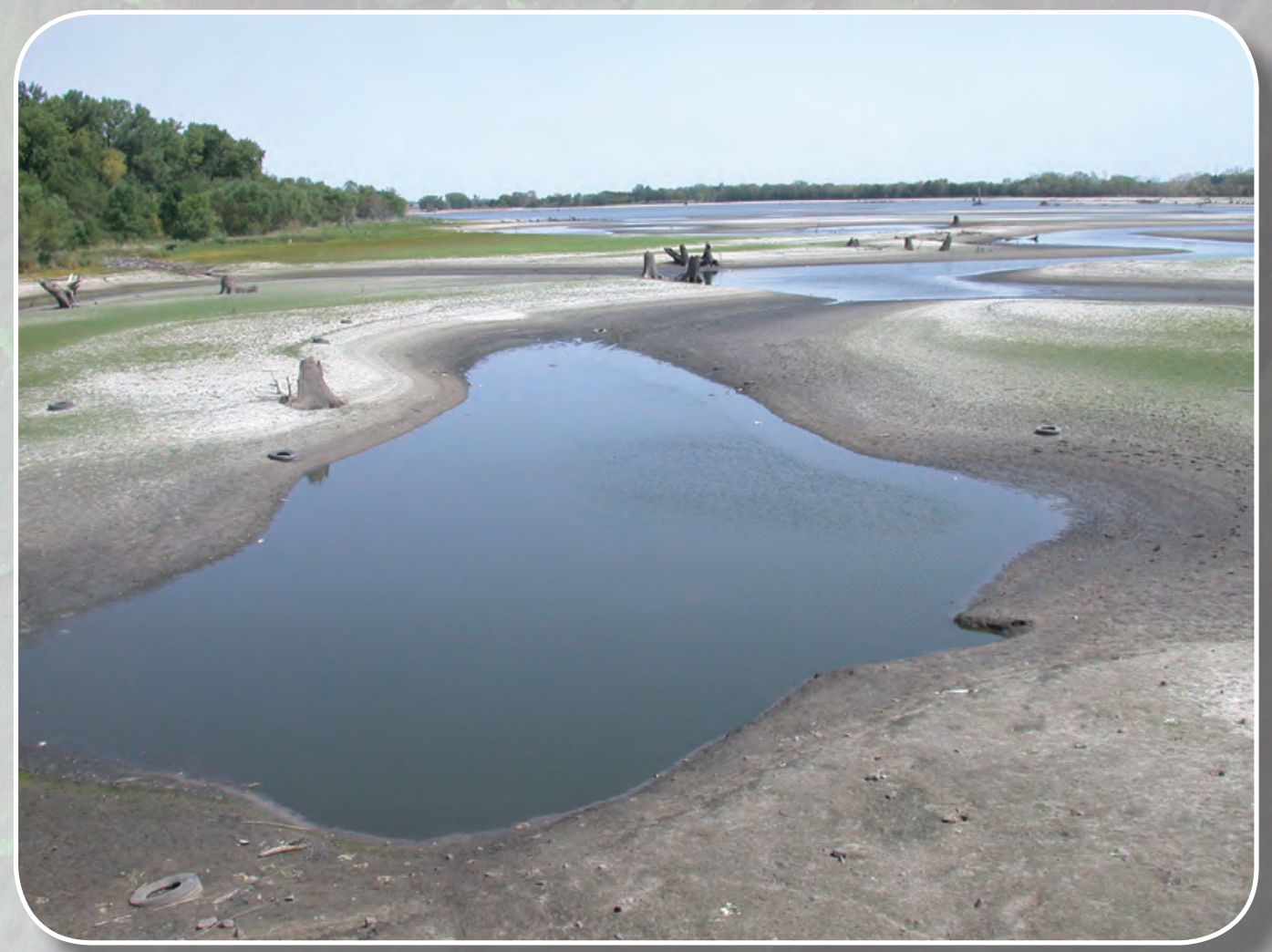

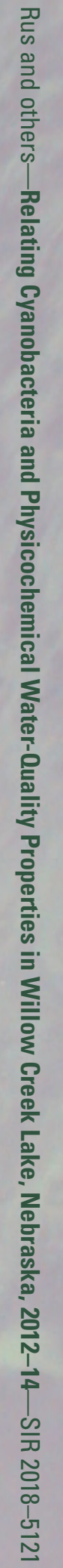

